\title{
Cell biology of retinoids in cancer : the modulating role of liarozole-fumarate
}

Citation for published version (APA):

van Van heusden, J. (1998). Cell biology of retinoids in cancer : the modulating role of liarozole-fumarate. [Doctoral Thesis, Maastricht University]. Universiteit Maastricht. https://doi.org/10.26481/dis.19980219jh

Document status and date:

Published: 01/01/1998

DOI:

10.26481/dis.19980219jh

Document Version:

Publisher's PDF, also known as Version of record

\section{Please check the document version of this publication:}

- A submitted manuscript is the version of the article upon submission and before peer-review. There can be important differences between the submitted version and the official published version of record.

People interested in the research are advised to contact the author for the final version of the publication, or visit the DOI to the publisher's website.

- The final author version and the galley proof are versions of the publication after peer review.

- The final published version features the final layout of the paper including the volume, issue and page numbers.

Link to publication

\footnotetext{
General rights rights.

- You may freely distribute the URL identifying the publication in the public portal. please follow below link for the End User Agreement:

www.umlib.nl/taverne-license

Take down policy

If you believe that this document breaches copyright please contact us at:

repository@maastrichtuniversity.nl

providing details and we will investigate your claim.
}

Copyright and moral rights for the publications made accessible in the public portal are retained by the authors and/or other copyright owners and it is a condition of accessing publications that users recognise and abide by the legal requirements associated with these

- Users may download and print one copy of any publication from the public portal for the purpose of private study or research.

- You may not further distribute the material or use it for any profit-making activity or commercial gain

If the publication is distributed under the terms of Article $25 \mathrm{fa}$ of the Dutch Copyright Act, indicated by the "Taverne" license above, 
Cell biology of retinoids in cancer 


\section{Cell biology of retinoids in cancer the modulating role of liarozole-fumarate}

Proefschrift

ter verkrijging van de graad van doctor

aan de Universiteit Maastricht,

op gezag van de Rector Magnificus.

Prof. Dr. A.C. Nieuwenhuijzen Kruseman.

volgens het besluit van het College van Decanen.

in het openbaar te verdedigen

op donderdag 19 februari 1998 om 14.00 uur

door

Jimmy Van heusden

geboren op 27 april 1971 te Wilrijk 


\section{Promotores:}

Prof. dr. M. Borgers

Prof, dr. F.C.S. Ramaekers

\section{Co-promotor:}

Dr. G. Smets (Janssen Research Foundation, Beerse, België)

\section{Beoordelingscommissie:}

Prof. dr. H.A.J. Struijker Boudier (voorzitter)

Prof. dr. M.P. van Dieijen-Visser

Prof. dr. R.A. Janknegt

Prof. dr. M. Mareel (Universiteit Gent, België)

Dr. P.T. van der Saag (NIOB, Utrecht)

The investigations described in this thesis were carried out at the Janssen Research Foundation, Beerse, Belglum.

This study was financially supported by the Janssen Research Foundation. 
Voor mijn ouders

Voor Danny

Voor Inge 
Van heusden, Jimmy

Cell biology of retinoids in cancer

The modulating role of liarozole-fumarate

Proefschrift Maastricht.

ISBN 90-9011343-6

Vormgewing: Danny Van heusden

Onnslagillustratie: Danny Van heusden

Druk: JAP Advertising 


\section{Contents}

General introduction

Liarozole potentiates the all-trans-retinoic acid-induced structural remodelling in human breast carcinoma MCF-7 cells in vitro.

Eur. J. Cell Biol. 71: 89-98, 1996.

Liarozole-fumarate potentiates the all-trans-retinoic acidinduced differentiation of $\mathrm{F} 9$ teratocarcinoma cells by inhibition of the all-trans-retinoic acid catabolism.

Submitted for publication.

Fluorescein-labeled tyramide strongly enhances the detection of low bromodeoxyuridine incorporation levels.

J. Histochem. Cytochem. 45: 315-319. 1997. 
All-trans-retinoic acid metabolites significantly inhibit the proliferation of MCF-7 human breast cancer cells in vitro.

Br. J. Cancer, in press.

The antiproliferative activity of all-trans-retinoic acid catabolites and isomers is differentially modulated by liarozolefumarate in MCF-7 human breast cancer cells.

$\mathrm{Br}$. J. Cancer, in press.

General discussion

Summary

Samenvatting

Dankwoord

Curriculum vitae 


\section{Abbreviations}

\begin{tabular}{|c|c|}
\hline APL & acute promyelocytic leukemia \\
\hline ATRA & all-trans-retinolic acid \\
\hline BrdU & 5-bromo-2"deoxyuridine \\
\hline CARD & catalyzed reporter depasition \\
\hline CHAPS & 3-[(3-cholamidopropyl)-dimethylammonio]-1-propane sulfonate \\
\hline CRABP & cellular retinoic acid binding protein \\
\hline CRBP & cellular retinol binding protein \\
\hline DAPI & 4'-6-diamidine 2-0-phenylindole \\
\hline DCC-FBS & dextran-coated charcoal-treated fetal bovine serum \\
\hline DMEM & Dulbecco's modified Eagle's medium \\
\hline $\mathrm{DR}$ & direct repetition \\
\hline ELISA & enzyme-linked immunosorbent assay \\
\hline FBS & fetal bovine serum \\
\hline FITC & fluorescein isothiocyanate \\
\hline HPLC & high-performance liquid chromatography \\
\hline HRP & horseradish peroxidase \\
\hline IEE & isoelectric focusing \\
\hline LRAT & lecithin:retinol acyltransferase \\
\hline MTT & 3-(4.5-dimethy] thiazol-2-yl)-2,5-diphenyl-2H-tetrazolium bromide \\
\hline N-CAM & neural-cellular adhesion molecule \\
\hline NADPH & reduced form of B-nicotinamide adenine dinucleotide phosphate \\
\hline PBS & phosphate buffered saline \\
\hline PI & propidium iodide \\
\hline PLL & poly-L-lysine \\
\hline PPAR & peroxisome proliferator-activated receptor \\
\hline PSA & prostate specific antigen \\
\hline $\mathrm{RA}$ & retinoic acid \\
\hline RalDH & retinal dehydrogenase \\
\hline RAR & retinolc acid receptor \\
\hline RARE & retinoic acid responsive element \\
\hline RBP & retinol-binding protein \\
\hline REH & retinyl ester hydrolase \\
\hline RoDH & retinol dehydrogenase \\
\hline $\mathrm{RT}$ & room temperature \\
\hline $\mathrm{RXR}$ & retinoid $\mathrm{X}$ receptor \\
\hline SEM & standard error of the mean \\
\hline S.E.M. & scanning electron microscopy \\
\hline $\mathrm{SD}$ & standard deviation \\
\hline SDS & sodium dodecyl sulfate \\
\hline $\mathrm{TR}$ & thyroid hormone receptor \\
\hline Tris & Tris(hydroxymethyl)-aminomethane \\
\hline TSA & tyramide signal amplification \\
\hline TTR & transthyretin \\
\hline VDR & vitamin $\mathbb{D}$ receptor \\
\hline
\end{tabular}





\section{General introduction}

Retinoids are a group of natural and synthetic compounds that share structural and/or functional similarity to vitamin A. Vitamin A (retinol) has long been recognized as an indispensable nutrient, playing a central role in many biological processes such as vision. reproduction, and immune function. Besides retinoids are well-known to modulate cellular growth and differentiation. Therefore it is not surprising that retinoids are being evaluated for use in the treatment of cancer, aiming at reversing the process of malignancy by inducing differentiation and inhibiting uncontrolled growth. All-trans-retinoic acid (ATRA), a metabolite of vitamin $A$, is probably the most potent naturally occurring retinoid. Clinical successes with ATRA in differentiation therapy are however limited. One explanation for this limited success is the rapid emergence of resistance to the drug, believed to result from increased ATRA catabolism. Inhibitors of ATRA catabolism might therefore prove valuable in the treatment of cancer. 


\section{Retinoid sources and metabolism}

The major dietary sources of retinol (Fig. 1) are carotenoids from fruits and vegetables, and retinyl esters from animal food (Olson. 1989: Blomhoff et al. 1992). Of the carotenoids, Bcarotene is the most potent precursor of retinol (Blomhoffet al., 1992). In the small intestine. B-carotene enters the enterocytes by passive diffusion where it is mainly converted to retinal (Lakshman et al, 1989) through central cleavage by the enzyme B-carotenoid-15.15"dioxygenase (Olson, 1989). Retinal binds to cellular retinol binding protein II (CRBP II) and is then reduced to retinol by a rnicrosomal retinal reductase (Kakkad and Ong, 1988). CRBP II also binds retinol that is derived from retinyl esters by hydrolysis in the intestinal lumen (Blomhoff et al., 1992). CRBP II-bound retinol is further converted by the enzyme lecithin: retinol acyltransferase (LRAT) back to retinyl esters which are packaged into nascent chylomicrons (lipoprotein particles). In the lymphatic system, chylomicrons undergo Jypolysis to give rise to chylomicron remnants. The chilomicron remnants are taken up by the hepatic parenchymal cells (Blomhoff et al. 1992). Here, the retinyl esters undergo a

SMALE WNTESTINE

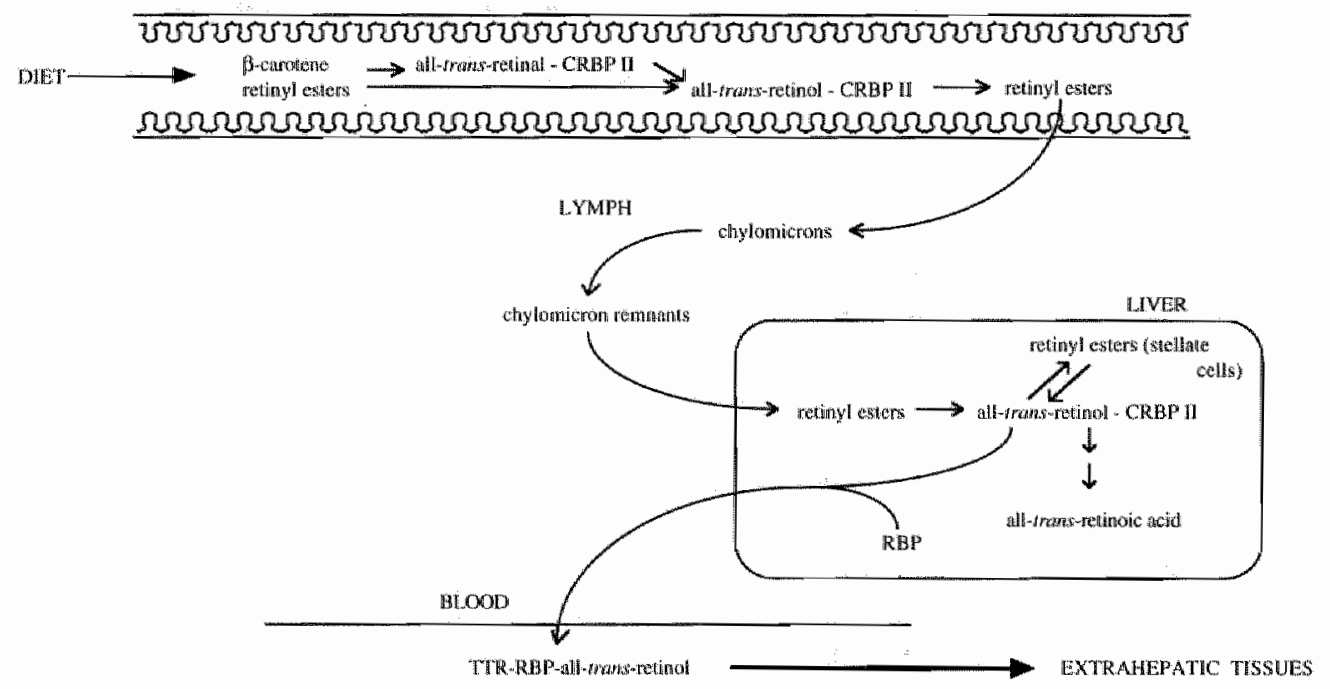

Figure 1: Schematic representation of retinoid uptake, transport, storage and metabolism. CRBP, cellular retinol binding protein; RBP, retinol-binding protein; TTR, transthyretin (adapted from Napoli, $\| 996$, see text for details). 
cycle of hydrolysis and re-esterification before storage in the stellate cells. When needed the stored retinyl esters are hydrolyzed to retinol and secreted from the liver in association with retinol-binding protein (RBP). In the blood plasma, RBP-retinol complexes to transthyretin (TTR) and serves as a source of retinoid for extrahepatic tissues. Also extrahepatic tissues have been shown to play a significant and important role in the storage and mobilization of retinol. As such they may contribute to vitamin A homeostasis (Soprano and Blaner, 1994).

\section{Tissue uptake of retinol}

The mechanism by which retinol is taken up by target cells remains to be elucidated (Soprano and Blaner, 1994). At least in some cells, a receptor for RBP has been described (Blomhoff $e t$ al. 1991: Dew and Ong, 1994). Despite the attractiveness of such a model for receptormediated uptake of retinol, it has been reported that holo-RBP spontaneously and rapidly dissociates to RBP and retinol (Noy and Xu, 1990a, 1990b). The free retinol would then be available for cellular uptake by non-specific mechanisms. It has been postulated by Noy and Blaner (1991) that the quantity of apo-CRBP, present in the target cell, determines the amount of retinol that is taken up by the cell.

\section{Intracellular metabolism of retinol to retinoic acid (RA)}

Once inside the cell, retinol can be either stored as retinyl esters or converted to RA. RA is now recognized as a major, but not the exclusive, physiological active metabolite of retinol. The different steps involved in its formation have so far not been unequivocally established. Many tissues and cells possess the ability to convert retinol into RA (Napoli, 1994). Figure 2 illustrates a model, as proposed by Napoli (1996). for RA biosynthesis and catabolism and stresses the involvement of retinoid binding proteins. In this model, the ratio apo-CRBP/ holo-CRBP determines the flux of retinol to RA or to retinyl esters (Napoli, 1996). CRBPbound retinol serves as a substrate for a family of microsomal retinol dehydrogenases (RoDH)(Posch er al., 1991) that catalyze the conversion to retinal. Retinal remains bound to CRBP and is oxidized irreversibly to RA. This conversion involves cytosolic retinal dehydrogenases (RalDH) (Posch et al., 1992), although several cytochrome P450-dependent enzymes also have been shown to catalyze this reaction (Raner et al. 1996). RA binds to cellular RA binding protein (CRABP) and is further metabolized (see below). 


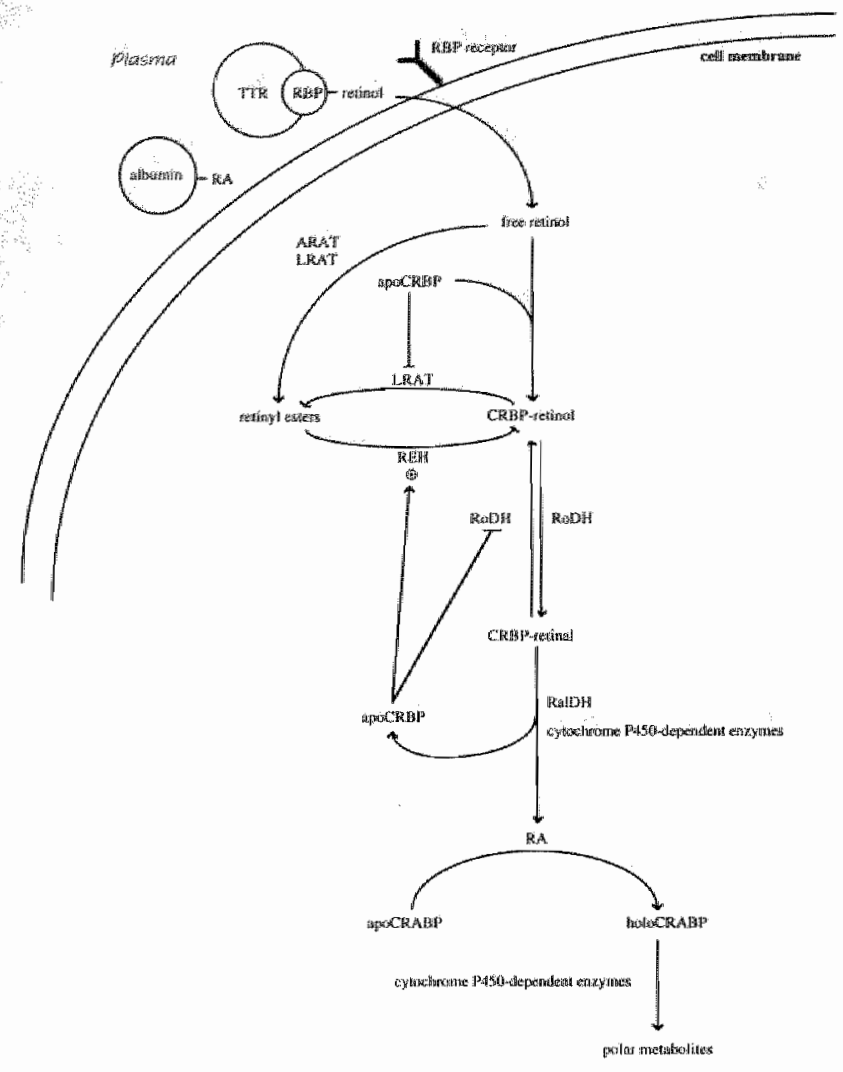

Figure 2: A model proposed for the biosynthesis of ATRA from retinol. ARAT, acyl COA:retinol acyltransferase; CRABP, cellular RA binding protein; CRBP, cellular retinal binding protein; $R A$, retinoic acid; $R B P$, retinolbinding protein; $\mathrm{REH}$, retinyl ester hydrolase: TTR, transthyretin: LRAT, lecithin:retinol acyltransferase; RaIDH, retinal dehydrogenase; RoDH, retinol dehydrogenase (adapted from Napoli, 1996, see text for details).

\section{Other sources of RA}

RA can also orliginate from eccentric cleavage of B-carotene (Wang et al. 1992; Parker, 1996). Another possibility is that RA is present in trace quantities in the diet or is formed in small quantities in the intestine. RA circulates in blood bound to serum albumin and as such can serve as a source of RA for several tissues (Smith et al., 1973; Kurlandsky et al. 1995). The molecular mechanisms for RA uptake into the cell are not clear.

\section{ATRA: metabolism and mechanism of action}

ATRA has been shown to control cell growth and differentiation in a number of cell types. The responses elicited by ATRA are however very diverse. It has only recently become clear how a relatively simple molecule like ATRA can elicit such a diversity of biological responses. 


\section{ATRA metabolism and isomerization}

Diversity in the action of ATRA exists because of complexity at different levels of the ATRA signalling pathway. A first and important level in this complex ATRA signalling pathway is represented by the existence of natural isomers and metabolites of ATRA, whose synthesis may be modulated in a cell-specific fashion (De Luca, 1991: Leid et al., 1992: Keaveny and Stunnenberg, 1995: Chambon, 1996: Napoli, 1996). Naturally occurring isomers and metabolites of ATRA (Fig. 3) include 13-cis-RA (Eckhoff et al., 1991; Tang and Russell, 1990), 9-cis-RA (Heyman et al. 1992; Levin et al. 1992), 9,13-dicis-RA (Tzimas et al. 1994a: Sass et al., 1995), 4-hydroxy-ATRA (Skare et al. 1982), 4-oxo-ATRA (Eckhoff et al., 1991; Tang and Russell. 1991). 18-hydroxy-ATRA (Hänni and Bigler. 1977; Fiorella and Napoli. 1994), 3.4didehydro-ATRA (Thaller and Eichele, 1990). 5.6-epoxy-ATRA (McCormick et al., 1978: Barua et al., 1991), and retinoyl-B-glucuronide (Barua and Olson, 1986: Barua et al., 1991: Eckhoff et al. 1991).

Figure 3: Chemical stiructures of naturally occurring metabolites and isomers of ATRA.
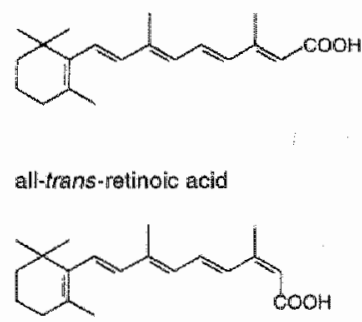

13-cis-metinoic acid

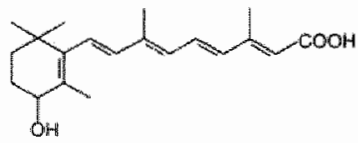

4-hydroxy-all-tans-retinoic acid<smiles>CC(/C=C/C1=C(CO)CCCC1(C)C)=C\C=C\C(C)=C\C(=O)O</smiles>
18:hydroxy-all-trans-relline ic abid<smiles>CC(/C=C/C12OC1(C)CCCC2(C)C)=C\C=C\C(=O)O</smiles>

5,6-epoxy-all-frans-retincaic acid

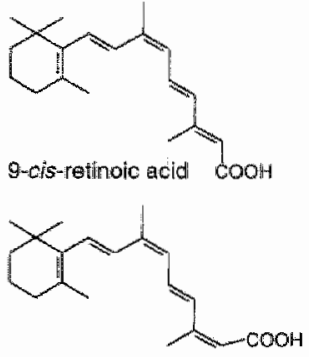

9, 13 -dil cis-retinoic acid<smiles>CC1=C(/C=C/C(C)=C/C=C/C(C)=C/C(=O)O)C(C)(C)CCC1=O</smiles>

4-0xo-allntrans-petinoic acid<smiles>CC1=C(/C=C/C(C)=C/C=C/C(C)=C/C(=O)O)C(C)(C)CC=C1</smiles>

3,4-didehydro-all-trangimetimolic acio<smiles>CC1=C(/C=C/C(C)=C/C=C/C(C)=C/C(=O)OC2(O)OC(C(=O)O)C(C)C(O)C(O)C2O)C(C)(C)CCC1O</smiles>

retinoyl $-\beta 2$ glucuronide 


\section{Oxidation}

The oxidative metabolism of ATRA to more polar metabolites has been known for some time. However, it was not until the advent of high-performance liquid chromatography (HPLC) that this topic could be investigated in detail. Hänni and Bigler (1977) identified two metabolites of ATRA in rat faeces as 4-oxo-ATRA and 18-hydroxy-ATRA. McCormick et al. (1978) identified 5.6-epoxy-ATRA as a metabolite of ATRA in the intestinal mucosa of vitamin A-deficient rats, and Frolik et al. (1978, 1979) identified both 4-hydroxy-ATRA and 4-oxoATRA as metabolites of ATRA in the hamster trachea in organe culture and in subcellular fractions of the liver. Roberts et al. (1980) studied the metabolism of ATRA in hamster liver microsomes. It was shown that ATRA is first converted to 4-hydroxy-ATRA, which is then converted to 4-oxo-ATRA and further catabolized to more polar metabolites. The formation of 4-hydroxy-ATRA and the further catabolism of 4-oxo-ATRA were found to require NADPH. In addition, the enzymatic activity was found to be mainly present in the microsomal fraction. shown to require oxygen, and was strongly inhibited by carbon monoxide. Together, these findings suggested the participation of cytochrome P450-dependent enzyme(s) in ATRA catabolism (Roberts et al., 1979a, 1979b, 1980).

A number of cytochrome P450-dependent enzymes have been shown to be capable of 4-hydroxylating ATRA (Table I). Purified cytochromes P4502C7 and P450 2B1 from rat liver microsomes were shown to catalyze the conversion of ATRA to polar metabolites. including 4-hydroxy-ATRA (Leo et al., 1984). The P4502C8 isoform from human liver microsomes can oxidize ATRA to 4-hydroxy-ATRA and 4-oxo-ATRA (Leo et al., 1989) and, in addition, can also convert retinol into 4-hydroxy-retinol. Many cytochrome $\mathrm{P} 450$ isoforms, including 2B4, IA2, 2E1,2E2, 2C3, 2G1, and 3A6, from rabbit liver microsomes catalyze the 4-hydroxylation of ATRA, with the isoforms $1 \mathrm{~A} 2$ and 2B4 being the most potent ones (Roberts et al., 1992). A member of the cytochrome P450 3A subfamily has also been implied in the 4-hydroxylation of ATRA (Martini and Murray. 1993). Although these findings demonstrate that a number of purified cytochrome $\mathrm{P} 450$-dependent enzymes are able to catalyze the 4-hydroxylation of ATRA, the characterization of the ATRA 4-hydroxylase at the molecular level was achieved only very recently. White et al. (1996) cloned a cytochrome P450dependent enzyme from zebrafish, namely P450RAl, that was strongly induced by ATRA. P450RAl was shown to catalyze the conversion of ATRA to 4-hydroxy-ATRA and 4-oxo-ATRA. It seems that its human counterpart is highly homologous, indicating a conserved role in ATRA catabolism (White et al. 1996). 
Table I: Cytochrome P450-dependent ATRA 4-hydroxylases

\begin{tabular}{llll}
\hline isozyme & species & tissue & reference \\
\hline $2 \mathrm{~B} 1,2 \mathrm{C} 7$ & rat & liver & Leo et al. (1984) \\
$2 \mathrm{C} 8$ & human & liver & Leo et al. (1989) \\
$1 \mathrm{~A} 2,2 \mathrm{~B} 4$ & rabbit & liver & Roberts et al. (1992) \\
$3 \mathrm{~A}$ & rat & liver & Martini and Murray (1993) \\
P450RAI & zebrafish & fins & White et al. (1996) \\
\hline
\end{tabular}

Other pathways by which ATRA may be oxidized is via epoxidation to 5.6-epoxy-ATRA (McCormick et al. 1978; Barua et al., 1991) and hydroxylation to 18-hydroxy-ATRA (Hänni and Bigler, 1977: Fiorella and Napoli. 1994; Han and Choi, 1996). The significance of these pathways in the catabolism of ATRA remains to be established.

\section{Isomerization}

ATRA readily undergoes isomerization. Pharmacological doses of ATRA isomerize to 13 cisRA in rats (Cullum and Zile, 1985: Napoli et al. 1985; Kojima et al., 1994) and mice (Kalin et. al. 1981). Conversely, 13-cis-RA was found to isomerize to ATRA (Puglisi and DeSilva, 1978; Kalin et al., 1982; Vane et al., 1982; McCormick et al., 1983). Also in human serum 13-cisRA has been identified (Tang and Russell, 1990; Eckhoff $e t a l ., 1991$ ) and isomerization of ATRA to 13-cis-RA and vice versa has been reported (Goodman et al. 1982: Muindi et al. . 1994: Takitani et al., 1995). The existence of 9-cis-RA was reported by Levin et al. (1992) and Heyman et al. (1992). In rats. ATRA isomerizes to 9-cis-RA to a limited extent (Rojima et al. 1994), while in mice and rats 9-cis-RA isomerizes to ATRA, 13-cis-RA and 9.13-dicis-RA (Tzimas et al., 1994a). In man, isomerization of 9-cis-RA into ATRA was observed to only a limited extent (Sass et al. 1995) and 9.13-dicis-RA has not been identified. Isomerization of ATRA into 9-cis-RA and 13-cis-RA, and vice versa, occurs non-enzymatically (Shih et al, 1986: Urbach and Rando, 1994: Shih et al. 1997).

\section{Glucuronidation}

The free carboxyl group of ATRA is important for its biological activity. The only known naturally occurring derivative where the carboxyl group is blocked is retinoyl-B -glacuronide (Barua and Olson, 1986). B-Glucuronides of retinol, 13-cis-RA, 9-cis-RA, 4-oxo-RA and 5.6- 
epoxy-RA have also been identified Napoli et al. 1982: Eckhoff et al. 1991. Creech Kraft et al., 1991a, $199 \mathrm{lb}$, Sass et al. 1994). Unlike other ATRA derivatives, retinoyl-B-glucuronide is water soluble and is considered a product of detoxification. Retinoyl-B-glucuronide is biologically active (Zile et al. 1987: Janick-Buckner et al., 1991, Mehta et al. 1991) but could not be demonstrated to bind to cellular retinoid binding proteins or nuclear receptors (Mehta et al. 1992: Sani et al. 1992). It seems that its activity is derived from the hydrolysis to ATRA (Tzimas et al., 1994b: Foerster et al., 1996; Nau et al., 1996).

\section{Cellular RA binding proteins (CRABPs)}

Another level that adds to the complexity of RA signalling is the existence of cellular RA binding proteins, CRABPs (Ong et al. 1994: Li and Norris, 1996). Both isoforms of CRABP. CRABPI and CRABPII, bind RA with high affinity. There is a strong preference for ATRA over the other RA isomers and CRABPI binds ATRA with higher affinity than does CRABPII. suggesting that they may have different functions. Natural metabolites of ATRA, including 4-hydroxy-ATRA, 4-oxo-ATRA, 18-hydroxy-ATRA and 3,4-didehydro-RA, can also bind to CRABPs (Fiorella er al. 1993). Binding of 9-cis-RA occurs with much lower affinity. There is little, if any detectable binding of 13-cis-RA and 9.13-dicis-RA to either isoform of CRABP (Ong et al., 1994; Li and Norris, 1996). The function of CRABPs is not clear. It has been proposed that CRABPs sequester ATRA in the cytoplasm. functioning as a buffer system to limit the availability of ATRA to its nuclear receptors (Boylan and Gudas, 1991). Besides. CRABPs have been suggested to transport ATRA from the cytoplasm to the nucleus (Takase at al. 1986: Gustafson et al. 1996). Furthermore. CRABPs have also been shown to facilitate ATRA catabolism (Ong et al., 1994: Li and Norris, 1996). However, the physiological importance of CRABP-facilitated catabolism was recently challenged by showing that CRABPI null mutant mice had a normal phenotype (de Bruijn et al., 1994; Gorry et al. 1994). Also CRABPII null mutant mice did not exhibit any overt phenotypic defects (Fawcett et al.. 1995: Lampron et al, 1995). Double mutant mice for both CRABPI and CRABPII were also essentially normal (Lampron et al., 1995). Moreover, these null mutant mice did not show increased sensitivity to RA. It has been suggested that CRABPs may function in maintaining physiological levels of intracellular ATRA under conditions of limited supply of vitamin A. The exact function of CRABPs thus remains as yet elusive. 


\section{Nuclear retinoid receptors}

It is now well established that ATRA signals are mediated by nuclear retinoid receptors. Two families of retinoid receptors exist. Le. the RA receptors (RARs) and the retinoid $\mathrm{X}$ receptors (RXRs), which are structurally and functionally related to the menbers of the nuclear receptor superfamily (Mangelsdorf et al, 1995). This superfamily also includes receptors for steroids, thyroid hormone, and vitamin D (Mangelsdorf et al, 1995; Chambon. 1996) as well as a number of "orphan receptors" for which specific ligands have not yet been identified. Each retinoid receptor family consists of three subtypes, i.e. $\alpha$. B, and $\gamma$, encoded by separate genes located on different chromosomes (Chambon. 1996). Each subtype can occur as different isoforms as a result of differential promotor use and alternative splieing. The major difference between RARs and RXRs lies in their ligand binding potential. In addition to ATRA and 9-cis-RA. RARs also bind ATRA metabolites including 4-oxo-ATRA (Pijnapppel et al., 1993; Kim et al, 1994; Chambon, 1996). The ability of the natural stereoisomer 13-cis-RA to bind to RARs is still controversial (Åström et al., 1990; Crettaz et al., 1990; Matsushima et al. 1992; Repa et al. 1993; Huggenvik and Sharma. 1995). On the contrary, RXRs only bind 9-cis-RA (Heyman et al., 1992; Levin et al. 1992). In contrast to the receptors for steroid hormones, which bind to DNA as homodimers, the retinoid receptors interact with DNA as heterodimers. RARs can only dimerize with RXR. RXR serves as a heterodimer partner for the thyroid hormone receptor (TR), the vitamin D receptor (VDR), the peroxisome proliferator-activated receptor (PPAR), and a number of orphan receptors, e.g. NURR1. NGFIB, and LXR (PFahl and Chytil. 1996). In addition, RXR can also function as a homodimer in the presence of 9-cis-RA (Zhang et al. 1992). The unique capability of RXRs to form homodimers in response to 9-cis-RA and the ability of RXR to form heterodimers with a number of other nuclear receptors. suggest that RXRs act as important regulators in the cross talk among retinoids and other hormones.

Upon ligand-binding, the RXR/RAR heterodimer functions as a transcription factor (Fig. 4) that transactivates gene expression by binding to short DNA sequences known as RAresponsive elements (RARE)(Leid et al. 1992; Mangelsdorf et al. 1994: Keaveny and Stunnenberg. 1995: Chambon, 1996). RAREs are located in the promotor-region of a large number of RA target genes, such as for example RARs and laminin B1. Most RARE consist of the direct repetition (DR) of two core consensus hexamer sequences (A/G)G(T/G)TCA separated by a number of nucleotides. RXR/RAR heterodimers bind DR spaced by 1 (DR1), 2 (DR2) or 5 (DR5) nucleotides with increasing efficiency (Chambon. 1996). It has been established that RXR/RAR heterodimers bind DR with a certain polarity (Fig, 4)(Glass, 1996). 
Indeed, RXR binds the 5'-upstream hexameric sequence while RAR binds the 3-downstream hexamer half site on DR2 and DR5. Furthermore, on DR1 the RXR/RAR heterodimer can also bind with the reverse polarity i.e. with RXR occupying the 3 "-downstream hexamere 15 "RAR/RXR-3). Unlike most other members of the nuclear receptor superfamily, RARs are able to suppress transcription of RA target genes in the absence of ligand binding. The polarity of binding (Fig. 4) to the DR determines the transactivation or transrepression potential of the RXR/RAR heterodimer. The transactivator/repressor function of RXR/RAR heterodimers is further fine tuned by a family of coactivators and corepressors (Horwitz et al. 1996).

A large number of retinoid responsive genes have been identified, but the specific mechanisms by which retinoids affect cellular growth and differentiation have not been fully elucidated in any model system.

In conclusion, the complex RA signalling pathway is explained by the existence of various naturally occurring RA metabolites, which can undergo a number of conversions, the existence of several CRABPs, nuclear retinoid receptors, response elements, coactivators and corepressors.

TRANSACTIVATION
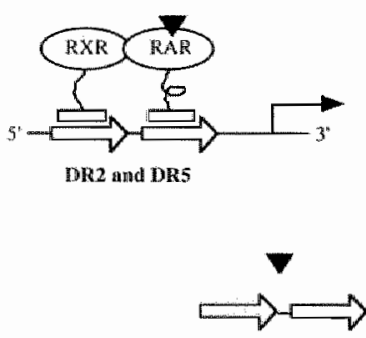

TRANSREPRESSION

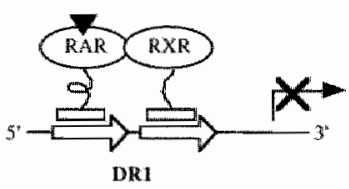

all-mans-retroic ancid

direce nepent:

Figure 4: Schematic representation of RAR/RXR transactivation and transrepression.

\section{Retinoids, cancer and differentiation therapy}

Cancer is characterized by abnormal growth and a derailment of differentiation. Besides, it has also been well established that retinoids are able to inhibit cell proliferation and induce differentiation in a large number of cell types. Therefore, it is not surprising that retinoids have been extensively explored for potential use in cancer chemoprevention and therapy. 
The aim of therapy with retinoids, also known as differentiation therapy, is to arrest or reverse the process of malignancy to a more "normal" phenotype by the induction of differentiation (Scott. 1997).

\section{Biological activity of ATRA}

In vitro, retinoids and more particularly ATRA have been demonstrated to inhibit cell proliferation of both normal and malignant cells (Lotan, 1980; Amos and Lotan. 1990). In addition. in some cell types. ATRA was able to induce terminal differentiation that was accompanied by a loss of neoplastic character. The induction of terminal differentiation was most striking in human HL-60 promyelocytic leukemia cells (Breitman er al., 1980; Strickland et al. 1983), and in mouse F9 teratocarcinoma cells (Strickland and Mahdavi, 1978: Strickland and Sawey, 1980). In HL-60 cells, ATRA induced differentiation of promyelocytes to mature granulocytes, concomitant with growth inhibition. In F9 teratocarcinoma cells. ATRA induced differentiation to a variety of cell lineages depending on the culture conditions used (Strickland and Mahdavi, 1978; Strickland et al., 1980" Hogan et al. 1981; Rogers et al. 1990). Recently, it has also been recognized that retinoids induce programmed cell death (apoptosis), but little is known about the mechanisms involved (Kalemkerian and Ramnath, 1996).

Also in vivo the usefullness of retinoids has been extensively demonstrated (Moon et al.. 1994). In animal models, retinoids were highly effective in inhibiting the process of carcinogenesis and in chemoprevention (Moon et al., 1994). Furthermore, epidemiological studies have reported that a low intake of vitamin $\mathrm{A}$ is correlated with a higher tumor incidence (Hong and Itri, 1994: Lotan, 1996). Taken together, these data indicate a potential role of retinoids in the treatment and prevention of human cancer.

\section{ATRA: clinical results}

By far the most encouraging results have been obtained in patients with acute promyelocytic leukemia (APL) (Meng-er et al., 1988: Castiagne et al., 1990; Chen et al. 1991: Smith et al. 1992; Warrell et al., 1991). ATRA treatment resulted in complete remissions in a large number of patients. In addition, some of these studies showed that the remissions were due to induction of differentiation of promyelocytes to mature pollymorphonuclear leukocytes. Besides the beneficial effect of ATRA in APL patients, only limited success has been obtained in epithelial cancers.

13-cis-RA showed efficacy in the treatment of premalignant oral leukoplakia (Hong et al. 
1986) and in the prevention of second primary tumors in patients with head and neck cancer (Hong et al., 1990). On the contrary, RA was not effective in the treatment of most primary solid cancers. including squamous cell carcinoma of the head and neck. lung and malignant melanoma (Hong and Itri. 1994). To improve the clinical effectiveness of retinoids. combination therapy with interferons has been used (Lippman et al., 1997). This kind of combination therapy has been shown valuable in the treatment of squamous cell carcinoma of the skin (Lippman et al., 1992a) and cervix (Lippman et al., 1992b). In conclusion. retinoids have so far shown only limited success and ongoing clinical trials will have to establish their potential use in cancer therapy. Furthermore, the clinical use of ATRA is significantly hampered by its toxicity and the prompt emergence of ATRA resistance.

\section{Toxicity}

Drug toxicity is a major problem in ATRA therapy. Low doses of ATRA are usually well tolerated by adults, but at higher doses general signs of toxicity, also known as hypervitaminosis A. become evident. Major side effects influencing the quality of life include cheilitis. mucocutaneous reactions, manifesting as erythema, rash, and desquamation, and headache (Lee et al.. 1993). The limited success of ATRA therapy may in part be explained by the fact that the toxicity of high doses of ATRA limits its therapeutic use.

\section{Resistance}

As already mentioned. ATRA therapy has been shown highly effective in the treatment of patients with APL. However, clinical remissions are usually short-lived because most patients relapse due to the prompt emergence of ATRA resistance (Castaigne et al., 1990; Warrell et al. 1993; Lazzarino et al., 1996). Several pharmacokinetic studies have shown that the plasma concentration of ATRA, with continuous dosing, progressively declines, suggesting that ATRA induces its own catabolism (McPhillips et al., 1987; Muindi et al., 1992a, 1992b. 1994; Smith et al. 1992; Rigas et al. 1993). This phenomenon was also observed in patients with solid tumors (Lee et al., 1993: Muindi et al., 1994). Furthermore, the autoinduction of catabolism was not observed with chronic dosing of 13-cis-RA (Brazell et al. 1983) or 9-cisRA (Adamson et al., 1995; Miller et al.. 1996). One approach to overcome ATRA resistance is the development of compounds that are able to inhibit the catabolism of ATRA. Such inhibitors would be able to maintain high ATRA levels despite the presence of increased catabolism. 


\section{Liarozole-fumarate, an inhibitor of ATRA catabolism}

Liarozole fumarate (Fig. 5). a new antitumor drug, has been identified as an inhibitor of the cytochrome P450-dependent catabolism of ATRA (Van Wauwe et al, 1990. 1992. Wouters et al. 1992; Krekels ot al., 1996, 1997).

In vitro. liarozole-fumarate by itself has no effect. but in combination with ATRA the drug enhances the biological activity of this retinoid. In MCF-7 human breast cancer cells, liarozolefumarate enhanced the antiproliferative activity of ATRA by 10-fold (Wouters et al., 1992). Under basal growth conditions, MCF-7 cells were unable to catabolize ATRA. but the ATRA catabolism could be induced rapidly by pretreatment with ATRA (Wouters et al, 1992: Krekels et al. 1997). This resulted in its conversion to more polar metabolites, as shown by HPLC (Wouters et al., 1992). Liarozole-fumarate was able to inhibit this induced ATRA catabolism with an $\mathrm{IC}_{50}$ value of $440 \mathrm{nM}$. resulting in a decreased amount of polar metabolites (Wouters et al. 1992; Krekels et al., 1997). Thus, the enhancement by liarozole-fumarate of the antiproliferative activity of ATRA in MCE-7 cells was most probably due to inhibition of ATRA catabolism. In F9 mouse teratocarcinoma cells, which are known to have an active ATRA catabolism (Williams and Napoli, 1985, 1987). liarozole-fumarate was also able to enhance the activity of ATRA on the induced expression of plasminogen activator (De Coster et al., 1992).

In addition, the activity of ATRA and B-carotene on cellular transformation and gap junctional communication was potentiated in 10T1/2 mouse embryonal fibroblasts (Acevedo and Bertram, 1995) and retinoid-induced apoptosis was enhanced in DU145 human prostate cancer cells (Hall, 1996).

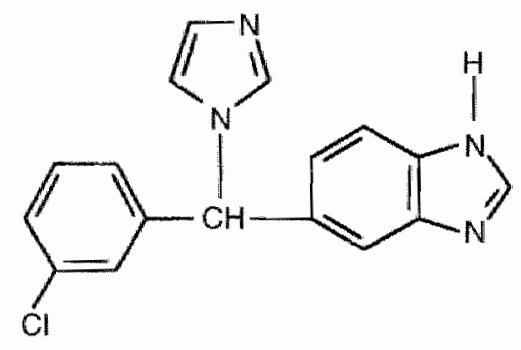<smiles>O=C(O)C=CC(=O)O</smiles>

Figure 5: Chemical structure of liarozole-fumarate $\{ \pm-5-[(3-$ chloropheny $)(1 \mathrm{H}$. imidazole- $|-y|)$ methyl]-|H-benzimidazole (E)-2-butenedioate $(2: 3)\}$. 


\section{Chapter 1}

In vivo, liarozole-fumarate increased the biological half-life of exogenously injected ATRA in rats (Van Wawwe et al. 1990) and of orally administered ATRA and 13-cis-RA in cancer patients (Westarp et al., 1993: Achkar et al., 1994; Miller et al., 1994). Moreover, liarozole-fumarate was able to enhance endogenous ATRA levels (Van Wauwe et al., 1990; Smets et al., 1995). thereby mimicking similar morphological and biochemical effects on rat vaginal epithelium as observed after RA treatment (Van Wauwe et al., 1992). These retinoid-mimetic effects of liarozole-fumarate could be explained by its inhibition of ATRA catabolism (Van Wauwe $e t$ al. 1992).

The antitumoral activity of liarozole-fumarate was investigated in several rat Dunning R3327 prostate adenocarcinoma sublines. The drug reduced tumor growth in both androgendependent, sublines $G$ and $H$. and androgen-independent. sublines PIF-1 and AT-6, prostate tumors (Van Ginckel et al., 1990: Dijkman et al., 1994; Smets et al., 1995). In the Dunning AT6sq subline, it was shown that liarozole-fumarate increased endogenous ATRA levels both in plasma and in the tumor (Smets et al., 1995). Concomitantly, a shift in the differentiation status was noticed which was further confirmed by a strong decrease in cytokeratin 10, a typical ATRA-linked phenomenon (Smets et al., 1995). Tumor homogenates of the Dunning $G$ subline were shown to have an active ATRA catabolism, that could be inhibited by liarozolefumarate (Krekells et al., 1996). Also the subcutaneous and bone metastatic tumor growth of androgen-independent PC-3ML-B2 human prostate cancer cells was inhibited by liarozolefumarate in severe combined immunodeficient mice (Stearns et al., 1993). Taken together. these findings suggested that the antiproliferative activity of liarozole-fumarate was related to its potential to inhibit ATRA catabolism.

In clinical trials, liarozole-fumarate has been evaluated in advanced prostate cancer patients (Boccardo et al. 1994: Mahler et al., 1994: Wouters, 1994: Seidmon et al., 1995: Bryson and Wagstaff, 1996). In some patients with measurable disease a partial response was observed. as determined by regression of soft-tissue metastasis. Because measurable disease is rare, prostate specific antigen (PSA) was regarded as the most suitable alternative in the followup of advanced prostate cancer patients (Mahler et al., 1994). Liarozole-fumarate induced a $\geq 50 \%$ decrease of PSA levels in about 30\% of unselected patients (Mahler et al., 1994; Bryson and Wagstaff, 1996).

A number of patients experienced less bone pain and most patients showed side effects similar to hypervitaminosis A. reinforcing the hypothesis that liarozole-fumarate exerts its effects by inhibiting ATRA catabolism and thereby accumulating the endogenous ATRA levels. 


\section{Aim of this study}

ATRA is well known to inhibit the proliferation of cancer cells. This antiproliferative activity of ATRA could be enhanced by liarozole-fumarate, an inhibitor of ATRA catabolism. Besides; ATRA is also known to induce differentiation in cancer cells. The first objective was to test the possibility that liarozole-fumarate could also enhance the differentiation-inducing capacity of ATRA. To test this hypothesis. the structural remodelling induced by ATRA was studied by immunocytochemistry in the presence of liarozole-fumarate.

The second objective was to develop an in vitro model system in which cells could be grown in the absence of endogenous retinoids in order to study the effect of catabolism on the antiproliferative activity of ATRA and its metabolites. In addition, the mechanism of action of liarozole-fumarate was further investigated in light of its potential role in cancer therapy.

\section{References}

Acevedo, P., and Bertram. I.S. Liarozole potentiates the cancer chemopreventive activity of and the up-regulation of gap junctional communication and connexin 43 expression by retinoic acid and B-carotene in 10T1/2 cells. Carcinogenesis 16:2215-2222, 1995.

Achkar, C.C., Bentel. J.M., Boylan, J.F. Scher H.I. Gudas, L., and Miller, W.H.Jr. Differences in the pharmacokinetic properties of orally administered all-trans-retinoic acid and 9-cis-retinoic acid in the plasma of nude mice. Drug Metab. Dispos. 22: 451-458, 1994.

Adamson, P.C., Murphy, R.F., Godwin, K.A., Ulm, E.H., and Balis, E.M. Pharmacokinetics of 9-cisretinoic acid in the rhesus monkey. Cancer Res, 55: 482-485. 1995.

Amos, B., and Lotan, R. Retinoid-sensitiwe cells and cell lines. Methods Enzymol. 190:217-225, 1990.

Åström. A., Pettersson. U., Krust. A. Chambon. P, and Voorhees. J.1. Retinole acid and synthetic analogs differentially activate retinoic acid receptor dependent transcription. Biochem. Biophys. Res. Cornmun. 173: 339-345, 1990.

Barua, A.B., and Olson. J.A. Retinoyl-B-glucuronice: an endogenous compound of human blood. Am. 1. Clin. Nutr. 43:481-485, 1986

Barua, A.B., Gunning, D.B., and Olson. J.A. Metabolism in wivo of all-trans-[11. $\left.{ }^{3} \mathrm{H}\right]$ retinoic acid after an oral dose in rats. Biochem. J, 277: 527.531. 1991 .

Blomhoff, R., Green, M.H., Green, J.B., Berg, T." and Norwm, K.R. Vitamin A metabolism: new perspectives on absorption, transport, and storage. Physiol. Rev. $11: 951-990,1991$,

Blomhoff, R., Green, M.H., and Norum, K.R. Vitamin A: physiologtcal and biochemical processing. Annu. Rev. Nutr. 12: 37-57, 1992. 
Boccardo. F, Cannata, D. Guameri, D., Oneto, F., Cortesi, E., and Bono. A. R75251 in prostate cancer pattents in progression after first-line hormonal treatment. Tumori 80: 276-279. 1994.

Boylan, J.F., and Gudas, L.). Overexpression of the cellular retinoic acid binding protein-I (CRABP-I) results in a reduction in differentiation-specific gene expression in $\mathrm{F} 9$ teratocarcinoma cells. J. Cell. Biol. 112:965-979. 1991

Brazell, R,K, Vane, F.M. Ehmann, C.W., and Colburn. W.A. Pharmacokinetics of isotretinoin during repetitive dosing to patients. J. Clin. Pharmacol. 24:695-702. 1983.

Breitman. T.R., Selonick, S.E., and Collins, S.J. Induction of differentiation of the human promyelacytic leukemia cell line (HL-60) by retinoic acid. Proc. Natl. Acad. Sci. U.S.A. 77: 2936-2940. 1980.

Bryson, H.M., and Wagstaff. A.ग. Liarozole. Drugs \& Aging 9: 478-484, 1996.

Castaigne, S., Chomuienne, $C$., Daniel, M.T., Ballerini, P. Berger R., Fenaux, P, and Degos, L. Alltrans-retinoic acid as a differentiation therapy for acute promyelocytic leukemia. I. Clinical results. Blood 76: 1704-1709. 1990.

Chambon, P. A decade of molecular biology of retinoic acid receptors. FASEB J. 10; 940-954, 1996.

Chen, Z.-X., Xue, Y.-Q. Zhang, R., Tao, R.-F., Xia, X.-M., Wang, W., Zu, W.Y., Yao, X.-Z., and Ling, B.-J. A clinicall and experimental study on all-trans-retinoic acid treated acute promyelocytic leukemia patients. Blood 78: 1413-1419, 1991.

Creech Kraft, J., Eckhoff, C., Kochhar, D.M., Bochert, G. Chahoud, L., and Nau, H. Isotretinoin (13-cisretinoic acid) metabolism, cis-trans isomerization, glucuronidation and transfer to the mouse embryo: Consequences for teratogenicity. Teratogen. Carcinogen. Mutagen. 11:21-30, 199.1a.

Creech Kraft, I.. Slikker, W.Jr., Bailey, J.R., Roberts, L.G., Fischer, B., Wittfoht, W., and Nau, H. Plasma pharmacokinetics and metabolism of 13-cis-and all-trans-retinoic acid in the cynomolgus monkey and the identification of 13-cis-and all-trans-retinoyl-B-glucuronides. A comparison to one human case study with isotretinoin. Drug Metab. Dispos. 19: 317-324. 1991 b.

Crettaz, M. Baron, A., Siegenthaller, G., and Hunziker, W. Ligand specificities of recombinant retinoic acid receptors RAR $\alpha$ and RARR. Biochem. J. 272: 391-397, 1990.

Cullum. M.E. and Zile. M.H. Metabolism of all-trans-retinoic acid and all-trans-retinyl acetate. Demonstration of common physiological metabolites in rat small intestinal mucosa and circulation. II. Biol. Chem, 260; 10590-10596, 1985.

de Bruijn, D.R.H., Oerlemans, F., Hendriks. W.. Baats. E.. Ploemacher, R., Wieringa, B., and Geurts van Kessel A. Normal development, growth and reproduction in cellular retinoic acid binding proteinI (CRABP.I) null mutant mice. Differentiation 58: 141-148. 1994.

De Coster, R., Wouters, W., Van Ginckel, R., End, D. Krekels, M., Coene, M.-C., and Bowden, C. Experimental studies with liarozole (R 75251): an antitumoral agent which inhibits retinoic acid breakdown. J. Steroid Biochem. Mol. Biol. 43: 197-201, 1992. 
De Luca, L.M. Retinoids and their receptors in differentiation, embryogenesis, and neoplasia. IASEB I. $5: 2924-2933,1991$.

Dew, S.E., and Ong, D.E. Specificity of the retinol transporter of the rat small intestine brish border. Biochemistry 33: 12340-12345, 1994.

Dijkman, G.A., Van Moorselaar, R.J.A., Van Ginckel, R., Van Stratum, R., Wouters, L., Debruyne, F.M..... Schalken, J.A., and De Coster, R. Antitumoral effects of liarozole in androgen-dependent and independent R3327-Dunning prostate adenocarcinomas. J. Urol. 151: 217-222, 1994.

Eckhoff, C. Collins, M.D., and Nau. H. Human plasma all-trans-13-cis-and 13-cis-4-oxo-retinoic acid profiles during subchronic vitamin A supplementation: Comparison to retinol and retinyl ester plasma levels. J. Nutr. 121: 1016-1025, 1991.

Fawcett, D., Pasceri. P., Fraser. R., Colbert. M., Rossant, J., and Giguère, V. Postaxial polydactylly in forelimbs of CRABP-II mutant mice, Development 121:671-679, 1995.

Fiorella, P.D., Giguère, V., and Napoli, J.L. Expression of cellular retinoic acid-binding protein (Type II) in Escherichia coli. J. Biol. Chem. 268: 21545-21552, 1993.

Fiorella, P.D., and Napoli. J.L. Microsomal retinoic acid metabolism. Effects of cellular retinoic acidbinding protein (Type I) and C18-hydroxylation as an initial step. J. Biol. Chem. 269: 1053810544, 1994.

Foerster. M.. Sass. J.O., Rühl. R., and Nau. H. Comparative studies on effects of all-trans-retinoic acid and all-trans-retinoyl-13-glucuronide on the development of fetal mouse thymus in an organ culture system. Toxicol. In Vitro 10: 7-15, 1996.

Frolik, C.A., Tavela. T.E., Newton, D.L., and Sporn, MB. In vitro metabolism and biological activity of all-trans-retinoic acid and its metabolites in hamster trachea. J. Biol. Chem. 253: 7319-7324, 1978.

Frolik, C.A., Roberts, A.B., Tavela, T.E., Roller, P.P., Newton, D.L., and Sporn, M.B. Isolation and identification of 4-hydroxy-and 4-oxo-retinoic acid. In vitro metabolites of all-trans-retinoic acid in hamster trachea and liver. Biochemistry 18: 2092-2097. 1979.

Glass. C.K. Some new twists in the regulation of gene expression by thyroid hormone and retinoic acid receptors. J. Endocrinol. 150: 349-357, 1996.

Goodman, G.E., Einspahr, J.G., Alberts, D.S., Davis, T.P. Leigh, S.A., Chen, H.S.G., and Meyskens, F.L. Pharmacokinetics of 13-cis-retinoic acid in patients with advanced cancer. Cancer Res. 42: 2087. $2091,1982$.

Gorry. P. Lufkin. T., Dierich. A., Rochette-Egly, C., Décimo, D., Dollé, P., Mark, M., Durand, B., and Chambon. P. The cellular retinoic acid binding protein I is dispensable. Proc. Natl. Acad. Sci. U.S.A. $91:$ : $9032-9036,1994$. 
Gustafson, A.L., Donovan. M. Annerwall, E, Dencker, Li, and Eriksson, U. Nuclear import of cellular retinoic acid-binding protein type I in mouse embryonic cells. Mech. Dew. 58: 27-38, 1996.

Hall, A.K Liarozole amplifies retinoid-induced apoptosis in human prostate cancer cells. Anti-Cancer Drugs $7: 312-320,1996$.

Han. IS., and Choi. J.-H. Highly specific cytochrome P450-like enzymes for all-trans-retinoic acid in T47D human breast cancer cells. J. Clif. Endocrinol Metab. 81: 2069-2075. 1996.

Hänni, R, and Bigler, $F$. Isolation and identification of three major metabolites of retinoic acid from rat feces. Helv. Chim. Acta 60:881-887, 1977.

Heyman, R.A., Mangelsdorf, D.J., Dyck, J.A., Stein, R. Euchele, G., Evans, R.M., and Thaller, C. 9-cisRetinoic acid is a high affinity ligand for the retinoid $X$ receptor. Cell 68: 397-406, 1992.

Hogan, B.L.M. Taylor, A, and Adamson, E. Cell interactions modulate embryonal carcinoma cell differentiation into parietal or visceral endoderm. Nature (London) 291: 235-237, 1981.

Hong, W.K, and Itri "L.M. Retinoids and human cancer. In: Sporn, M.B., Roberts, A.B., Goodman, D.S. (eds.). The Retinoids. Blology, Chemistry and Medicine, Ed. 2. pp. 597-630. New York Raven Press, Ltd.. 1994

Hong. W.K., Endicott, J. Itri, L.M., Doos, W., Batsakis, ],G., Bell, R., Fofonoff, S., Byers. R. Atkinson, E.N., Vaughan, C., Toth, B.B., Kramer, A. Dimery, L.W., Skipper, P., and Strong, S. 13-cis-Retinoic acid in the treatment of oral leukoplakia. N. Eng. J. Med. 24: 1501-1505. 1986.

Hong, W.K: Lippman, S.M., Itri, L.M., Karp D.D. Lee, J.S. Byers, R.M., Schantz, S.P. Kramer, A.M., Lotan, R., Peters, L.J. . Dimery, I.W., Brown, B.W., and Goepfert. H. Prevention of second primary tumors with isotretinoin in squamous-cell carcinoma of the head and neck. N. Engl. J. Med. 12: 795-800. 1990.

Horwitz, K.B.. Jackson, T.A., Bain, D.L, Richer, J.K., Takimoto, G.S., and Tung, L. Nuclear receptor coactivators and corepressors. Mol. Endocrinol. 10: $1167-1177,1996$.

Huggenvik, J.I., and Sharma, R.P. Transcriptional activation of a model reporter system by retinoids and retinoic acid receptor isofiorms. Pharmacol. Toxicol. 76: 1,7-22, 1995.

Janick-Buckner. D., Barua, A.B., and Olson. J.A. Induction of HL-60 cell differentiation by watersoluble and nitrogen-containing conjugates of retinoic acid and retinol. FASEB j. 5: 320-325. 1991.

Kakkad, B., and Ong, D.E. Reduction of retinaldehyde bound to cellular tetinol-binding protein (type II) by microsomes from rat small intestine. J, Biol. Chem. 263:12916-12919, 1988.

Kalemkerian. G.P., and Ramnath, N. Retinoids and apoptosis in cancer therapy. Apoptosis 1: 11-24. 1996. 
Kalin, J.R. starling. M.E. and Hill D.L. Disposition of all-trans-retinoic acid in mice following oral doses. Drug Metab. Dispos. 9: 196-201. 1981.

Kalin, J.R. Wells, M.J, and Hill, D.L. Disposition of 13 -cis-retinoic acid and N-(2-hydroxyethyl) retinamide in mice following oral doses. Drug Metab. Dispos: 10: 391-398, 1982.

Keaveny, M., and Stunnenberg. H.G. Retinoic acid receptors. In: Batuerle, P.A. (ed.), Inducible Gene Expression, pp 187-242. Boston: Birkhäeuser, 1995.

Kim, Y.W., Sharma, R.P., and Li, J.K.K. Characterization of heterologously expressed recombinant retinoic acid receptors with natural or synthetic retinoids. J. Biochem. Toxicol. 9: 225-234, 1994.

Kojima, R., Fujimori, T., Kjyota, N., Toriya, Y., Fukuda, T., Ohashi, T., Sato, T., Yoshizawa, Y., Takeyama K.-I., Mano. H., Masushige, S., and Kato, S. In vivo isomerization of retinoic acids. Rapid isomer exchange and gene expression. J. Biol. Chem. 269: 32700-32707. 1994.

Krekels, M.D.W.G., Zimmerman, J. Janssens, B., Van Ginckel, R., Cools, W., Van Hove, C. Coene, M." C., and Wouters, W. Analysis of the oxidative catabolism of retinoic acid in rat Dunning R3327G prostate tumors. Prostate 29: 36-41, 1996.

Krekels, M.D.W.G., Verhoeven, A., van Dun, J., Cools, W., Van Hove, $C_{w}$ Dillen, L., Coene, M.-C., and Wouters, W. Induction of the oxidative catabolism of retinoic acid in MCF-7 cells. Br. J. Cancer 75: 1098-1104, 1997.

Kurlandsky, S.B., Gamble, M.V., Ramakrishnan, R., and Blaner, W.S. Plasma delivery of retinoic acid to tissues in the rat. J. Biol. Chem. 270: 17850-17857, 1995.

Lakshman, M.R. Mychkovski, I., and Attlesey, M. Enzymatic conversion of all-trans-B-carotene to retinal by a cytosolic enzyme from rabbit and rat intestinal mucosa. Proc. Natl. Acad. Sci. U.S.A. 86: $9124-9128,1989$.

Lampron, C. Rochette-Egly, C., Gorry. P., Dollé. P, Mark, M., Lufkin, T., LeMeur, M.; and Chambon, P. Mice deficient in cellular retinotc acid binding protein II (CRABPI) or in both CRABPL and CRABPII are essentially normal. Development 121:539-548. 1995.

Lazzarino, M., Regazzi. M.B., and Corso, A. Clinical relevance of all-trans-retinoic acid pharmacokinetics and its modulation in acute promyelocytic leukemia. Leukemia and Lymphoma 23: 539-543. 1996.

Lee. J.S., Newman. R.A., Lippman. S.M., Huber, M.H., Minor, T., Raber, M.N., Krakoff, I.H., and Konga W.K. Phase levaluation of all-trans-retinoic acid in adults with solid tumors. I. Clin. Oncol. 11: 959-966. 1993.

Leid, M. Kastner, P., and Chambon. P. Multiplicity generates diversity in the retinoic acid signalling pathways. Trends Biochem. Sci. 17: 427-433, 1992. 
Leo, M.A., Iida, S, and Lieber, C.S. Retinoic acid metabolism by a system reconstitued with cytochrome P450. Arch. Biochem. Biophys. 234: 305-312, 1984,

Leo, M.A., Lasker, J.M., Raucy, J.L., Kim. C-I., Black, M., and Lieber, C.S. Metabolism of retinol and retinoic acid by human liver cytochrome P450IIC8. Arch. Biochem. Biophys. 269: 305-312. 1989.

Levin, A.A., Sturzenbecker, L. ], Kazmer, S., Bosakowski, T, Huselton, C. Allenby, G., Speck, I., Kratzeisen, C.L., Rosenberger, M., Lovey, A., and Grippo. J.F. 9-cis-Retinoic acid stereotsomer binds and activates the nuclear receptor RXR- $\alpha$. Nature (London) 355: 359-361. 1992.

Li, E., and Norris, A.W. Structure/function of cytoplasmic vitamin A-binding proteins. Annu. Rev. Nutr. 16:205-234, 1996.

Lippman, S.M., Parkinson, D.R., Itri, L.M., Weber, R.S., Schantz, S.P., Ota, D.M. Schusterman. M.A." Krakoff, L.H., Gutterman, J.U., and Hong, W.K. 13-cis-retinoic acid and interferon $\alpha$-2a: effective combination therapy for advanced squamous cell carcinoma of the skin. J. Natl. Cancer Inst. 84: 235-241, $1992 a$.

Lippman, S.M., Kavanagh, J.J., Paredes-Espinoza, M., Delgadillo-Madrueno. F., Paredes-Casillas, P.. Hong. W.K., Holdener, E., and Krakoff, I.H. 13-cis-retinoic acid plus interferon $\alpha$-2a: highly active systemic therapy for squamous cell carcinoma of the cervix. I. Natl. Cancer Inst. 84: 241. 245. $1992 b$.

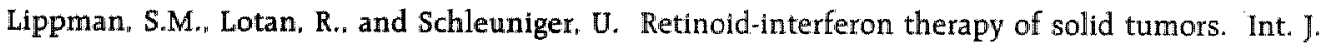
Cancer 70; 481-483, 1997.

Lotan, R. Effects of vitamin A and its analogs (retinoids) on normal and neoplastic cells. Biochim. Biophys. Acta 605: 33-91, 1980.

Lotan, R. Retinoids in cancer chemoprevention. FASEB J. 10: 1031-1039, 1996.

Mahler, C., Verhelst, J., Denis, L., De Porre, P., De Coster, R., Freyne, E., and Bruynseels, I. Liarozole Fumarate. Drugs Future 19:552-556, 1994.

Mangelsdorf, D.J., Umesono, K., and Evans, R.M. The retinold receptors. In: Sporn. M.B., Roberts, A.B., Goodman, D.S (eds.). The Retinoids. Biology. Chemistry and Medicine, Ed. 2, pp. 319-349. New York: Raven Press, Ltd. 1994.

Mangelsdorf, D.J." Thummel, C., Beato, M., Herrlich, P., Schütz, G., Umesono, K., Blumberg, B., Kastner. P., Mark, M., Chambon, P., and Evans, R.M. The nuclear receptor superfamily: the second decade. Cell 83: 835-839, 1995 .

Martini, R., and Murray, M. Participation of $15403 A$ enzymes in rat hepatic microsomal retinoic acid 4-hydroxylation. Arch. Biochem. Biophys. 303: 57-66, 1993.

Matsushima, Y., Kawachi, E., Tanaka, H., Kagechika, H., Hashimoto. Y., and Shudo, K. Differentiationinducing activity of retinoic acid isomers and their oxidized analogs on human promyelocytic leukemia HL-60 cells. Biochem. Biophys. Res. Commun. 189: 136-1142, 1992. 
McCormick. A.M. Napoll, y.L. Schnoes, H.K, and DeLuca. H.F. Isolation and identification of 5,6epoxy-retinoic acid: A biologically active metabolite of retinoic acid Blochemistry 17: 4085 $4090,1978$.

McCormick, A.M., Kroll, K.D., and Napoli. J.L. 13wcis-Retinoic acid metabolism in wito. The major tissue metabolites in the rat have all-trans configuration. Biochemistry 22:3933-3940, 1983.

McPhillips, M.D. Kalin. J.R. and Hill, D.L. The pharmacokinetics of all-trans retinoic acid and N-2hydroxyethyl)retinamide in mice as determined with a sensitive and convenient procedure. Drug Metab. Dispos. 15: 207-211,1987.

Mehta, R.G., Barwa, A.B., Olson, J.A., and Moon, R.C. Effects of retinoid glucuronides on mammary gland development in organ culture. Oncology 48:505-509, 1991 .

Mehta, R.G., Barua, A.B., Olson, J.A. and Moon, R.C. Retinoid glucuronides do not interact with retinoid binding proteins. Int. I. Vit. Nutr. Res. 62: 143-147, 1992.

Meng-er, H., Yu-Chen, Y., Shu-Rong, C., Jin-Ren, C. Jia-Xiang, L. Long-Jun, I, and Zhen-Y1, W. Use of all-trans-retinoic acid in the treatment of acute promyelocytic leukemia. Blood 72:567-572. 1988.

Miller, V.A., Rigas, J.R., Muindi, J.R.F. Tong, W.P., Venkatraman, E. Kris, M.G., and Warrell, R.P.Jr. Modulation of all-trans-retinoic acid pharmacokinetics by liarczole. Cancer Chemother. Pharmacol. 34: 522-526, 1994.

Miller, V.A., Rigas, J.R., Benedetti, F.M., Verret, A.L., Tong, W.P., Kris, M.G. Gill, G.M., Loewen, G.R., Truglia, J.A., Ulm, E.H., and Warrell, R.P.Jr. Initial clinical trial of the retinoid receptor pan agonist 9-cis-retinoic acid. Clin. Cancer Res. 2: 471-475, 1996.

Moon, R.C., Mehta, R.G., and Rao, K.V.N. Retinoids and cancer in experimental animals. In: Sporn, M.B., Roberts, A.B., Goodman, D.S. (eds.), The Retinoids. Biology, Chemistry and Medicine, Ed. 2. pp. 573-595. New York: Raven Press, Ltd. 1994.

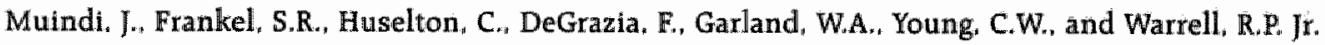
Clinical pharmacology of oral all-trans-retinoic acid in patients with acute promyelocytic leukemia. Cancer Res. 52: 2138-2142, 1992a.

Muindi, J., Frankel, S.R., Miller, W.H.Jr. Jakubowski, A., Scheinberg, D.A., Young, C.W., Dmitrovsky, E. and Warrell, R.P. Jr. Continuous treatment with all-trans-retinoic acid causes a progressive reduction in plasma drug concentrations: implications for relapse and retinold "resistance" in patients with acute promyelocytic leukemia. Blood 79:299-303,19926.

Muindi, J.F., Scher, H.I., Rigas. J.R., Warrell, R.P. Jr., and Young, C.W. Elevated plasma lipid peroxide content correlates with rapid plasma clearance of all-trans-retinoic acid in patients with advanced cancer. Cancer Res. 54: 2125-2128. 1994 


\section{Chapter 1}

Wapoli. J.L. Khalil, H, and McCormick. A. Metabolism of 5,6epoxyretinoic acid in vivo. isolation of a major intestinal metabolite. Bochemistry $21: 1942-1949.1982$.

Napoli. J.L., Pramanik, B.C. Williams, J.B., Dawson, M.I. and Hobbs. B.D. Quantification of retinolic acid by gas-liquid chromatography-mass spectrometry: Total versus all-trans-retinoic acid in human plasma. J. Lipid Res, 26: $387392,1985$.

Napoli. J.L. Retinoic acid Homeostasis. Prospective Roles of B-carotene, retinol, CRBP, and CRABP. In: Blomhoff. R. (ed.), Vitamin A in health and disease, pp. 135-188. New York: Dekker, 1994.

Napoli J.L. Biochemical pathways of retinoid transport metabolism, and signall transduction. Clin. Immund. Immunopathol. 80: S52-S62, 1996.

Nau, H., Elmazar, M.M.A., Rühl, R. Thiel, R., and Sass, J.O. All-trans-retinoyl-B-glucuronide is a potent teratogen in the mouse because of extensive metabolism to all-trans-retinoic acid. Teratology 54: $150-156,1996$.

Noy, N., and Xu. Z.-J. Interactions of retinol with binding proteins: Implications for the mechanism of uptake by cells. Biochemistry 29:3878-3883, 1990 a.

Noy, $N_{*}$ and $X u, Z$. - . The thermodynamic parameters of the binding of retinol to binding proteins and membranes. Blochemistry 29:3888-3892, 19906.

Noy, N., and Blaner. W.S. Interactions of retinol with binding proteins: studies with rat cellular retinolbinding protein and with rat retinol-binding protein. Blochemistry 30:6380-6386, 1991.

Olson, J.A. Provitamin A: function of carotenoids. J. Nutr. 119: 105-108, 1989.

Ong, D.E., Newcomer, M.E., and Chytil. F. Cellular retinoid-binding proteins. In: Sporn, M.B., Roberts. A.B.. Goodman. D.S. (eds.). The Retinoids. Biology. Chemistry and Medicine, Ed. 2. pp. 283-317. New York: Raven Press, Ltd., 1994.

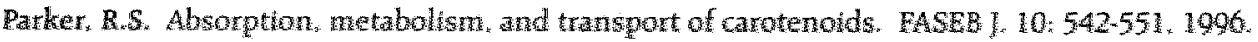

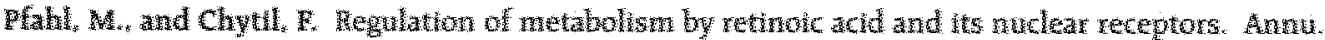

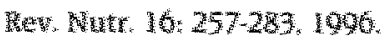

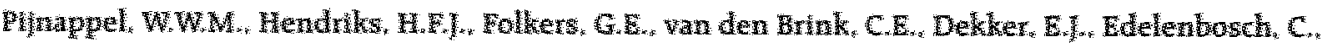

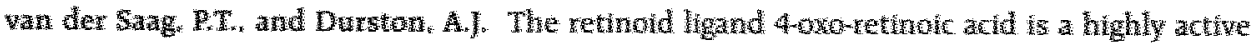

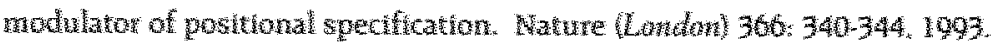

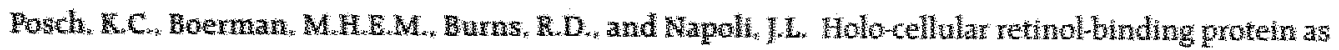

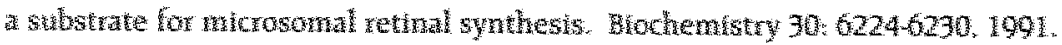

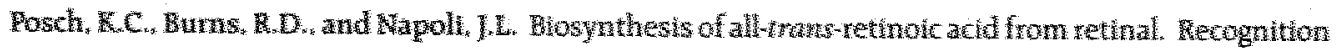

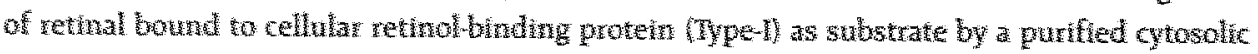

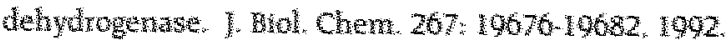


Puglisi, C.V., and DeSilva. J.A.F. Determination of retinoic act (13-cis-and all-hems-) and aromatic retinoic acid analogs possessing antitumor activity, in biological huds by high-performance hquid chromatography. J. Chromatogr. 152: 421-430, 1978.

Raner, G.M. Vaz A.D.N., and Coon, M.J. Metabolism of all-trans- 9-cis-and 13-cis-isomers of retinal by purified isozymes of microsomal cytochrome $\mathrm{P} 450$ and mechanism-based inhibition of retnoid oxidation by citral. Mol. Pharmacol. 49:515-522, 1996.

Repa, J.I. Hanson, K.K. and Clagett-Dame, M. All-trans-retinol is a ligand for the retinoic actd receptors. Proc Natl Acad. Sci. U.S.A 90: 7293-7297, 1993.

Rigas, J.R., Francis, P.A., Muindi, J.F., Kris, M.G., Huselton, C., DeGrazia, F, Orazem, J.P., Young, C.W., and Warrell. R.P.Jr. Constitutive variability in the phammacokinetics of the natural retinotd, alltrans-retinolc acid, and its modulation by ketoconazole. J. Natl. Cancer Inst 85:1921-1926. 1993.

Roberts, A.B., Nichols, M.D. Newton, D.L., and Sporn, M.B. In vitro metabolism of retinoic acid in hamster intestine and liver. J. Biol Chem. 254:6296-6302, 1979 a.

Roberts, A.B., Frolik, C.A., Nichols, M.D., and Sporn. M.B. Retinoid-dependent induction of the in vivo and in vitro metabolism of retinoic acid in tissues of the vitamin Adeficient hamster. J. Biol. Chem.. 254: 6303-6309. 19796.

Roberts, A.B., Lamb, L.C., and Sporn, M.B. Metabolism of all-trans-retinoic acid in hamster liver microsomes oxidation of 4-hydroxy- to 4-keto-retinoic acid. Arch. Biochem. Biophys. 199: 374383. 1980 .

Roberts, E.S., Vaz, A.D.N., and Coon, M.J. Role of isozymes of rabbit microsomal cytochrome P450 in the metabolism of retinoic acid, retinol, and retinal. Mol Pharmacol. 41: 427-433, 1992.

Rogers, M.B.. Watkins, S.C., and Gudas, L.J. Gene expression in visceral endoderm: a comparison of mutant and wild-type F9 embryonal carcinoma cell differentiation. J. Cell. Biol. 110: 1767-1777. 1990.

Sani, B.P. Barua, A.B., Hill, D.L. Shih. T.-W. and Olson. J.A. Retinoyl-B-gluctironides: Lack of binding to receptor proteins of retinoic acid as related to biological activity. Brochem. Pharmacol 43: 919-922, 1992.

Sass, J.O. Tzimas, G., and Nau, H. 9-cis-retinoyl-B-D-glucuronide is a major metabolite of 9-ci.5-retinolc acid. Life Sc1. 54: PL69-74. 1994.

Sass. J.O., Masgrau, E., Saurat, J.-H., and Nau, H. Metabolism of oral 9-cis-retinoic acid in the human. Identification of 9-cis-retinoyl-B-glucuronide and 9-cis-4-oxo-retinoyl-B-glucuronide as urinary metabolites. Drug Metab. Dispos. 23: 887-891, 1995.

Scott, R.E. Differentiation, differentiation/gene therapy and cancer. Pharmacol. Ther., 73: 51-65. 1997. 
Setdmon, E. ., Trump. D.L., Kreis, W. Hall, S.W., Kurman, M.R., Ouyang, S.P., Wu, J. and Kremer. A.B. Phase I/I dose-escalation study of larozole in pattents with stage $D$. hormone-refractory carcinoma of the prostate. Annu, Surg. Oncol. 2: 550-556, 1995.

ShH, T.W. Shealy, T.F., Strother, D.L. and Hill, D.L. Nonenzymatic isomerization of all-trans-and 13.cis-retinoids catalyzed by sulfhydryl groups. Drug Metab. Dispos. 14:698-702. 1986.

Shih, T.W., Lin, T,-H., Shealy, F, and Hill, D.L. Nonenzymatic isomerization of 9 cis-retinoic acid catalyzed by sulfhydryl compounds. Drug Metab. Dispos. 25: 27.32, 1997.

Skare, K.L., Schnoes, H.K, and DeLuca, H.F. Biliary metabolites of all-trans-retinoic acid in the rat: Isolation and identification of a novel polar metabolite. Biochemistry 21: 3308-3317.1982.

Smets, G. Van Ginckel, R. Daneels, G., Moeremans, M., Van Wauwe. J., Coene, M.-C., Ramaekers, F.C.S., Schalken, J.A., Borgers, $M_{\text {." }}$ and De Coster, $R$. Liarozole, an antitumor drug, modulates cytokeratin expression in the Dunning AT-6sq prostatic carcinoma through in situ accumulation of all-trans-retinoic acid. Prostate 27: 129-140. 1995.

Smith. J.E., Milch, P.O., Muto, Y., and Goodman, D.S. The plasma transport and metabolism of retinoik acid in the rat. Biochem. J. 132: 821-827, 1973.

Smith, M.A. Adamson, P.C. Balis, F.M., Feusner. J., Aronson, L.. Murphy, R.F., Horowitz, M.E., Reaman G. Hammond, G.D., Fenton, R.M., Connaghan "G.D." Hittelman, W.N., and Poplack, D.G. Phask I and pharmacokinetic evaluation of all-trans-retinoic acid in pediatric patients with cancer. I Clin. Oncol. 10: 1666-1673, 1992.

Soprano, D.R., and Blaner. W.S. Plasma retinol-binding protein. In: Spom, M.B., Roberts, A.B., Goodman D.S. (eds.). The Retinoids. Biology. Chemistry and Medicine, Ed. 2. pp 257-281. New York Raven Press, Ltd., 1994.

Stearns. M.E.. Wang. M., and Fudge, K. Liarozole and 13-cis-retinoic acid anti-prostatic tumor activity Cancer Res. 53: 3073-3077, 1993.

Strickland, $\mathrm{S}_{\text {., and Mahdavi }} \mathrm{V}$. The induction of differentiation in teratocarcinoma cells by retinoi acid Cell 15: 393-403, 1978 .

Strickland. S., and Sawey. M.J. Studies on the effect of retinoids on the differentiation o teratocarcinoma cells in witro and in viwo. Dev. Biol. 78: 76-85. 1980.

Strickland, S., Smith, K.K., and Marotti. K.R. Hormonal induction of differentiation in teratocarcinom stem cells: generation of parietal endoderm by retinoic acid and dibutyryl cAMP. Cell 21: 34; 355,1980 .

Strickland, S., Breitman, T.R., Frickel, F., Nurrenbach, A., Hadicke, E., and Sporn, M.B. Structurk activity relationships of a new series of retinoidal benzoic acid derivatives as measured $b$ Induction of differentiation of murine Fy teratocarcinoma cells and human HL-60 promyelocyti leukemia cells. Cancer Res. 43: 5368-5372, 1983. 
Takase, S, Ong, D.E., and Chytil, F. Transfer of retinoic acid from tts complex with cellular retinoic acid-binding protein to the nucleus. Arch. Biochem Biophys. $247,328-334,1986$.

Takitani, K. Tamaĭ, H., Morinobu. T., Kawamura, N., Miyake, M., Fujimoto, T., and Mino, M. Pharmacokinetics of all-trans-retinoic acid in pediatric patients with leukemia. Jpn. J. Cancer Res. 86: 400-405, 1995.

Tang, G., and Russell, R.M. 13-cis-Retinoic acid is an endogenous compound in human serum. J. Lipid Res. 30: 175-182, 1990.

Tang, G. and Russell R.M. Formation of all-trans-retinoic acid and 13-cis-retinoic acid from all-transretinyl palmitate in humans. J. Nutr. Biochem. 2: 210-213. 199\%.

Thaller, $\mathrm{C}$, and Eichele, G. Isolation of 3.4-didehydroretinoic acid, a novel morphogenetic signal in the chick wing bud. Nature (London) 345; 815-819. 1990.

Tzimas, G., Sass, J.O., Wittfoht. W. Elmazar, M.M.A., Ehlers, K, and Nau, H. Identification of 9.13dicis-retinoic acid as a major plasma metabolite of 9-cis-retinotc acid and limited transfer of 9 cis-retinoic acid and 9.13-dicis-retinoic acid to the mouse and rat embryos. Drug Metab. Dispos. 22: 928-936, 1994a.

Tzimas, G., Sass, J.O., Rühl, R., Klug, S., Collins, M.D.. and Nau, H. Proximate retinoid teratogens. In: Livrea, M.A., Vivaldi, G. (eds.). From basic science to dinical applications, pp. 179-195. Basel: Birkhäuser Verlag. 19946 .

Urbach. J., and Rando, R.R. Isomerization of all-trans-retinoic acid to 9-cis-retinoic acid. Blochem. J. 299: 459-465, 1994.

Van Ginckel, R., De Coster, R., Wouters, W. Vanherck, W., van der Veer, R., Goeminne, N., Jagers, E., Van Cauteren, H., Wouters, L., Distelmans, W., and Janssen, P.A.J. Antitumaral effects of R75251 on the growth of transplantable $\mathrm{R} 3327$ prostatic adenocarcinoma in rats. Prostate $16: 313323$, 1990.

Van Wauwe, J.P., Coene, M.-C., Goossens, J., Cools, W., and Monbalit, J. Effects of cytochrome P450 inhibitors on the in vivo metabolism of all-trans-retinoic acid in rats. J. Pharmacol. Exp. Ther. 252: 365-369, 1990.

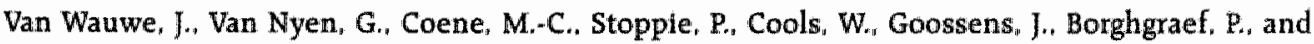
Janssen, P.A.J. Liarozole, an inhibitor of retinoic acid metabolism, exerts retinoid-mimetic effects in wivo. J. Pharmacol. Exp. Ther, 261: 773-779, 1992.

Vane, F.M., Buggé. C.].L., and Williams. T.H. Metabolism of 13-cis-retinoic acid by a rat liver $9000 \mathrm{~g}$. supernatant preparation. Drug Metab. Dispos. 10: 212-219, 1982.

Wang, X.D., Krinsky, N.I., Tang, G., and Russell, R.M. Retinotc acid can be produced from eccentric cleavage of B-carotene in human intestinal mucosa. Arch. Biochem. Biophys. 293: 298-304, 1992. 
Warrell, R.P. Frankel, S.R., Miller, W.H. Scheingexg, D.A. Itri, LM., Hittelman, W.N., Vyas, R, Andreef M. Tafuri, A., Jakubowski, A., Gabrilove, I., Gordon, M.S., and Dmitrovsky, E. Differentiatio therapy of acute promyelocytic leukemia with tretinoin (all-trans-retinoic acid). N. Eng. I. Mec 20: $1385-1393.1991$.

Warrell, R.P.Jr. de Thé, H. Wang, Z.Y., and Degos, L. Acute promyelocytic leukemia. N. Eng. J. Mex 329: 177-189, 1993.

Westarp, M.E., Westarp, M.P., Bruynseels, J., Bollag, W. and Kornhuber, H. - H. Oral liarozole as catabolic inhibitor potently increases retinoic acid in vivo: first experience from an ongoir. therapeutic trial in highly malignant primary brain tumors. Onkologie 16: 22-25. 1993.

White, J.A., Guo Y-D.. Baetz, K. Jones, B." Dilworth, F.J. Jones, G., and Petkovich, M. Identification ، the retinoic acid-inducible all-trans-retinoic acid 4-hydroxylase. J. Biol. Chem. 271: 29922-2992 1996.

Williams, J,B, and Napoli. J,L. Metabolism of retinoic acid and retinol during differentiation of I embryonal carcinoma cells. Proc. Natl. Acad. Sci. U.S.A. 82: 4658-4662, 1985.

Williams, J.B., and Napoli. J.L. Inhibition of retinoic acid metabolism by imidazole antimycotics in I embryonal carcinoma cells. Biochem. Pharmacol. 36: 1386-1388, 1987.

Wouters, W., van Dun. J., Dillen, A. Coene, M.-C., Cools, W., and De Coster, R. Effects of liarozole. new antitumor compound, on retinoic acid-induced inhibition of cell growth and on retino acid metabolism in MCF-7 human breast cancer cells. Cancer Res. 52: 2841-2846, 1992.

Wouters, W. Retinoid metabolism and its inhibition by liarozole-fumarate. Ann. Oncol. 5: S45-S4 1994.

Zhang, X.-K., Lehmann, J., Hoffmann, B., Dawson, M.I., Cameron. J.. Graupner, G., Hermann, T., Tra $P . x$ and Pfahl, M. Homodimer formation of retinoid $X$ receptor induced by 9-cis-retinoic aci Nature (London) 358: 587-591, 1992.

Zile, M.H., Cullum, M.E., Simpson, R.U., Barua, A.B., and Swartz, D.A. Induction of differentiation human promyelocytic leukemia cell line HL-60 by retinoyl glucuronide, a biologically acti metabolite of vitamin A. Proc. Natl. Acad. Sci. U.S.A. 84: 2208-2219. 1987. 


\section{Liarozole potentiates the all-trans-retinoic acid-induced structural remodelling in human breast carcinoma MCF-7 cells in vitro}

Eur. J. Cell Biol. 71: 89-98, 1996.

Jimmy Van heusden ${ }^{1}$, Marcel Borgers ${ }^{1.3}$. Frans C.S. Ramaekers ${ }^{1}$, Benoit Xhonneux ${ }^{2}$, Walter Wouters ${ }^{2}$, Roland De Coster ${ }^{4}$ and Gerda Smets ${ }^{2}$

'Department of Molecular Cell Biology \& Genetics, University of Maastricht, PO. Box 616,6200 MD Maastricht, The Netherlands: ${ }^{2}$ Departments of Oncology. ${ }^{3}$ Morphology and ${ }^{4}$ Safety Pharmacology, Janssen Research Foundation. Turnhoutseweg 30. B-2340 Beerse. Belgium

\section{Abstract}

Liarozole inhibits cytochrome $\mathrm{P} 450$-dependent enzymes that play a key role in all-trans-retinoic acid (ATRA) catabolism. In MCF-7 cells, liarozole potentiates the antiproliferative effects of ATRA. The present study demonstrates this synergistic effect on cell differentiation of MCF-7 cell cultures as measured by immunocytochemistry for cytokeratins 8,18 , and 19. actin. E-cadherin, desmoglein and desmoplakins I \& Il. ATRA concentration-dependently $\left(10^{-8} \mathrm{M}\right.$ to $\left.10^{-6} \mathrm{M}\right)$ induced changes in actin stress 
fibers and cytokeratin intermediate filaments. These changes wer accompanied by a more obvious interaction of these filaments with junctiona complexes. Surface area and volume of the MCF-7 cells increased markedl after ATRA exposure, with extensive filopodia formation. Liarozol $\left(10^{-6} \mathrm{M}\right)$ alone had no effect on cell morphology, cytokeratin or acti: organization, or on cellular junctions. In combination with ATRA $\left(10^{-9} \mathrm{~A}\right.$ and $10^{-8} \mathrm{M}$ ), liarozole potentiated the ATRA-induced effects. The MCF-7 ce] cultures used showed morphological heterogeneity, consisting of at leas two cellular subpopulations. This was reflected in the staining for E-cadherir desmoglein and desmoplakins I \& II. ATRA increased E-cadherin staining a cell-cell contact sites, but had no influence on the staining patterns o desmoglein and desmoplakins I \& II. Similar to what has been observed fo the cytoskeletal differentiation parameters, liarozole alone had no influenc on E-cadherin, desmoglein or desmoplakins I \& II expression, but is combination with ATRA again intensified the effects on E-cadheriy distribution. These effects on MCF-7 cells agree with previously obtaine observations concerning the inhibition of ATRA catabolism by liarozole Furthermore, our data support the hypothesis that the antiproliferativ properties of the drug are accompanied by induction of differentiation.

\section{Introduction}

Liarozole is currently in phase III clinical trials for the treatment of relapsed prostate cal Liarozole exerts retinoid-mimetic effects in both animals and patients (Van Wauwe $e_{1}$ 1992: Mahler et al., 1993). Recently it has been shown that liarozole acts as a vers inhibitor of cytochrome P450-dependent all-trans-retinoic acid (ATRA) catabolism, inhib both the 4-hydroxylation of ATRA and the monohydroxylation reactions of 4-oxo-ATRA Wauwe et al. 1990, 1994). The drug reduces tumor growth of androgen-dependent androgen-independent Dunning R3327 rat prostate adenocarcinoma cells (Van Ginck al. 1990: De Coster et al. 1992; Dijkman et al. 1994: Smets et al. 1995) and of the andro independent PC-3ML-B2 human prostate carcinoma xenografts (Stearns et al., 1993). T: together these biochemical and clinical results have given rise to the hypothesis that liarc may exert its antitumoral effects by inhibition of the cytochrome P450-dependent $A$ catabolism. 
In MCF-7 human breast carcinoma cell cultures. liarozole has been shown to enhance the antiproliferative effects of ATRA (Wouters et al., 1992). This enhancement was dependent on the concentration of liarozole (between $10^{-7} \mathrm{M}$ and $10^{-5} \mathrm{M}$ ) and was more than 10-fold. Under basal growth conditions, MCF-7 cells are unable to metabolize ATRA, as shown by high-performance liquid chromatography. However. pretreatment with ATRA induced a very active conversion of ATRA to more polar metabolites. This conversion was almost completely inhibited by liarozole at a concentration of $10^{-5} \mathrm{M}$ (Wouters et al., 1992). Also in F9 mouse teratocarcinoma cells, liarozole enhanced the effect of ATRA on the induction of plasminogen activator more than 2-fold (De Coster et al., 1992). In both cell lines, liarozole alone, showed no intrinsic retinoid activity and did not inhibit proliferation (De Coster et al., 1992: Wouters et al. 1992).

It is now well established that ATRA exerts antiproliferative and differentiation-inducing effects on malignant cells (Lotan. 1980). These effects are believed to be directly exerted at the level of gene expression by nuclear retinoic acid receptors and retinoid $X$ receptors that are structurally and functionally related to the steroid/thyroid hormone receptor superfamily (Giguère, 1994; Mangelsdorf et al., 1994). In this respect, retinoic acid has repeatedly been shown to be an important regulator of epithelial differentiation (Chytil, 1984: Wolf. 1984). Such processes are often characterized by the reorganization of the cytoskeleton (Lehtonen et al., 1983; Ng et al.. 1985: Rutka et al.. 1988; Helige et al., 1993; Plateroti et al., 1993). These filamentous structures associate with a diversity of adhesion molecules at cell-cell contact sites. For example, the cytokeratin intermediate filaments are anchored to desmosomes, containing desmoplakin and desmoglein (Schmidt et al., 1994), and actin microfilaments are linked to adherence type junctions " comprising cadherins (Takeichi. 1991). This interaction of the cytoskeleton with adhesion molecules in the cellular membrane is crucial for maintenance of the proper integrity of tissues (Fleming. 1991: Gumbiner, 1993). The present study explores the current hypothesis according to which liarozole exerts its antitumoral effects by inhibiting ATRA catabolism. MCF-7 human breast cancer cells have an inducible ATRA metabolism and were used to confirm the potentiation of the antiproliferative ATRA effect by liarozole, under the same culture conditions as previously described (Wouters et al., 1992). Furthermore, the differentiation-inducing effects of ATRA on MCF-7 cells were investigated, and tests were carried out to determine whether liarozole was able to potentiate these effects. To monitor the process of differentiation, cytoskeletal proteins (cytokeratins and actin) and cellular junctions (E-cadherin, desmoglein and desmoplakins I \& II) were visualized by immunocytochemistry. 


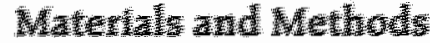

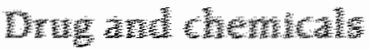

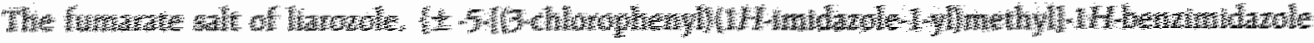

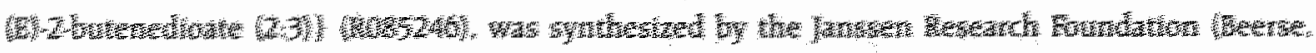

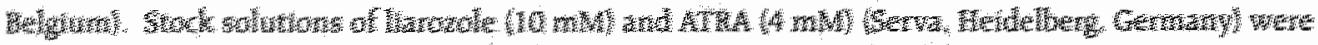

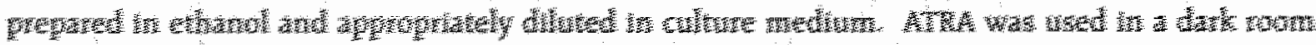

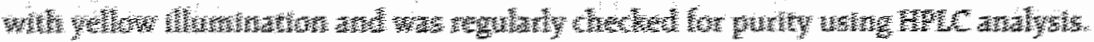

\section{collowinge}

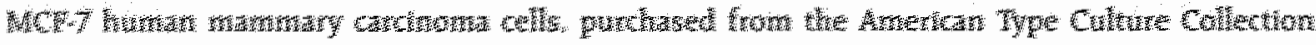

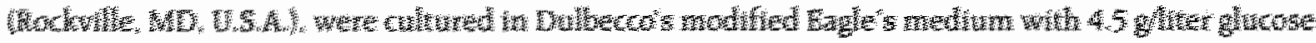

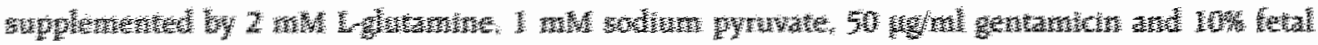

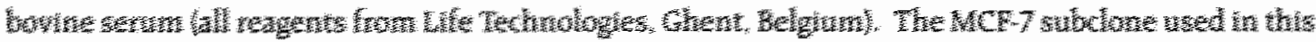

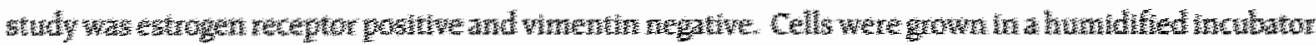

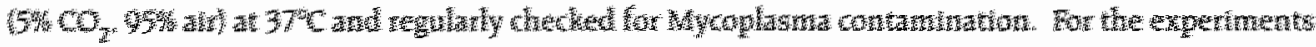

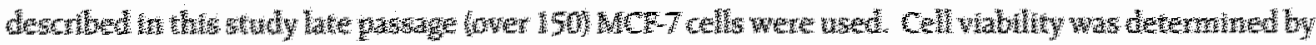
17y

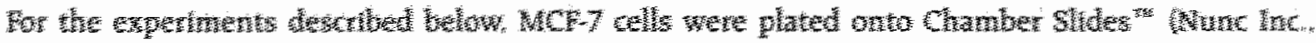

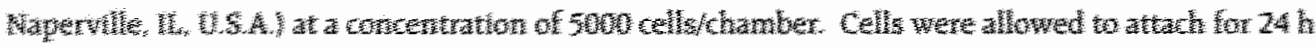

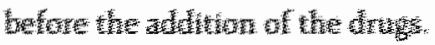

\section{Drug racubations}

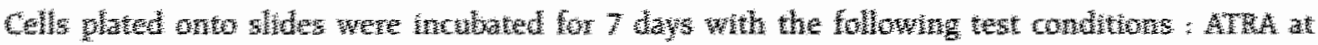

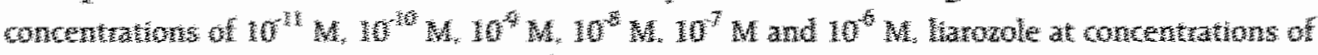
$10^{-7} \mathrm{M} \cdot 10^{-6} \mathrm{M}$ and $10^{-5} \mathrm{M}$ and liarozole $\left(10^{* 5} \mathrm{M}\right)$ in combination with ATRA at concentrations of $10^{*} \mathrm{M}$. $10^{-6} \mathrm{M}$ and $10^{-8} \mathrm{M}$. Medium was changed on days 2 and 5. Under control conditions, cells reached. confluence after 7 days.

\section{Scanning electron microscopy (S.E.M.)}

Cells grown with or without test compounds for 7 days were washed twice for $15 \mathrm{~min}$ in serum-free culture medium. Cells were fixed in $2 \%$ paraformaldehyde (Merck. Darmstadt. Germany) and 2.5\% glutaraldehyde (Fluka, Buchs, Switzerland) buffered in $0.1 \mathrm{M}$ phosphate buffer ( $\mathrm{pH} 7.4$ ) for $24 \mathrm{~h}$. After being washed in $7.5 \%$ sucrose (Merck) in $0.1 \mathrm{M}$ phosphate buffer ( $\mathrm{pH} 7.4$ ). cells were postfixed for $1 \mathrm{~h}$ at $4 \%$ in $2 \%$ osmium tetroxide (Acros Chimica, Geel, Belgium) in $0.05 \mathrm{M}$ veronal acetate (pH 7.4). The slides were washed twice for $5 \mathrm{~min}$ in $7 \%$ sucrose in $0.05 \mathrm{M}$ veronal acetate and dehydrated through a graded series of ethanol and acetone. The samples were mounted and shadowed with $30 \mathrm{~nm}$ gold. They were examined and photographed in a Philips XL20 scanning electron microscope. 


\section{Transmission electron microscopy}

Cells grown with or without test compounds for 7 days were fixed and postfixed as described for scanning electron microscopy. Thereafter, they were stained with $0.5 \%$ uranyl acetate (Mercly) in 0.05 $M$ veronal acetate ( $\mathrm{pH} 5.2$ ) for $40 \mathrm{~min}$ at room temperature. After the cells were washed twice for 5 min with $0.05 \mathrm{M}$ weronal acetate (pH 5.2). they were dehydrated by ethanol and embedded in Epon. Sections $110 \mathrm{~nm}$ thick were cut with a diamond knife and collected on Formwar-coated grids (300 mesh). They were examined and photographed in a Philips EM410 electron microscope.

\section{Bromodeoxyuridine (BrdU) incorporation and immunodetection}

Cells grown with or without test compounds for 7 days were incubated for $2.5 \mathrm{~h}$ with an excess $\$ 100$ $\mu \mathrm{M}$ ) of 5-bromo-2"-deoxyuridine (Brdu) (Acros Chimica) in serum-free culture medium. Then cells were washed three times for $15 \mathrm{~min}$ with a mixture of culture medium and $0.1 \mathrm{M}$ phosphate buffer $(\mathrm{pH} 7.4)(8: 2 \mathrm{v} / \mathrm{v})$. Cells were subsequently fixed in methanol $\left(5 \mathrm{~min},-20^{\circ} \mathrm{C}\right)$, acetone $\left(10 \mathrm{~s},-20^{\circ} \mathrm{C}\right)$ and air-dried. Denaturation of the DNA was performed with $1 \%$ periodic acid (Merck) for $30 \mathrm{~min}$ at $60^{\circ} \mathrm{C}$. followed by Schiff"s reagent (Sigma Diagnostics, St. Louis, MO, U.S.A.) for $30 \mathrm{~min}$ at room temperature. Cells were washed three times with distilled water and treated with $0.01 \%$ trypsin (Life Technologies. Ghent, Belgium) in $0.05 \mathrm{M}$ Tris-HCl (pH 7.6). After the cells were washed in $0.05 \mathrm{M} \mathrm{Tris-HCl}$ (pH 7.6) and $0.1 \mathrm{M}$ phosphate buffer, the slides were subsequently blocked in $0.5 \%$ lysozyme in $0.1 \mathrm{M}$ phosphate buffer for $1 \mathrm{~h}$, incubated overnight at room temperature in a moist chamber with a primary monoclonal antibody against BrdU (1:50) (Janssen Biochimica. Beerse, Belgium) and antibody binding visualized with a secondary gold-labeled (5 nm) goat anti-mouse IgG (1:50) (Amersham Internationall, Little Chalfont. Buckinghamshire, United Kingdom). The signal was enhanced for light microscopy with a sillver enhancement kit (Amersham International).

The BrdU labeling index was defined as the proportion of BrdU positive cells, representing cells in Sphase. It was calculated by counting 700 cells per incubation per test condition (see drug conditions). Average results of six experiments are presented.

\section{Immunocy tochemistry}

Cells grown with or without test compounds for 7 days were washed twice with serum-free culture medium. Cells were fixed in methanol $\left(5 \mathrm{~min},-20^{\circ} \mathrm{C}\right)$ and acetone $\left(10 \mathrm{~s},-20^{\circ} \mathrm{C}\right)$ and alrudried. Cells were subsequently blocked in $5 \%$ normal goat serum in $10 \mathrm{mM}$ phosphate buffered saline (PBS) (pH 7.4) for $1 \mathrm{~h}$, incubated for $\mathrm{l}$ h at room temperature in a dark moist chamber with the primary monoclonal antibody and visualized with the immunofluorescence technique using a secondary fluorescein isothiocyanate (FITC)-labeled goat anti-mouse lgG (Southern Biotechnology Associates, Birmingham, AL. U.S.A.). Slides were air-dried and mounted in Mowiol (Hoechst. Frankfurt a.M., Germany). Nuclel were stained with 4-6-diamidine 2-0-phenylindole (DAPI; diluted 1:40000) (Sigma Chemicalls). The characteristics and references of the primary antibodies used in this study are summarized in Table I. 
Table ll: Primary monoclonal antibodies used for immunocytochemistry

\begin{tabular}{|c|c|c|c|c|c|}
\hline Antbody & Hg subclass: & Dilution & Antigen recognized & Source & Reference \\
\hline$\overline{\mathrm{AC}-15}$ & $\operatorname{Ig} G_{\sharp}$ & $1: 1000$ & Bactin & Sigma & North et al, 1994 \\
\hline DG 3.10 & $\lg G_{\sharp}$ & $1: 10$ & desmaglein & Progen & Schmels et al., 1980 \\
\hline $\mathrm{DP} 1: 2$ & $\lg G_{\|}$ & $1: 10$ & desmoplakins 1 II & Progen & Franke al al, 1983 \\
\hline HECD-1 & $\operatorname{lg~G}$ & $1: 400$ & E-cadherin & TakaRa & Shimoyama tal., 1989 \\
\hline LPZZK & $\operatorname{Ig} \mathrm{G}_{2 \mathrm{~b}}$ & $1: 10$ & cytokeratin 19 & F. Ramaekers & Broers et al. 1986 \\
\hline$M 20$ & $\lg G_{\Downarrow}$ & $1: 3$ & cytokeratin 8 & E. Ramaekers & Schaafsma et al, 1989 \\
\hline MCC.CAD-299 & $\lg \mathrm{G}_{\|}$ & $1: 200$ & P-cadherin & TakaRa & Shimoyama et al. 1989 \\
\hline RCK 106 & $\operatorname{Ig} G_{\|}$ & $1: 5$ & cytokeratin 18 & E. Ramaekers & Ramaekers et al. 1987 \\
\hline RV203 & $\lg \mathrm{G}_{\|}$ & $1: 5$ & vimentin & F. Ramaekers & Schaart et al. 1991 \\
\hline
\end{tabular}

\section{One- and two-dimensional gel electrophoresis}

Equal numbers of control and ATRA-treated cells $\left(4.5 \times 10^{6}\right)$ were washed with $10 \mathrm{mM} \mathrm{PBS}$ (pH 7.4) and scraped into sodium dodecyl sulfate (SDS)-electrophoresis sample buffer (Laemmli. 1970) and boiled for $10 \mathrm{~min}$. For one-dimensional gel electrophoresis, samples were diluted 1:4, and proteins were electrophoretically separated on 12\% SDS-containing polyacrylamide gels (Mini Protean II Cell: BioRad Laboratories, Nazareth. Belgium). Gels were stained with Coomassie Birilliant Blue R250.

For two-dimensional gell ellectrophoresis the samples were prepared as described above. Before loading onto isoelectric focusing (IEF) -gels, an equal volume of buffer containing $2 \%$ Nonidet P-40 (Fluka). 5\% B-mercaptoethanol (Merck). 5\% Bio-Lyte carrier ampholytes (pH 3-10) (Bio-Rad Laboratories) and $9 \mathrm{M}$ urea (Merck) was added followed by addition of 1 M 3-13-cholamidopropyl)-dimethylammoniol-1 propane sulfonate (CHAPS) (Sigma) $(1: 4 \mathrm{v} / \mathrm{v})$ and urea until saturation (Cupo et al., 1990). Twodimensional gell electrophoresis (Mini-Protean II 2-D system. Bio-Rad Laboratories) was performed as described by O'Farrell (1975) "with the following modifications.

In the first dimension, IEF was performed in $4 \%$ polyacrylamide rod gels containing $8 \mathrm{M}$ urea, $1.3 \%$ Bio-Lyte carrier ampholytes (pH 3-10) and $12.5 \mathrm{mM}$ CHAPS. For IEF no preelectrophoresis was performed. Gels were run at increasing voltages starting at $500 \mathrm{~V}$ for $10 \mathrm{~min}$, followed by $1000 \mathrm{~V}$ for $20 \mathrm{~min}$ and $1500 \mathrm{~V}$ for $100 \mathrm{~min}$. For the second dimension, the rod gels were applied directly onto the stacking gel of a 10\% SDS-containing polyacrylamide gel. The gels were stained with Coomassie Brilliant Blue R250. The stained protein bands were quantitated by digitizing with a RX5 wideocamera attached to a Macintosh $\mathrm{II}_{\mathrm{FX}}$ computer. Integration of the optical density was performed with the Image 1.44 software (NIH. Bethesda. MD. U.S.A.). Signals were corrected for background.

\section{Statistical analysis}

Where appropriate, data were analyzed using the two-tailed Mann-Whitney $U$-test using the Stat View II software (Abacus Concepts. Inc. Berkeley, CA, U.S.A.). Significance was defined at the level of " $p<$ 0.05 . 


\section{Results}

Liarozole enhances ATRA effects on MCF-7 cell morphology

MCF-7 cell monolayers showed morphological heterogeneity. As illustrated in the scanning electron micrographs, about 80 to $90 \%$ of the cells in MCF-7 cultures exhibited a small, round and tightly packed morphology (Fig. 1a). occasionally forming glandular structures (Fig. 1c). About 10 to $20 \%$ of the cell population consisted of large cells (Fig. 1b), mostly single growing. They were obviously more voluminous, exhibited a lower ratio of nuclear to cytoplasmic area and formed sparse loose intercellular junctions.

Increasing ATRA concentrations were tested for their influence on cell morphology. Both cell populations had an increased surface area and became clearly more voluminous at ATRA concentrations of $10^{-8} \mathrm{M}$ to $10^{-6} \mathrm{M}$ (Fig. 1d), with the induction of membrane ruffling.
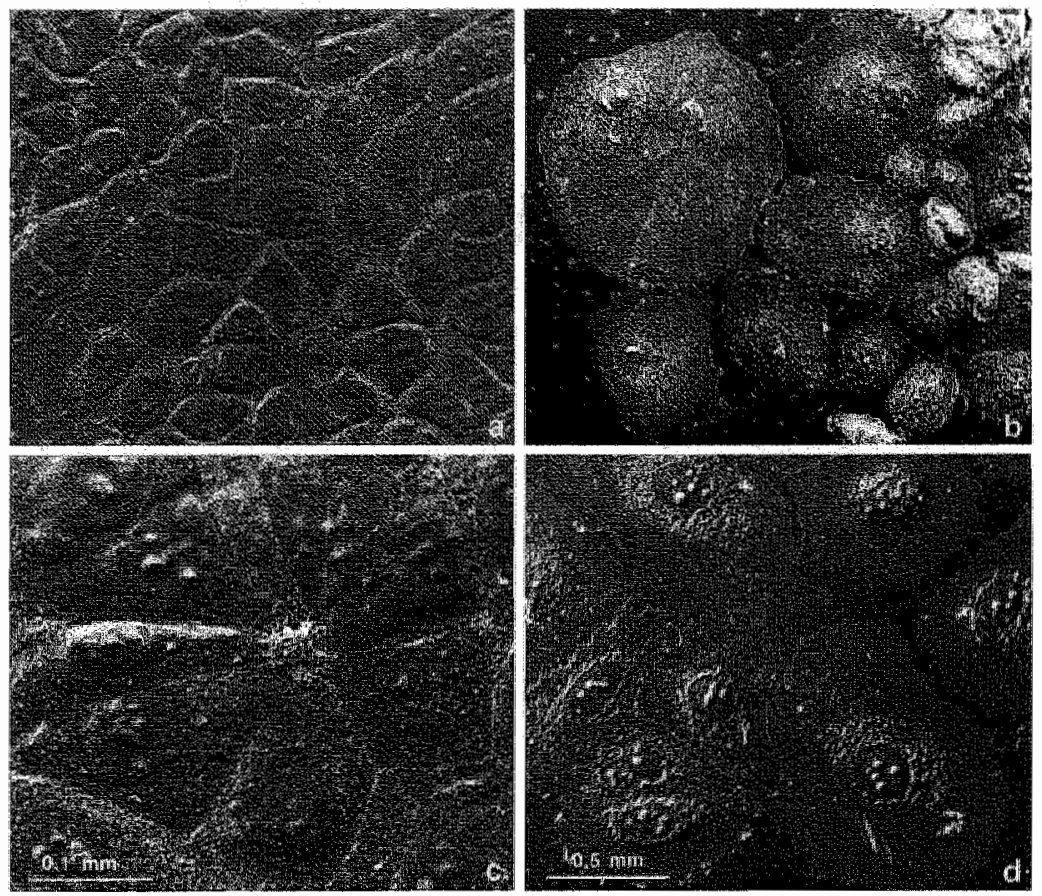

Figure I: Effect of $10^{-6} \mathrm{M}$ ATRA on the heterogeneous MCF-7 cell population, analyzed by S.E.M. A majority of small cells (a) and a minority of large cells (b) is observed under control conditions. Occasionally, glandular structures (c) could be detected. $10^{-6} \mathrm{M}$ ATRA increased the size of both cell populations (d). It induced membrane ruffling in the small cells and the formation of filopodia in the large cells. - Bars $0.5 \mathrm{~mm}(\mathrm{a}, \mathrm{b}, \mathrm{d}), 0.1 \mathrm{~mm}(\mathrm{c})$. 
especially in the population of small cells, and the formation of extensive filopodia, especially in the large cells. Furthermore, all cells appeared to have lower ratios of nuclear to cytoplasmic area. At $10^{-6} \mathrm{M}$ ATRA, virtually no small cells were noted. The morphological distinction between small and large cells diminished to a large extent, but was still evaluable by scoring membrane ruffling and filopodia, respectively. Below $10^{-7} \mathrm{M}$ ATRA again small cells were observed as under control conditions. Liarozole alone at $10^{6} \mathrm{M}$ did not induce morphological changes. However, simultaneous addition of $10^{.6} \mathrm{M}$ liarozole and $10^{-10} \mathrm{M}$ to $10^{-8} \mathrm{M}$ ATRA. resulted in a clear potentiation of the ATRA-induced effect (data not shown).

Synergistic effects of liarozole and ATRA on inhibition of MCF-7 cell proliferation

The concentration-dependent effects of ATRA and liarozole on proliferative activity of MCF-7 cells are shown in Figure 2. As presented in Figure 2a, the BrdU labeling index for the subpopulation of small cells under control conditions was $36.8 \pm 1.3 \%(n=6)$. The BrdU labeling index decreased only slightly when going from $10^{-11} \mathrm{M}$ to $10^{-7} \mathrm{M}$ ATRA. Liarozole alone up to a concentration of $10^{6} \mathrm{M}$ had no effect on the BrdU labeling index. At $10^{-5} \mathrm{M}$. liarozole lowered the $\mathrm{BrdU}$ labeling index to $27.8 \pm 0.5 \%(n=6)$. Simultaneous application of $10^{-6} \mathrm{M}$ liarozole and ATRA however, resulted in a significant 10-fold potentiation of the antiproliferative effect of ATRA. Although ATRA $\left(10^{-8} \mathrm{M}\right)$ alone had only a minor effect on the BrdU labeling index. ATRA in combination with liarozole $\left(10^{-6} \mathrm{M}\right)$ resulted in a 2-fold decrease of the number of cells in S-phase. At concentrations of $10^{-6} \mathrm{M}$ ATRA alone and $10^{-7} \mathrm{M}$ and $10^{6} \mathrm{M}$ ATRA in combination with $10^{-6} \mathrm{M}$ liarozole, the BrdU labeling index could not be evaluated because there were virtually no small cells noted.

The antiproliferative effects of ATRA could be established in both subpopulations of MCF-7 cells. As presented in Figure $2 b$, the Brdu labeling index for the large MCF-7 cells under control conditions was $42.2 \pm 0.8 \%(n=6)$. Cells responded in a concentration-dependent manner to increasing ATRA concentrations. The BrdU labeling index of the large MCF-7 cells decreased 2-fold when going from $10^{-11} \mathrm{M}$ to $10^{-7} \mathrm{M}$ ATRA. Under these conditions, the drug concentration necessary to attain $50 \%$ growth inhibition was $5.6 \times 10^{-8} \mathrm{M}$. Again, liarozole alone up to $10^{-6} \mathrm{M}$ had no effect. At $10^{-5} \mathrm{M}$. liarozole lowered the Brdu labeling index to $29.5 \pm 1.1 \%(n=6)$. In large cells too, liarozole at $10^{-6} \mathrm{M}$ significantly potentiated the antiproliferative effect of ATRA by 10-fold. Note that liarozole is unable to potentiate the effect of $10^{6} \mathrm{M}$ ATRA. 
Figure 2: Concentrationresponse curves showing the effects of ATRA and liarozole on BrdU incorporation in small (a) and large (b) MCF-7 cells. Cells were seeded at 5000 cells/well and treated with warious test compounds one day thereafter. On day 7 after plating, cells were labeled with BrdU. After immunadetection, cells were counted to obtain the BrdU labeling index. Results are presented as mean $\pm \operatorname{SEM}(n=6)$. (O) - ATRA; (a) - liarozole; $(\Delta)$ - ATRA + $10^{-6} \mathrm{M}$ liarozole. Significance: $p<0.05$ versus contral; $p<0.05$ versus ATRA treatment.
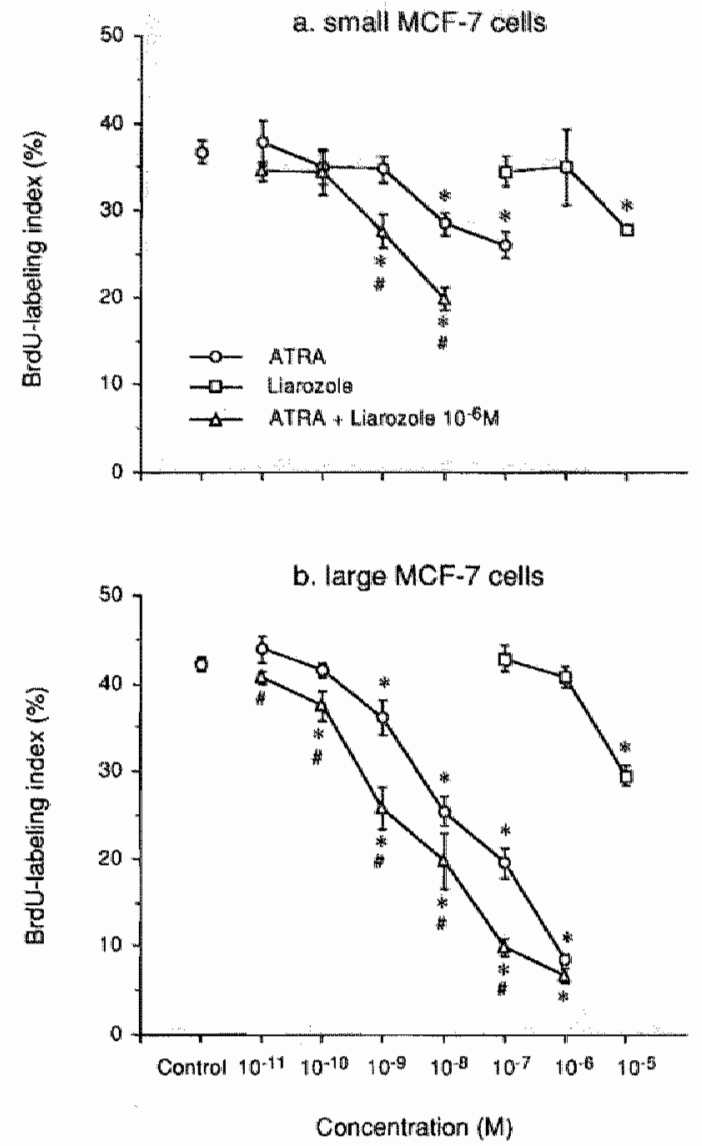

Liarozole potentiates the ATRA modulation of cell adhesion molecules in MCF-7 cells

The presence of desmosomes and adherens junctions in MCF-7 cells under control conditions is illustrated in the transmission electron micrographs in Figure 3. Intermediate filaments were associated with desmosomes (Fig. 3b). Typical adherens junctions were only present at the apical zone of neighboring cells (Fig. 3c). consistent with the polarization of the MCF-7 cells (Fig. 3a). 


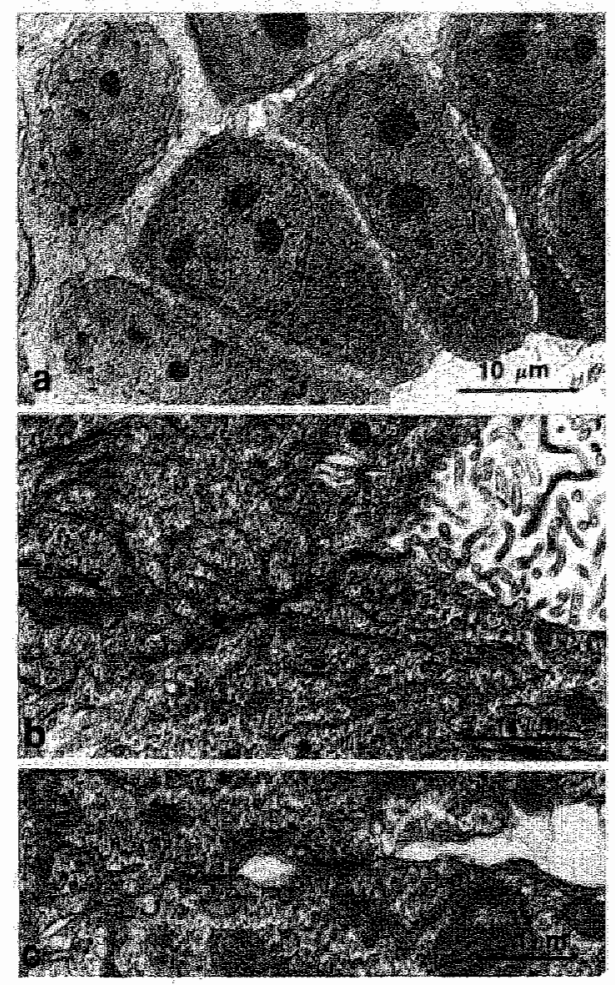

Figure 3: MCF-7 cells, as analyzed by transmission electron microscopy, showed a polarized organization (a) and were connected by a few welldeveloped cell-cell junctions. Intermediate filaments were associated with desmosomes (b). Adherens junctions were present at the apicall site of neighboring cells (c). - Bars $10 \mu \mathrm{m}$ (a), I $\mu \mathrm{m}$ (b, c).

The effect of ATRA on the expression of cell adhesion molecules was investigated. MCF-7 cells were negative for $\mathrm{P}$-cadherin under all conditions tested (data not shown). The staining results of E-cadherin showed a clear relationship with the morphological heterogeneity of the cell population. The subpopulation of small cells (Fig. 4a) showed a clear E-cadherin staining along the cell membranes, accompanied by some punctate cytoplasmic staining. In large cells (Fig. 4f) E-cadherin staining was predominantly faint, solely localized in the cytoplasm, while at the cell-cell contacts E-cadherin staining was completely negative. With $10^{-8} \mathrm{M}$ (Fig. 4c) to $10^{-6} \mathrm{M}$ ATRA (Fig. 4b), the ruffled membrane of the small cells showed an intense E-cadherin signal, indicative of an up-regulation of this constituent. Upon treatment with $10^{-8} \mathrm{M}$ (Fig. 4h) and $10^{-6} \mathrm{M}$ ATRA (Fig. $4 \mathrm{~g}$ ), the cell junctions at the filopodia of the large cells now showed E-cadherin staining. $10^{-6} \mathrm{M}$ liarozole alone (Figs. $4 \mathrm{~d}$, i) had no effect on $\mathrm{E}$ cadherin staining, but in combination with $10^{-4} \mathrm{M}$ and $10^{-8} \mathrm{M}$ (Figs. 4e, j) ATRA, the drug intensified the ATRA-induced changes at the level of the cell-cell contacts, as scored by an increased ruffling of the membrane, indicative for an up-regulation of E-cadherin. 
Similar to E-cadherin staining, staining for desmoplakins I II and desmoglein showed a clear relationship with the different cell types of the culture (data not shown). Under control conditions, the subpopulation of small cells presented a clear punctate staining along the cell membranes. The subpopulation of large cells was either completely negative or showed some dot-like staining at cell-cell contacts. The small cells retained a dot-like staining at $10^{-8} \mathrm{M}$ to $10^{-6} \mathrm{M}$ ATRA (data not shown). Similarly. after treatment with $10^{-8} \mathrm{M}$ to $10^{-6} \mathrm{M}$ ATRA, the large cells showed no difference in the adhesion molecule staining patterns as compared to control cells (data not shown). They remained either completely negative or showed a dot-like reactivity at cell-cell contacts. Liarozole alone or in combination with $10^{-9} \mathrm{M}$ and $10^{-8} \mathrm{M}$ ATRA had no effect on the staining pattems for desmoglein and desmoplakins I \& II (data not shown).
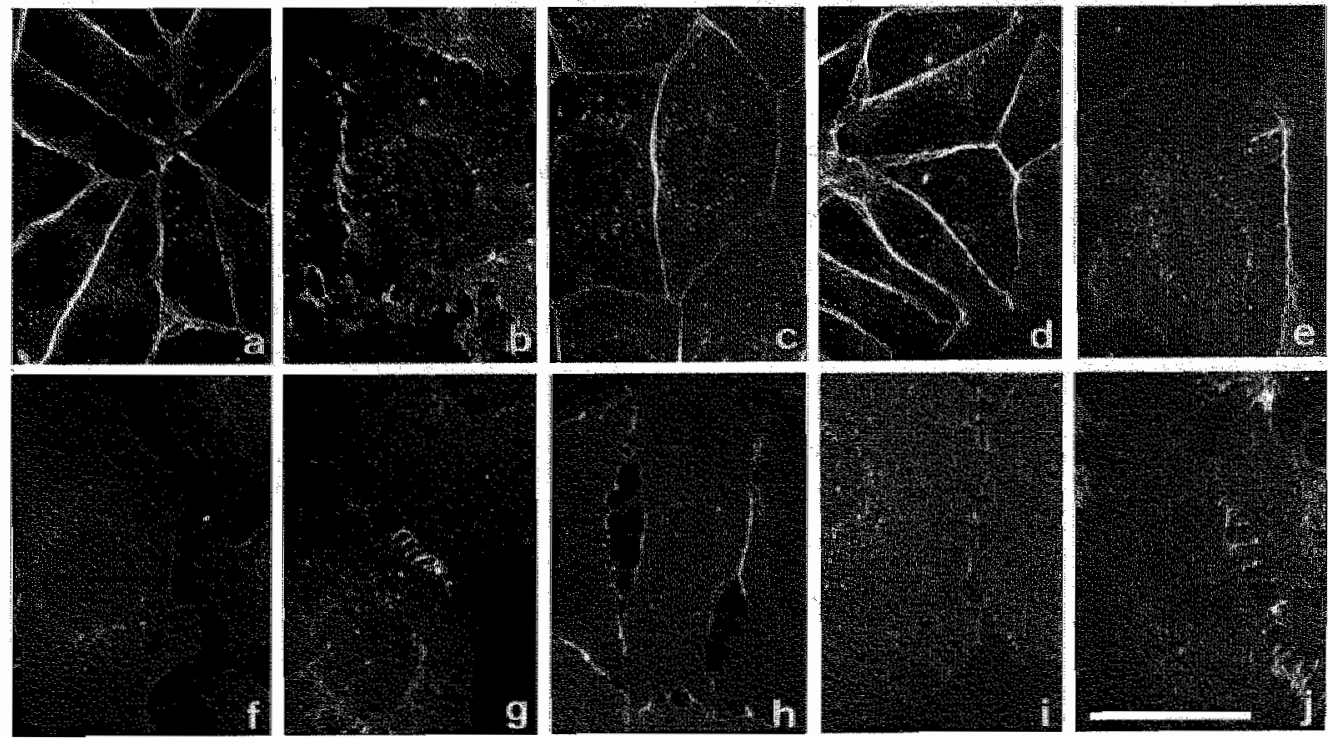

Figure 4: Effects of ATRA and liarozale on the distribution patterns of E-cadherin in small (ae) and large ( $f-j)$ MCF-7 cells. Conditions tested: control $(a, f), 10^{-6}$ MATRA $(b, g), 10^{-6} \mathrm{M}$ ATRA $(c, h), 10^{-6}$ M liarozole $(d, i), 10^{-6} \mathrm{M}$ liarozole in combination with $10^{-8}$ M ATRA (e, i). - Bar $0.1 \mathrm{~mm}$. 

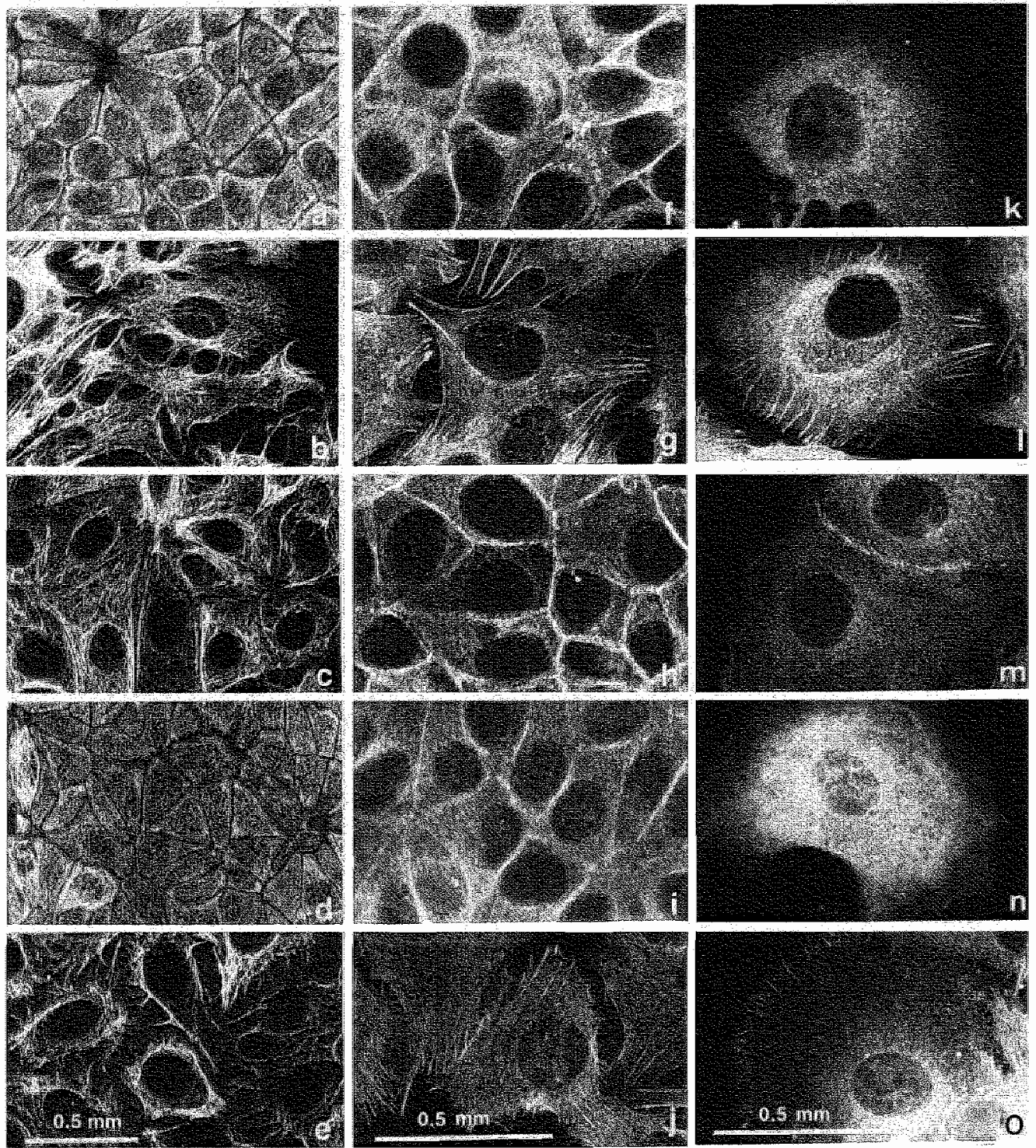

Figure 5: Effects of ATRA and liarozolle on the organization of the cytoskelleton, comprising cytokeratins ( $a-e)$ and actin ( $f-0)$ in small $(a-i)$ and large $(k-0)$ MCF-7 cells. Conditions tested: controll $(a, r, k), 10^{-6} \operatorname{MATRA}(b, g, l), 10^{-8} \operatorname{MATRA}(c, h, m), 10^{-6}$ M liarozole $(d, i, n), 10^{-6} M$ liarozole in combination with $10^{-8}$ M ATRA $(e, j, o)$. - Bars $0.5 \mathrm{~mm}(\mathrm{a}-\mathrm{e}), 0.5 \mathrm{~mm}(\mathrm{f}-\mathrm{o})$. 
Enhanced effects of ATRA in combination with liarozole on the cytoskeletal organization of $\mathrm{MCF}-7$ cells

In parallel with the changes in cell shape, a reorganization of cytoskeletal filaments was observed. The effect of ATRA (ranging from $10^{-11} \mathrm{M}-10^{-6} \mathrm{M}$ ) alone or in combination with liarozole $\left(10^{-6} \mathrm{M}\right)$ on the organization of the cytoskeleton was tested by immunocytochemical staining for cytokeratins $8,18,19$, actin and vimentin.

The MCF-7 cell clone used in this study was negative for vimentin under all conditions tested (data not shown). The results for the cytokeratin intermediate filaments are essentially the same for the different cytokeratin subtypes. Under control conditions, the staining pattern for cytokeratins in both MCF-7 cell subpopulations was characterized by a compact network of filaments (Fig. 5a). $10^{-7} \mathrm{M}$ and $10^{-6} \mathrm{M}$ (Fig. 5b) ATRA changed the organization to such an extent that a clear cytokeratin filamentous network running across the whole cell became visible. Also at a concentration of $10^{-8} \mathrm{M}$ ATRA (Fig. 5c), this effect was still visible. although less pronounced as compared to $10^{-6} \mathrm{M}$ ATRA. With $10^{-6} \mathrm{M}$ liarozole alone (Fig. $5 \mathrm{~d}$ ), the immunocytochemical staining results resembled those for control conditions. However, $10^{-6} \mathrm{M}$ liarozole in combination with $10^{-9} \mathrm{M}$ and $10^{-8} \mathrm{M}$ (Fig. 5e) ATRA potentiated the ATRA-induced effect, as illustrated by the presence of clear cytokeratin filaments and numerous cell-cell contact sites. At numerous foci of cell-cell adhesion points, cytokeratin filaments could be seen to interact with desmosomal junctions (Figs. 5b, e).

Gel electrophoretic analysis of the ATRA-treated cells showed a decrease in total cytokeratin content, as compared to the histone content (Fig. 6). Two-dimensional gel electrophoresis (Fig. 7) showed a clear decrease of all three cytokeratins 8.18 and 19 at $10^{-6}$ M ATRA, in relation to several other proteins which remained present at a constant level. Densitometrical analysis showed a decrease of cytokeratins 8,18 and 19 of approximately $50 \%$ after treatment with $10^{-6} \mathrm{M}$ ATRA.

Similar to the changes described for cytokeratins, ATRA treatment resulted in profound effects on the actin-containing stress fibers. Under control conditions, actin was seen as stress fibers along the cell membrane and as a more diffusely staining meshwork in the cytoplasm (Figs. 5f, k). Treatment with $10^{-7} \mathrm{M}$ and $10^{-6} \mathrm{M}$ (Figs. 5g. 1) ATRA induced numerous actin-containing stress fibers throughout the cell. In addition, numerous focal adhesions became apparent. After treatment with $10^{\circ} \mathrm{M}$ ATRA (Figs. $5 \mathrm{~h}, \mathrm{~m}$ ), actin staining predominantly resembled what was observed under control conditions. $10^{-6} \mathrm{M}$ liarozole alone induced no actin reorganization (Figs. 5i, n). but when the drug was given 


\section{Chapter 2}

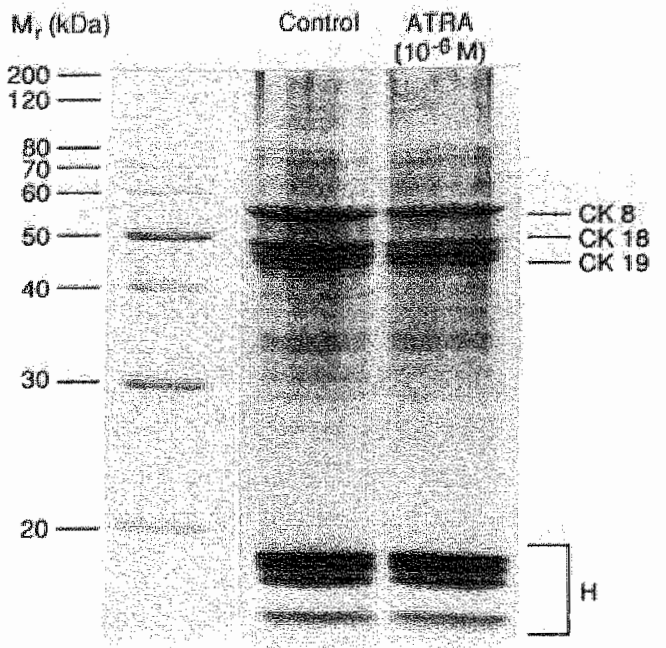

Figure 6: One-dimensional gel electrophoresis of total protein from equal numbers of control cells and cells treated with $10^{-6}$ M ATRA. - CK Cytokeratin. $H$ Histones.

simultaneously with $10^{-9} \mathrm{M}$ and $10^{-8} \mathrm{M}$ (Figs. 5j, o) ATRA, it clearly enhanced the formation of stress fibers and focal adhesions.

Two-dimensional gel electrophoresis (Fig. 7) showed an increase of approximately $40 \%$ in actin content after treatment with $10^{-6} \mathrm{M}$ ATRA.

\section{Discussion}

The present study confirms and extends previous results (Wouters et al. 1992) showing that liarozole potentiates the effects of ATRA. To study this synergism we used MCF-7 cells. MCF-7 cell cultures have been shown to exhibit a profound heterogeneity (Yang et al. "1977: Barkley Butler et al. 1986). For example, Resnicoff et al. (1987) showed that MCF-7 cells consist of different subpopulations, which originate from a single clone. Moreover, there exist several clones of this cell line which exhibit biological and phenotypical differences. The MCF-7 cell line used in this study consists of a subpopulation of small cells and a subpopulation of large cells. The phenotype of these MCF-7 cells was evaluated by immunocytochemistry and revealed a lack of vimentin filaments and estrogen receptor expression, albeit heterogeneously. 
Since its establishment the MCF-7 cell line (Soule et al. 1973) consists of several size variants. The relative numbers of small and large cells depends on the passages used (Yang et al. 1977). The majority of early passages consist mainly of large cells, as described by Bani $e t$ al. (1994). In later passages (over 150), as used in this study, small cells have outnumbered the large cells. The heterogeneity within the cell line implies different responsiveness to nutrients. mitogenic and differentiation-inducing signals. At high concentration. ATRA changed the balance between large and small cells. At $10^{-6} \mathrm{M}$ ATRA, large cells by far outnumbered the small cells, but the effect was concentration-related. At concentrations of $10^{-8} \mathrm{M}$ and $10^{-7} \mathrm{M}$ ATRA. small cells outnumbered the large cells, comparable to control cultures.

Figure 7: Two-dimensional gel electrophoresis of total protein from equal numbers of control cells (a) and cells treated with $10^{-6}$ M ATRA (b). - A Actin: cytokeratins 8,18 and 19 are indicated by their number according to the catalog of Moll et al. (1982).

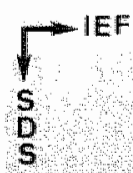

18

$$
\text { A } 19
$$

10

A 19 
As shown by BrdU incorporation studies, the antiproliferative effects of ATRA on MCF-7 cells were potentiated by liarozole, as indicated previously by means of an MTT assay (Wouters et al. 1992). The immunocytochemical detection of BrdU enabled the quantification of the differential ATRA-sensitivity in the subpopulations of small and large cells. The combination of liarozole $\left(10^{-6} \mathrm{M}\right)$ with $10^{9} \mathrm{M}$ and $10^{-8} \mathrm{M}$ ATRA showed similar BrdU uptake rates for both cell populations. Thus, liarozole is able to potentiate the effects of ATRA to the same extent in both cell populations. Liarozole was unable to potentiate the effect of $10^{-6} \mathrm{M}$ ATRA in large cells. This favours our hypothesis that liarozole potentiates the antiproliferative effects of ATRA via inhibition of its catabolism.

The synergism between liarozole and ATRA was observed on their differentiation-inducing effect on the heterogeneous $\mathrm{MCF}$ - 7 cell population. As recently described by Bani Sacchi $e t$ al. (1994), E-cadherin staining is closely related to this morphological heterogeneity. The subpopulation of small cells showed a clear E-cadherin staining along the cell membranes. In contrast. in the subpopulation of large cells. E-cadherin staining was faint and solely localized in the cytoplasm. However, upon treatment with ATRA. E-cadherin staining was increased at the cellular membrane of both cell populations. These results are similar to those recently described for the SK-BR-3 human breast cancer cell line (Anzano et al. 1994) and suggest induction of differentiation. The increased E-cadherin staining at the junctional complex was concomitant with the observed cytoskeletal changes. This is not surprising in light of the association of the cytoskeleton with cell-cell junctions (Takeichi, 1991: Gumbiner, 1993). Liarozole potentiated these ATRA-induced effects. The increased E-cadherin staining at cell-cell contacts might also have functional effects on the cells, as for example increased cell aggregation as seen for the invasive MCF-7/6 cell line variant after ATRA treatment (Bracke et al. 1994). Given that E-cadherin expression is correlated with a differentiated non-invasive phenotype (Takeichi, 1991) and that ATRA enhances the functionality of Ecadherin (Bracke et al. 1994), liarozole might exert anti-metastatic effects in vivo (Stearns et al., 1993), where the drug has been shown to have retinoid activity (Van Wauwe et al. 1992; Mahler et al. 1993). This would have important clinical implications for the use of liarozole in the treatment of prostate cancer, in which decreased expression of E-cadherin has been correlated with tumor progression (Umbas et al., 1992).

The expression of desmosomal proteins (desmoglein and desmoplakins I \& II) was related to both $\mathrm{MCE}-7$ cellular subtypes. but ATRA treatment had no influence on their staining. Also in FRIC B fetal rat intestine cells the expression of desmoplakins I \& II did not change upon retinoid treatment (Plateroti et al., 1993). 
The changes in cell morphology and at the level of cell-cell junctions were accompanied by a profound reorganization of the cytoskeleton. ATRA treatment changed the organization of cytokeratin filaments so much that a clear network of cytokeratin filaments became visible. accompanied by a $50 \%$ down-regulation of cytokeratin expression. Liarozole potentiated this ATRA-induced reorganization of cytokeratin filaments. These effects were also seen when MCF-7 cells were treated with the neurohypophyseal peptide oxytocin (Cassoni el al. 1994). Cytokeratin modulation by liarozole was also observed concomitant with a shift in the differentiation status in prostate tumors (Smets et al. 1995). Down-regulation of cytokeratins in cancer cells is considered as an induction of differentiation by some authors (Kopan and Fuchs, 1989: Tomic et al., 1990).

Analogous to the changes described for cytokeratins. ATRA had a profound effect on actin organization. ATRA induced numerous actin-containing stress fibers and focal adhesions. This effect, which also suggests induction of differentiation (Lehtonen et al.s 1983; Ng et al. 1985), was enhanced by liarozole. Furthermore, the occurrence of actin-containing stress fibers has been correlated with anti-metastatic properties (Volk et al. 1984). Similar changes in the organization of actin fibers have been described in connection with ATRA-treated F9 testicular teratocarcinoma cells (Lehtonen et al.. 1983). FRIC B fetal rat intestine cells (Plateroti et al. 1993) and UMR 106-06 osteogenic sarcoma cells (Ng et al., 1985). ATRA has been found to stimulate actin polymerization (Murali Krishna Rao, 1985). In contrast to downregulation of cytokeratins, actin content was up-regulated upon ATRA treatment.

In conclusion, liarozole not only potentiated the antiproliferative effects of ATRA on MCF-7 cells, but also ATRA-induced differentiation. This potentiation is most probably due to inhibition of ATRA catabolism and agrees with previously obtained biochemical findings on the synergistic interaction of ATRA and liarozole in MCF-7 cells.

\section{Acknowledgements}

We are very grateful to Guy Daneels, Jannie Ausma and Helma Kuijpers for expert technical assistance and Lambert Leijssen. Hans Henderickx and Guy Jacobs for the photographic layout. 


\section{References}

Anzano, M.A., Byers, S.W., Smith, J.M., Peer, C.W. Mullen, L.T., Brown, C.C." Roberts, A.B., and Sporn, M.B. Erevention of breast cancer in the rat with 9-cis-retinoic acid as a single agent and in combination with tamoxifen. Cancer Res. 54: 4614-4617. 1994.

Bani Sacchi, T, Bani, D., Brandi, M.L., Falchetti. A., and Bigazzi, M. Relaxin influences growth. differentiation and cell-cell adhesion of human breast cancer cells in culture. Int. J. Cancer 57 : 129-134. 1904.

Bani. D., Riwa, A., Bigazzi, M., and Bani Sacchi, T. Differentiation of breast cancer cells in vitro is promoted by the concurrent influence of myoepithelial cells and relaxin. Br. J. Cancer 70: 900904. 1994.

Barkley Butler, W., Berlinski, P.J., Hillman, R.M., Kelsey, W.H., and Toenniges, M.M. Relation of in vitro properties to tumorigenicity for a series of sublines of the human breast cancer cell line MCF-7. Cancer Res. 46: 6339-6348. 1986.

Bracke, M.E. Vermeulen, S.J., Bruyneel, E.A., Vennekens, K.M., De Bruyne, G.K, van Roy. F.M., and Mareel, M.M. The invasion suppressor function of Ercadherin in mammary epithelioid cells. In: Schmitt. M. et al. (eds.). Prospects in diagnosis and treatment of breast cancer, pp. 107-115. Amsterdam; Elsevier Science Publishers, 1994.

Broers, J.L.V., Carney, D.N., Klein Rot, M., Schaart, G., Lane, E.B., Vooijs, G.P., and Ramaekers, E.C.S. Intermediate filament proteins in classic and variant types of small cell lung carcinoma cell lines: a biochemical and immunochemical analysis using a panel of monoclonal and polyclonal antibodies. J. Cell Sci. 83: 37-60, 1986.

Cassoni. P., Sapino, A., Negro, F., and Bussolati, G. Oxytocin inhibits proliferation of human breast cancer cell lines. Virchows Archiv. 425: 467-472, 1994 .

Chytil. F. Retinoic acid: Biochemistry. pharmacology, toxicology. and therapeutic use. Pharmacol. Rev, 36: 935-1005. 1984,

Cupo, J.F., Lidgard, G.P. and Lichtman, W.F. A high resolution two.dimensional gel electrophoresis and silver staining protocol demonstrated with nuclear matrix proteins. Electrophoresis 11: $500-504,1990$.

De Coster. R., Wouters, W. Van Ginckel, R., End, D. Krekels, M., Coene, M.-C. and Bowden, C. Experimental studies with liarozole (R 75251): an antitumoral agent which inhibits retinoic acid breakdown. J. Steroid. Biochem. Mol. Btol 43: 197-201, 1992.

Dijkman, G.A., Van Moortselaar, R.J.A., Van Ginckel, R., Van Stratum, P., Wouters, L., Debruyne, F.M.J., Schalken, J.A., and De Coster, R. Antitumoral effects of liarozole in androgen-dependent and -independent R3327-Dunning prostate adenocarcinomas. J. Urol. 151: 217-222, 1994.

Fleming, S. Cell adhesion and epithelial differentiation. J. Pathol. 164: 95-100, 1991. 
Franke, W.W. Moll, R. Müller. H., Schmid. E. Kuhn, C. Krepler, R., Artlieb. U., and Denk, H. Immunocytochemical identification of epithelium-derived human tumors with antibodies to desmosomal plaque proteins. Proc. Natl. Acad. Sci. U.S.A. 80: 543-547. 1983.

Giguère. V. Retinoic acid receptors and cellular retinoid binding proteins: complex interplay in retinoid signaling. Endocr. Rev. 15: 61-79, 1994.

Gumbiner, B.M. Proteins associated with the cytoplasmic surface of adhesion molecules. Neuron 11: 551-564, 1993.

Helige, C., Smolle, J., Zellnig, G., Hartmann, E.. Fink-Puches, R., Kerl, H., and Tritthart, H.A. Inlibition of K1735-M2 melanoma cell invasion in vitro by retinoic acid. Clin. Exp. Metastasis 11: 409-418, 1993.

Kopan, R., and Fuchs. E. The use of retinoic acid to probe the relation between hyperproliferation in normal and malignant epidemal cells. J. Cell Btol. 109: 295-307; 1989.

Laemmli, U.K. Cleavage of structural proteins during the assembly of the head of bacteriophage T4. Nature (London) 227: 680-685, 1970.

Lehtonen, E., Lehto. V.-P., Badley, R.A., and Virtanen, I. Formation of vinculin plaques precedes other cytoskeletal changes during retinoic acid-induced teratocarcinoma cell differentiation. Exp. Cell Res. 144: 191-197, 1983.

Lotan, R. Effects of vitamin A and its analogs (retinoids) on normal and neoplastic cells. Biochim. Biophys. Acta 605: 33-91, 1980.

Mahler, C., Verhelst. J.a and Denis, L. Ketoconazole and liarozole in the treatment of advanced prostatic cancer. Cancer 71: 1068-1073, 1993.

Mangelsdorf, D.]. Umesono, K. and Evans, R.M. The retinoid receptors. In: Sporn, M.B., Roberts, A.B., Goodman, D.S. (eds.), The Retinoids. Biology. Chemistry, and Medicine. Ed. 2. pp. 319-349. New York: Raven Press, Ltd., 1994.

Moll, R., Franke, W.W., and Schiller, D.L. The catalog of human cytokeratins: patterns of expression in normal epithelia, tumors and cultured cells. Cell $31: 11-24,1982$.

Murali Krishna Rao, $\mathrm{K}$. Phorbol esters and retinoids induce actin polymerization in human leukocytes. Cancer Lett. 28: 253-262, 1985.

Ng, K.W., Livesey, S.A. Collier. F, Gummer, P.R., and Martin, T.J. Effect of retinoids on the growth, ultrastructure, and cytoskeletal structures of mallignant rat osteoblasts. Cancer Res, 45:5106. 5113. 1985.

North. A.J., Gimona, M., Lando, Z, and Small, J.V. Actin isoform compartments in chicken glzzard smooth muscle cells. J. Cell Sci. 107: 445-455. 1994. 
OFarrell, $\mathrm{P}, \mathrm{H}$. High resolution two-dimensional electrophoresis of proteins. I. Biol. Chem. 250:4007. 4021.1975 .

Plateroti. M., Sambuy, Y., Nobili, F, Bises, G, and Perozzi, G. Expression of epithelial markers and retinoid-binding proteins in retinol- or retinoic acid-treated intestinal cells in vitro. Exp. Cell Res. 208: 137-147, 1993.

Ramaekers, F., Huysmans, A., Schaart, G, Moesker, O., and Vooifs, P. Tissue distribution of keratin 7 as monitored by a monoclonal antibody. Exp. Cell Res. 170:235-249, 1987.

Resnicoff, M., Medrano, E.E., Podhajcer, O.L., Bravo, A.I. Bover, L., and Mordoh. I. Subpopulations of MCF7 cells separated by Percoll gradient centrifugation: A model to analyze the heterogeneity of human breast cancer. Proc. Natl. Acad. Sci. U.S.A. 84: 7295-7299, 19.87.

Rutka. J.T., De Armond, S.J., Giblin, J., McCulloch, J.R., Wilson, C.B., and Rosenblum, M.L. Effect of retinoids on the proliferation. morphology and expression of glial fibrillary acidic protein of an anaplastic astrocytoma cell line. Int. J. Cancer 42: 419-427, 1988.

Schaafsma, H.E. Ramaekers, F., van Muijen. G.N.P., Ooms, E.C.M., and Ruiter, D.J. Distribution of cytokeratin polypeptides in epithelia of the adult urinary tract. Histochemistry 91: 151-159, 1989.

Schaart, G., Pleper, F.R. Kuypers, H.J.H., Bloemendal, H, and Ramaekers, F.C.S. Baby hamster kidney (BHK-21/C13) cells can express striated muscle type proteins. Differentiation 46: 105-115. 1991.

Schmelz, M., Duden, R., Cowin. P. and Franke, W.W. A constitutive transmembrane glycoprotein of $M_{r} 165000$ (desmoglein) in epldermal and non-epidermal desmosomes. I. Biochemical identification of the polypeptide. Eur. J. Cell Biol. 42:177-183, 1986.

Schmidt, A. Heid, H.W., Schäfer, S., Nuber, U.A. Zimbelmann, R., and Franke, W.W. Desmosomes and cytoskeletal architecture in epithelial differentiation: cell type-specific plaque components and intermediate filament anchorage. Eux. J. Cell Biol. 65: 229-245, 1994.

Shimoyama, Y., Hirohashi, S., Hirano, S. Noguchi, M., Shimosato, Y. Takeichi, M." and Abe, O. Cadherin cell-adhesion molecules in human epithelial tissues and carcinomas. Cancer Res. 49: 21282133. 1989.

Smets, G. Van Ginckel، R. Daneels، G. Moeremans, M. Van Wauwe, J., Coene, M.-C., Ramaekers, F.C.S., Schalken, J.A., Borgers, M., and De Coster, R. Liarozole, an antitumor drug, modulates cytokeratin expression in the Dunning AT-6sq prostatic carcinoma through in situ accumulation of all-r.rans-retinoic acid. Prostate 27: 129-140, 1995.

Soule, H.D., Vasquez, J. Long, A., Albert, S., and Brennan. M. A human cell line from a pleural effusion derived from a breast carcinoma. J. Natl. Cancer Inst. 51: 1409-1416, 1973.

Stearns. M.E.. Wang, M.. and Fudge, K. Liarozole and $13 \cdot$ cis-retinoic acid anti-prostatic tumor activity. Cancer Res. 53: 3073-3077. 1993. 
Takeichi, M. Cadherin cell adhesion receptors as a morphogenetic regulator: Sctence 251: 1451-1455. 1991.

Tomic, M. Jüarg. C.K. Epstein, H.S.,Freedberg, I.M., Samuels. H.H., and Blumenberg, M. Nuclear receptors for retinoic acid and thyroid hormone regulate transcription of keratin genes. Cell Regul. 1: $965-973,1990$.

Umbas, R., Schalken. J.A., Aalders, T.W., Carter, B.S., Karthaus, H.E.M., Schaafsma, H.E " Debruyne. F.M.J., and Isaacs, W.B. Expression of the cellular adhesion molecule E-cadherin is reduced or absent in high-grade prostate cancer. Cancer Res. 52: 5104-51.09. 1992.

Van Ginckel ${ }_{\text {R. }}$ De Coster, R., Wouters, W. Vanherck, W., van der Veer, R., Goeminne, N.. Jagers, E.. Van Cauteren, H., Wouters, L.. Distelmans, $W_{*}$ and Janssen, P.A.J. Antitumoral effects of R 75251. on the growth of transplantable R3327 prostatic adenocarcinoma in rats. Prostate 16:313-323. 1990.

Van Wauwe, J.P., Coene. M.-C., Goosens, J., Cools, W., and Monbaliu, J. Effects of cytochrome P450 inhibitors on the in vino metabolism of all-trans-retinoic acid in rats. J. Pharmacol. Exp. Ther. 252: 365-369. 1990.

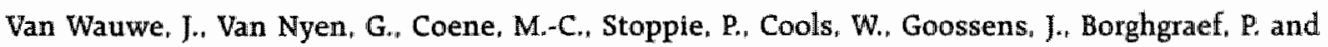
Janssen, P.A.J. Liarozole, an inhibitor of retinoic acid metabolism, exerts retinoid-mimetic effects in vivo. J. Pharmacol. Exp. Ther. 261: 773-779. 1992.

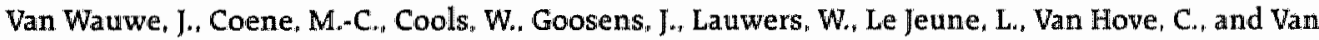
Nyen, G. Liarozole fumarate inhibits the metabolism of 4-keto-all-trans-retinoic acid. Biochem. Pharmacol. 47: 737-741, 1994.

Volk. T., Geiger B., and Raz, A. Motility and adhesive properties of high and low metastatic murine neoplastic cells. Cancer Res. 44: 811-824, 1984.

Wolf, G. Multiple functions of vitamin A. Physiol. Rev. 64: 873-937, 1984.

Wouters, W., van Dun, J., Dillen, A., Coene, M.-C., Cools, W. and De Coster, R. Effects of liarozole, a new antitumor compound, on retinoic acid-induced inhibition of cell growth and on retinoic acid metabolism in MCF-7 human breast cancer cells. Cancer Res. 52: 2841-2846. 1992.

Yang, N.-S., Soule. H.D. and McGrath, C.M. Expression of murine tumor virus-related antigens in human breast carcinoma (MCF-7) cells. J. Natl. Cancer Inst. 59: 1357-1367. 1977. 
क्ष : 


\section{Liarozole-fumarate potentiates the all-trans-retinoic acid-induced differentiation of F9 teratocarcinoma cells by inhibition of the all-trans-retinoic acid catabolism}

Submitted for publication.

Gerda Smets ${ }^{1}$, Jimmy Van heusden ${ }^{2}$, Heidi Païvarinne ${ }^{1}$, Marita D.W.G. Krekels ${ }^{1}$, Frans C.S. Ramaekers ${ }^{2}$, and Walter Wouters ${ }^{1}$

${ }^{1}$ Department of Oncology, Janssen Research Foundation. Turnhoutseweg 30, B-2340 Beerse, Belgium: ${ }^{2}$ Department of Molecular Cell Biology \& Genetics. Uniwersity of Maastricht, P.O. Box 616,6200 MD Maastricht, The Netherlands

Abstract

F9 teratocarcinoma cells are nullipotent embryonic carcinoma cells that differentiate upon treatment with all-trans-retinoic acid (ATRA). To evaluate the potentiating effects of liarozole-fumarate on ATRA treatment, the present study was focused on its potentiation of ATRA-induced differentiation and on the inhibition of ATRA catabolism by liarozole-fumarate in F9 monolayer cell cultures. As markers for differentiation, the expression of E-cadherin. N-CAM, vimentin, cytokeratins 8,18 and 19 , actin as well as laminin and 
collagen IV was analyzed by immunocytochemistry. Treatment with ATRA at concentrations ranging from $10^{-11} \mathrm{M}$ to $10^{-6} \mathrm{M}$ was compared to treatment with liarozole-fumarate at $10^{-6} \mathrm{M}$ or $10^{-5} \mathrm{M}$, or to the combined treatment with ATRA and liarozole-fumarate. Liarozole-fumarate alone did not induce any phenotypic shift. ATRA between $10^{-7} \mathrm{M}$ and $10^{-6} \mathrm{M}$ changed expression of all markers, while lower concentrations only influenced laminin and collagen IV expression. Whereas $10^{-8} \mathrm{M}$ ATRA was not capable of inducing or enhancing the expression of most markers, combination of $10^{-8} \mathrm{M}$ ATRA with $10^{-6} \mathrm{M}$ or $10^{-5} \mathrm{M}$ liarozole-fumarate induced a F9 phenotype shift comparable to that obtained with $10^{-7} \mathrm{M}$ ATRA alone. Liarozole-fumarate inhibited ATRA catabolism with an $\mathrm{IC}_{50}$ of $3 \mu \mathrm{M}$. These results supports the hypothesis that liarozole-fumarate potentiates ATRA-induced differentiation in F9 through inhibition of the ATRA catabolism. The 10-fold higher IC 50 value in $\mathrm{F9}$ as compared to the previously obtained value in MCF-7 $\left(\mathrm{IC}_{50}=0.3 \mu \mathrm{M}\right.$, Krekels et al., 1997), could be explained by differences in uptake of both ATRA and liarozole-fumarate. About 5-fold less ATRA and 5fold less liarozole-fumarate was taken up by F9 cells as compared to MCF-7 cells.

\section{Introduction}

Liarozole-fumarate is currently in phase III clinical trials for the treatment of relapsed prostate cancer. Pre-clinical animal models showed that liarozole-fumarate reduced tumor growth of androgen-dependent and androgen-independent Dunning $R 3327$ rat prostate adenocarcinoma cells (Van Ginckel et al. 1990; De Coster et al., 1992: Dijkman et al. 1994; Smets et al. 1995). In an in vitro model with MCF-7 human breast carcinoma monolayers, both the antiproliferative and the differentiation-inducing effect of all-trans-retinoic acid (ATRA) were potentiated by liarozole-fumarate (Van heusden et al., 1996) with a concomitant decrease of ATRA metabolites (Wouters et al., 1992; Krekels et al. 1997).

Both in biological models as well as in patients, the antitumoral effects of liarozole-fumarate are supposed to be linked to its retinoid-mimetic effects (Van Wauwe et al. 1992; Mahler et al. 1993). Liarozole-fumarate blocks the catabolic pathway of ATRA, by inhibition of the cytochrome P450-dependent 4-hydroxylation of ATRA and by inhibition of mono- 
hydroxylation reactions of 4-oxo-ATRA (Van Wauwe et al., 1990, 1994). This might be the mechanism of action through which liarozole-fumarate enhances endogenous plasma and tumor ATRA levels and also increases the plasma half-life of exogenously administered ATRA (Van Ginckel et al., 1990; De Coster et al., 1992: Smets et al.. 1995). As ATRA is a wellknown inducer of differentiation, the observed induction of differentiation in tumors and tumor cell lines upon treatment with liarozole-fumarate (Smets et al. 1995: Van heusden et al. 1996) might thus be linked to the inhibition of ATRA catabolism by liarozole-fumarate. To further illustrate the differentiation-enhancing capacities of the liarozole-fumarate-ATRA chain. the present study was undertaken to evaluate the ATRA-induced differentiation in combination with liarozole-fumarate in F9 teratocarcinoma cells. as yet the best documented in vitro model for biochemical as well as morphological ATRA-linked differentiation. F9 is a nullipotent embryonic carcinoma cell line incapable to differentiate spontaneously in vitro. However, after treatment of $F 9$ with ATRA, a process of differentiation is induced resembling the segregation of cell layers into visceral or parietal endoderm during gastrulation. In normal embryogenesis the visceral endoderm is the cell mass remaining associated with the embryoid body in the blastocyst. whereas the parietal endoderm is formed by migratory cells colonizing the inner surface of normal trophectoderm. The type of cell culture system used, influences the patterns of gene expression (Martin and Evans. 1975; Strickland et al., 1976, 1978) and consequently, determines the development of cells with typical visceral endoderm- or parietal endoderm-like characteristics (Hogan et al., 1983). When F9 cells are cultured as small aggregates, treatment with ATRA will induce differentiation towards embryoid bodies consisting of a core of undifferentiated stem cells surrounded by a polarized epithelium of visceral endoderm, typically secreting $\alpha$-fetoprotein and the urokinase form of plasminogen activator (Hogan et al., 1981). On the contrary, in F9 monolayer cell cultures, ATRA treatment induces differentiation in a fraction of the cells towards fibroblast-like cells in a sequence that is considered to model the mammalian equivalent of the differentiation from stem cells of the inner cell mass to parietal endoderm (Burdsal et al. 1994). As such, a typical extraembryonic or parietal endoderm-type of differentiation is seen. characterized by the secretion of tissue plasminogen activator, the expression of cytokeratins or components of the thick basement membrane (Reichert's membrane) like laminin and collagen IV. Expression of cell adhesion molecules is embryologically and developmentally regulated and therefore, might serve as a morphogenetic marker in F9 differentiation upon ATRA treatment (Takeichi. 1991).

The present study focused on ATRA-induced differentiation of F9 cells, grown as monolayers on gelatinized culture plates and investigated the inhibition of ATRA catabolism by liarozole- 
fumarate. The potentiating effect of liarozole-fumarate on ATRA was monitored by evaluating the expression levels of E-cadherin. N-CAM, vimentin cytokeratins 8, 18 and 19. actin as well as laminin and collagen IV. The F9 data are discussed in view of data previously obtained in MCF-7 monolayers.

\section{Materials and Methods}

\section{Drugs and chemicals}

The fumarate salt of liarozole $\{ \pm$-5-1(3-chlorophenyl)( $1 \mathrm{H}$-imidazole-1-yl)methyll-1 $\mathrm{H}$-benzimidazole (E)2-butenedioate (2:3)\} (R085246), and ${ }^{34} \mathrm{C}$ Cliarozole-fumarate with a specific radioactivity of $882 \mathrm{MBq} /$ mmol were synthesized at the Janssen Research Foundation (Beerse, Belgium). ATRA (Serva, Heidelberg. Germany) and $\left[11,12 .{ }^{3} \mathrm{H}(\mathrm{N})\right] \mathrm{ATRA}$ (specific radioactivity of $1894.4 \mathrm{MBg} / \mathrm{mmol}$ )(DuPont NEN. Boston, MA. U.S.A.) were used in a dark room with yellow illumination. Stock solutions of liarozole-fumarate $(10 \mathrm{mM})$ and ATRA (4 mM) were prepared in ethanol and appropriately diluted in culture medium. Final solvent contentration in the cell cultures was always less than $0.5 \%$. All chemicals and solvents were of the highest purity available.

\section{Cell lines}

F9 mouse teratocarcinoma cells and MCF-7 human mammary carcinoma cells were purchased from the American Type Culture Collection (ATCC, Rockville, MD. U.S.A.). Both cell lines were cultured in Dulbecco's modified Eagle's medium (DMEM), containing 4.5 g/iter glucose supplemented with 2 $\mathrm{mM}$ glutamine, $1 \mathrm{mM}$ sodium pyruvate, $50 \mu \mathrm{g} / \mathrm{ml}$ gentamycin and with $15 \%$ fetal bovine serum for $\mathrm{F} 9$. while $10 \%$ fetal bovine serum was added for MCF-7 (all cell culture reagents from Life Technologies, Ghent, Belgium). Cells were grown in a humidified incubator $\left(5 \% \mathrm{CO}_{2}, 95 \%\right.$ air) at $37^{\circ} \mathrm{C}$ and were Mycoplasma free as tested by the Mycoplasma T.C. kit (Gen-Probe Incorporated. CA. U.S.A.). For the experiments described in this study. $F 9$ and MCF-7 cells between 10 and 15 passages were used.

\section{Induction of differentiation (according to induction of differentiation in MCF-7 cells: Van heusden et al., Eur. J. Cell Biol.. 71: 89-98, 1996) CBLL CULTURE SYSTEM}

F9 cells were plated onto Chamber Slides ${ }^{\text {tad }}$ (Nunc Inc., Naperville, IL, U.S.A.) at a concentration of 500 cells/chamber. The Chamber Slides ${ }^{\text {ts }}$ were pretreated with $20 \mu \mathrm{g} / \mathrm{ml}$ poly-L-lysine and subsequently coated with $0.1 \%$ gelatin. Cells were allowed to attach for $24 \mathrm{~h}$ before the addition of the drugs and. then, incubated for 3 days under the following test conditions: ATRA at concentrations from $10^{-11} \mathrm{M}$ to $10^{-6} \mathrm{M}$. liarozole-fumarate at concentrations from $10^{-8} \mathrm{M}$ to $10^{-5} \mathrm{M}$ and liarozole-fumarate $\left(10^{-6} \mathrm{M}\right.$ or $10^{-5} \mathrm{M}$ ) in combination with ATRA from $10^{-11} \mathrm{M}$ to $10^{-7} \mathrm{M}$. 


\section{MMUNOCYTOCHEMISTRY}

Cells grown with or without test compounds for 3 days were washed twice with serum free culture medium. Cells were fixed in methanol $\left(5 \mathrm{~min} .20^{\circ} \mathrm{C}\right.$ ) and acetone $110 \mathrm{~s}, 20^{\circ} \mathrm{C}$ ) and subsequently, airdried. Aspecific antibody binding was prevented by blocking in $5 \%$ normal goat serum in $10 \mathrm{mM}$ PBS (pH 7.4) for $1 \mathrm{~h}$. Then cells were incubated for $1 \mathrm{~h}$ at room temperature in a dark moist chamber with the primary monoclonal antibody. After a series of washing steps in PBS. bound antibodies were visualized with the immunofluorescence technique using a secondary fliorescein isothlocyanate (FTC)labeled goat anti-mouse IgG (Southern Biotechnology Associates. Birmingham. AL. U.S.A.). Slides were air-dried and mounted in Mowiol (Hoechst. Frankfurt. Germany) containing I\% propidium lodide. The characteristics and references of the primary antibodies used in this study are summarized in. Table I.

Table I: Primary antibodies used for immunacytochemistry on F9 cells

\begin{tabular}{|c|c|c|c|c|}
\hline Antigen recognized & Antibody & Dilution & lg subclass & Source : Primary \\
\hline cytokeratin 8 & LEA 1 & $1 / 1100$ & $\operatorname{Lg} G_{1}$ (monclonal) & E.B. Lane. Dundee, U.K. \\
\hline gytokeratin 18 & RCE53 & $1 / 100$ & IgG, (nonclonal) & P. Ramatekers, Mastricht. The Netherlands \\
\hline cytokeratin 19 & $\mathrm{LP} 2 \mathrm{~K}$ & $1 / 100$ & $\operatorname{lgG}_{1}$ (monclonal) & E.B. Lane, Dundee, U.K. \\
\hline wimentirs & $\mathrm{RV} 202$ & undiluted & $\operatorname{lgG}_{1}$ (monclonal) & E Kamaekers. Masstricht The Netherlands \\
\hline actin & Bactin & $1 / 1000$ & $\operatorname{lgG}_{1}$ (monclonal) & Sigma immunochemicals. St. Loulis. MO U.S. H \\
\hline collagen IV & MSE7 & undiluted & $\operatorname{lgG}$ (monclonal) & DSHB, lowa City, IA, U.S.A. \\
\hline laminin & 186103 & $1 / 200$ & Ig (polyclonal) & DSHB, fowa City, IA U.S.A. \\
\hline E-cadherin & $\mathrm{ECCD}-2$ & $10 \mathrm{Hg} / \mathrm{ml}$ & IgG, (monclonal) & Zymed. San Erancisco. U.S.A. \\
\hline $\mathrm{N} \sim \mathrm{CAM}$ & cil. 0008 & $10 \mu \mathrm{gg} / \mathrm{ml}$ & $\lg G$ frnonclonall & Cederlane ontarlo, U.S.A. \\
\hline
\end{tabular}

\section{Inhibition of retinoic acid catabolism (according to $\mathrm{IC}_{50}$ determination} for MCF-7: Krekels et al., Br. J. Cancer. 75: 1098-1104. 1997)

\section{Celd Culture}

F9 cultures were treated for $24 \mathrm{~h}$ with $10^{\circ} \mathrm{MATRA}$. Cells were then washed twice with $25 \mathrm{ml}$ culture medium and trypsinized. Cells were resuspended at $4 \times 10^{6}$ cells $/ \mathrm{mil}$ in DMEM without phenol red. containing $1 \mathrm{~g} / \mathrm{liter}$ glucose and supplemented with $2 \mathrm{mM}$ glutamine, $1 \mathrm{mM}$ sodium pyruvate. $50 \mu \mathrm{g} /$ $\mathrm{ml}$ gentamycin and $10 \%$ heat-inactivated fetal bovine serum (DMEM*) (all reagents from Life Technologies). Allquots $(450 \mu)$ ) of this cell suspension were pre-incubated for 5 min at $37^{\circ} \mathrm{C}$ with liarozole-fumarate or the solvent in glass test tubes. Incubation was then continued for $90 \mathrm{~min}$ in the presence of $25 \mu]\left[11,12{ }^{3} \mathrm{H}(\mathrm{N})\right] \mathrm{ATRA}$. At the end of the respective incubation, the reaction mixture was analyzed for retinoic acid metabolites using a quantitative microcolumn assay. 


\section{MICROCOLUMN ASSAY}

The reaction mixture was mixed with $2 \mathrm{ml} 100 \%$ acetonitrile. After centrifugation for $10 \mathrm{~min}$ at $780 \mathrm{~g}$ the resulting protein-free supernatant was acidified with $2.5 \mathrm{ml} 40 \mathrm{mM}$ acetic acid. The acidified liquid was applied to a $3 \mathrm{mll}$ CI8 Bond Elut LRC Column (Varian. Harbor City, CA. U.S.A.') wnder a vacuum of $127 \mathrm{mmHg}$ using a VAC ELUT SPS-24 and the effluent (fraction 1) was collected. The column was then eluted with $1 \mathrm{ml}$ of $40 \%$ acetonitrle in water (fraction 2). Fractions 1 and 2 were combined and the collected effluent was counted for radioactivity in a Tri-carb 4530 liquild scintillation analyzer. Optiphase "HiSafell" (Wallac. Milton Keynes. United Kingdom) was used as a scintillator. Experiments were performed three times and duplicate values were obtained for each data point. $\mathrm{IC}_{50}$ values were calculated by linear regression analysis.

\section{QUANTIFICATION OF ATRA AND LIAROZOLE-FUMARATE UPTAKE IN MCF-7 AND IN F9 CELLS}

F9 and $\mathrm{MCF}-7$ cell cultures were treated for $24 \mathrm{~h}$ with $10^{-6} \mathrm{M}$ ATRA. Cells were then washed twice with $25 \mathrm{ml}$ culture medium, harvested and resuspended at $4 \times 10^{6} \mathrm{cells} / \mathrm{ml}$ in DMEM*. Aliquots $(2 \mathrm{ml})$ of this cell suspension were incubated for $2 \mathrm{~h}$ at $37^{\circ} \mathrm{C}$ with $\left[{ }^{14} \mathrm{C}\right.$ liarozole-fumarate at $10^{-5} \mathrm{M}$ and $10^{-6} \mathrm{M}$ or with [11, $\left.12^{3} \mathrm{H}(\mathrm{N})\right]$ ATRA at $10^{-7} \mathrm{M}$ and $10^{-8} \mathrm{M}$. Cells were washed twice with $2 \mathrm{~m} 1 \mathrm{PBS}$ by centrifugation at $4{ }^{\circ} \mathrm{C}$. The final cell pellet was solubilized for $30 \mathrm{~min}$ at $20^{\circ} \mathrm{C}$ with $1 \mathrm{ml} 5 \%$ Triton X-100; $10 \mathrm{ml}$ optiphase "Hi Safe II" sicintillation liquid (Wallac, Milton Keynes. United Kingdom) was added and the total fraction counted in a Packard Tri-carb 4530 liquid scintillation analyzer.

The ratio for uptake in $\mathrm{MCF}$-7 versus uptake in $\mathrm{F} 9$ was then calculated. Experiments were performed three times and triplicate walues were obtained for each data point.

\section{Results}

\section{Liarozole-fumarate enhances ATRA-induced differentiation in F9 cells} GENERAL MORPHOLOGY

The differentiation-inducing effect of ATRA was tested in a concentration range from $10^{-11} \mathrm{M}$ to $10^{-6} \mathrm{M}$. Liarozole-fumarate was studied at $10^{-6} \mathrm{M}$ and at $10^{-5} \mathrm{M}$. as a single treatment or in combination with the respective ATRA concentrations. Upon treatment with ATRA at $10^{-7} \mathrm{M}$ and at $10^{-6} \mathrm{M}$, all cells developed a lattened morphology but only a minority of cells $( \pm 20 \%$ ) acquired a phenotype that resembled neuronal cells characterized by long cellular branched axon-like processes (Figs. 3. 4, 5). From $10^{8} \mathrm{M}$ on, the induction of the neuronal-like differentiation was less than $3 \%$. Liarozole-fumarate alone did not induce any change in the basal F9 mor phology. However, the combined treatment of $10^{-6} \mathrm{M}$ or $10^{-5} \mathrm{M}$ liarozole-fumarate with ATRA at $10^{.9} \mathrm{M}, 10^{-8} \mathrm{M}$ and $10^{-7} \mathrm{M}$ potentiated the ATRA effect. As an example, the combined treatment of $10^{-6} \mathrm{M}$ liarozole-fumarate with ATRA at $10^{8} \mathrm{M}$ resulted in a cell 
culture composed of about $20 \%$ neuronal-like cells mixed with otherwise undifferentiated cells, comparable to the image after treatment with single ATRA treatment at $10^{-7} \mathrm{M}$.

\section{EXPRESSION OF LAMININ AND COLLAGEN IV}

Treatment with $10^{-8} \mathrm{M}$ to $10^{-6} \mathrm{M}$ ATRA induced expression of the extracellular matrix proteins. laminin (Fig. 1) and collagen IV (Fig, 2), in all cells at $10^{-6} \mathrm{M}$ to about $50 \%$ of the cells at $10^{-8} \mathrm{M}$. However, at $10^{-9} \mathrm{M}$ the number of laminin and collagen IV immunopositive cells sharply decreased to about $20 \%$. At $10^{-10} \mathrm{M}$ ATRA. only very few cells $(<1 \%)$ did immunostain. whereas at $10^{-11} \mathrm{M}$ no cells were found immunopositive anymore. Cells treated with vehicle or with $10^{6} \mathrm{M}$ or $10^{-5} \mathrm{M}$ liarozole-fumarate were only weakly immunostained at their cell border comparable to control conditions. However treatment with the combination of $10^{-6} \mathrm{M}$ or $10^{-5} \mathrm{M}$ liarozole-fumarate and ATRA at $10^{-9} \mathrm{M} \cdot 10^{-8} \mathrm{M}$ and $10^{-7} \mathrm{M}$ potentiated the ATRA effect. As an example, the treatment with $10^{-9} \mathrm{M}$ ATRA together with $10^{-6} \mathrm{M}$ or $10^{-5} \mathrm{M}$ liarozole-fumarate increased the matrix protein expression in about $50 \%$ cells. resembling the image obtained with $10^{-8} \mathrm{M}$ ATRA alone. There was no differential immunostaining between the cells with the neuronal phenotype and the other cells.

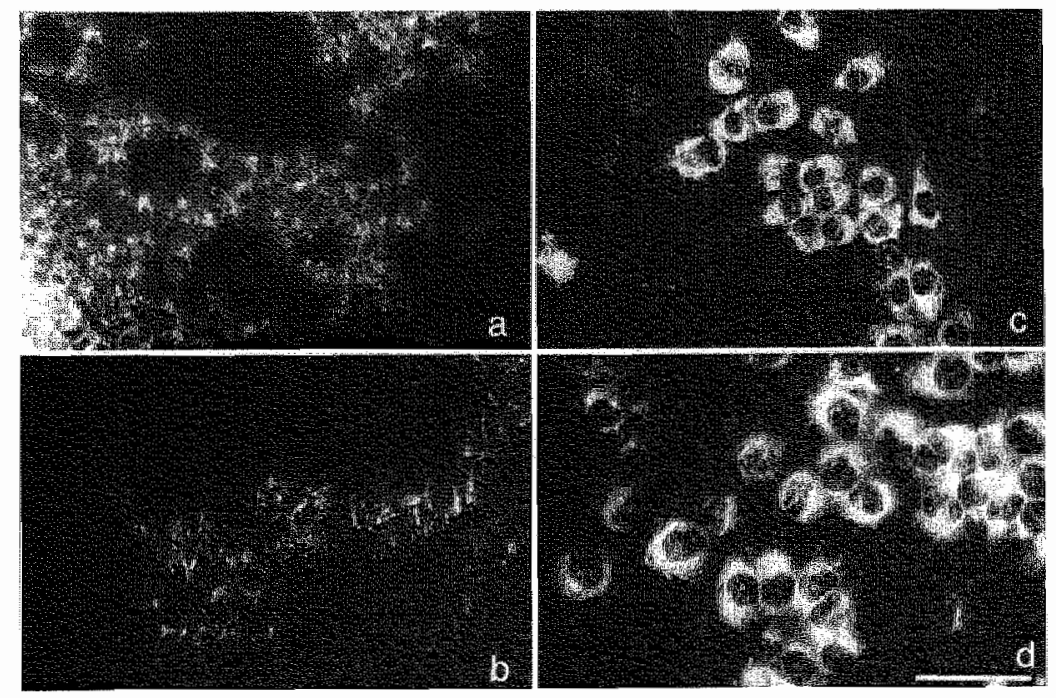

Figure 1: Expression of laminin in F9 monolayer cell cultures in vehicle treated cells (a), in $10^{-6} \mathrm{M}$ liarozole-fumarate treated cells (b), in $10^{-7} \mathrm{M}$ ATRA treated cells (c), in $10^{-8} \mathrm{MATRA}+10^{-6} \mathrm{M}$ liarozole-fumarate treated cells (d). - Bar $20 \mu \mathrm{m}$. 


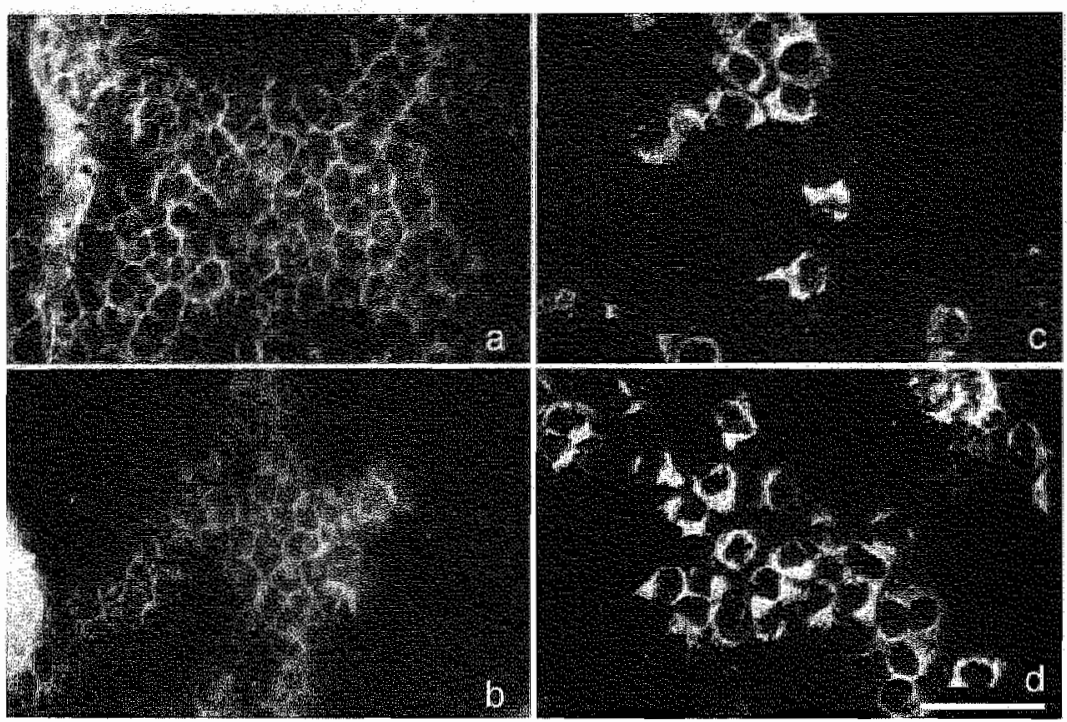

Figure 2: Expression of collagen $\| \mathrm{V}$ in $\mathrm{F} 9$ monolayer cell cultures in vehicle treated cells (a), in $10^{-6} \mathrm{M}$ liarozole-fumarate treated cells (b), in $10^{-7} \mathrm{M}$ ATRA treated cells (c), in $10^{-8} \mathrm{MATRA}+10^{-6} \mathrm{M}$ liarozole-fumarate treated cells (d). - Bar $20 \mu \mathrm{m}$.

EXPRESSION OF CYTOSKELETAL PROTE:LNS (CYTOKERATINS 8, 18, 19; VIMENTIN; B-ACTIN)

The cytoskeletal proteins cytokeratins, vimentin and B-actin responded differentially upon ATRA treatment. Cytokeratins 8,18 and 19 were absent in control conditions and became intensely expressed after $10^{-7} \mathrm{M}$ or $10^{6} \mathrm{M}$ ATRA treatment but only in a low percentage of the cells $( \pm 20 \%)$. As an example. Figure 3 represents the expression obtained for cytokeratin 18 in the different treatment conditions. Strikingly, the neuronal-like cell type was the major cell phenotype staining for cytokeratin. Concentrations of ATRA lower than $10^{.7} \mathrm{M}$ were not effective in inducing cytokeratin expression. Single liarozole-fumarate treatment at $10^{6} \mathrm{M}$ or $10^{-5} \mathrm{M}$ resulted in a $\mathrm{F9}$ phenotype which was identical to control condition. However, the combination of $10^{-6} \mathrm{M}$ or $10^{-5} \mathrm{M}$ liarozole-fumarate with ATRA at $10^{-8} \mathrm{M}$ and $10^{-7} \mathrm{M}$ potentiated the ATRA effect. As an example, the same number and appearance of cytokeratin immunopositive F9 cells was visible after the combined $10^{-8} \mathrm{M}$ ATRA and $10^{-6} \mathrm{M}$ liarozole-fumarate treatment as compared to treatment with $10^{-7} \mathrm{M}$ ATRA alone. In contrast to cytokeratins, both vimentin (Fig, 4) and B-actin were expressed under all conditions. Treatment with either ATRA alone or liarozole-fumarate in combination with ATRA -at any concentration tested- did not induce any changes in the expression of vimentin or B-actin. 
EXPRESSION OF CELL ADHESION MOLECULES (E-CADHERIN, N-CAM)

The cell adhesion molecule E-cadherin (Fig. 5) was expressed in all F9 cells at the cell-cell boundary in control condition. Liarozole-fumarate treatment $\left(10^{-6} \mathrm{M}\right.$ or $\left.10^{-5} \mathrm{M}\right)$ resulted in a F9 phenotype which was identical to that of the control condition. However, treatment with ATRA at $10^{-7} \mathrm{M}$ or $10^{-6} \mathrm{M}$ downregulated E-cadherin expression in all cells. The neuronallike cells, appearing by ATRA treatment, also showed E-cadherin expression (Fig. 5). Concentrations of ATRA below $10^{-7} \mathrm{M}$ were ineffective in changing E-cadherin expression. However, the combination of $10^{-6} \mathrm{M}$ or $10^{-5} \mathrm{M}$ liarozole-fumarate with ATRA at $10^{-8} \mathrm{M}$ and $10^{-7} \mathrm{M}$ potentiated the ATRA effect. As an example, $10^{-8} \mathrm{M}$ ATRA combined with $10^{-6} \mathrm{M}$ or $10^{-5} \mathrm{M}$ liarozole-fumarate downregulated E-cadherin expression to the same extent as $10^{-7} \mathrm{M}$ ATRA alone.

$\mathrm{N}$-CAM was expressed in all F9 cells at control conditions. Liarozole-fumarate treatment $\left(10^{-6} \mathrm{M}\right.$ or $\left.10^{-5} \mathrm{M}\right)$ resulted in a $\mathrm{F} 9$ phenotype which was identical to that of the control condition. Treatment with ATRA at concentrations ranging from $10^{-7} \mathrm{M}$ to $10^{-6} \mathrm{M}$ increased N-CAM immunostaining in a subpopulation of cells $(30 \%)$ without any specific phenotypical appearance. At the same time. N-CAM was downregulated in most other cells. There was no link between the appearance of the neuronal-like cell type and N-CAM expression. The
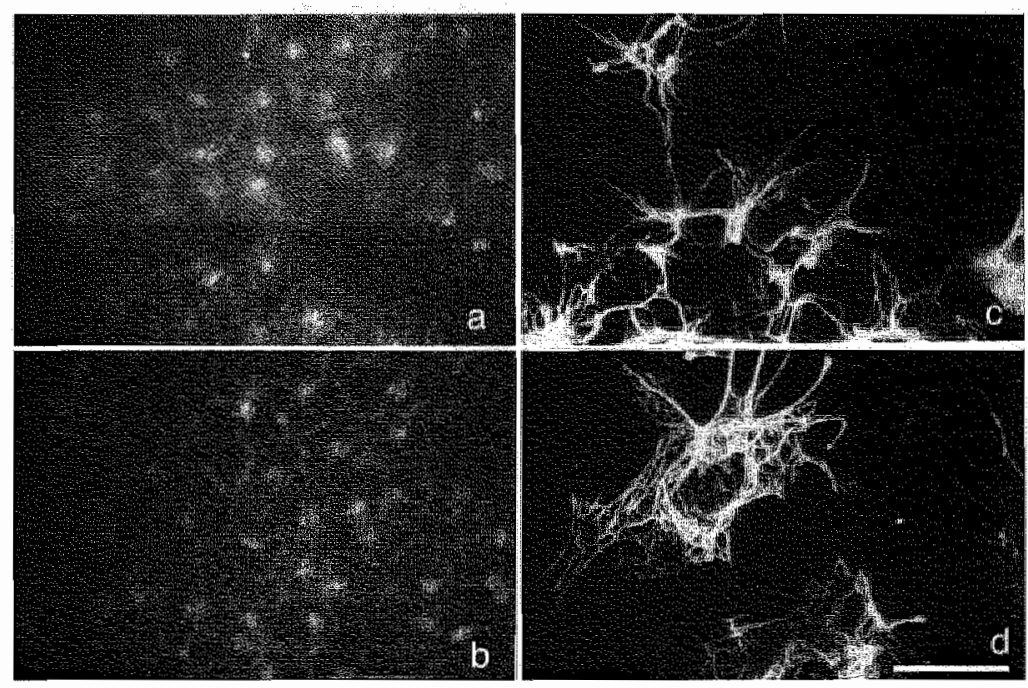

Figure 3: Expression of cytokeratin 18 in $F 9$ monolayer cell cultures in wehicle treated cells (a), in $10^{-6}$ M liarozole-fumarate treated cells (b), in $10^{-6} \mathrm{M}$ ATRA treated cells (c), in $10^{-7} \mathrm{M}$ ATRA + $10^{-6} \mathrm{M}$ liarozolefumarate treated cells (d). - Bar $10 \mathrm{\mu m}$. 
combination of $10^{-6} \mathrm{M}$ or $10^{-5} \mathrm{M}$ liarozole-fumarate with ATRA at $10^{-8} \mathrm{M}$ and $10^{-7} \mathrm{M}$ potentiated the ATRA effect. As an example, $10^{-8} \mathrm{M}$ ATRA combined with $10^{-6} \mathrm{M}$ or $10^{-5} \mathrm{M}$ liarozolefumarate increased N-CAM immunostaining to the same extent as $10^{-7} \mathrm{M}$ ATRA alone.

COMPARISON OF POTENTTATION OF LIAROZOLE-FUMARATE AT $10^{6} \mathrm{M}$ AND $10^{-5} \mathrm{M}$

For all the previously described markers, the number of immunopositive cells was the same after the combined treatment of ATRA with liarozole-fumarate at $10^{-6} \mathrm{M}$ or $10^{5} \mathrm{M}$. Thus, no differences in potentiation by the two liarozole-fumarate concentrations of the ATRA-induced differentiation were observed.

Liarozole-fumarate inhibits ATRA catabolism in F9 cells Using $10^{\circ 7} \mathrm{M}\left[{ }^{3} \mathrm{H}\right] \mathrm{ATRA}$ as the substrate, liarozole-fumarate was shown to inhibit ATRA catabolism with an $\mathrm{IC}_{50}$ of $3 \mu \mathrm{M}$ (Fig, 6). This $\mathrm{IC}_{50}$ value was 10 times higher than the $\mathrm{IC}_{50}$ value previously measured in MCF-7 cells $(0.3 \mu \mathrm{M})$ (Krekels $\mathrm{et}$ al. 1997).

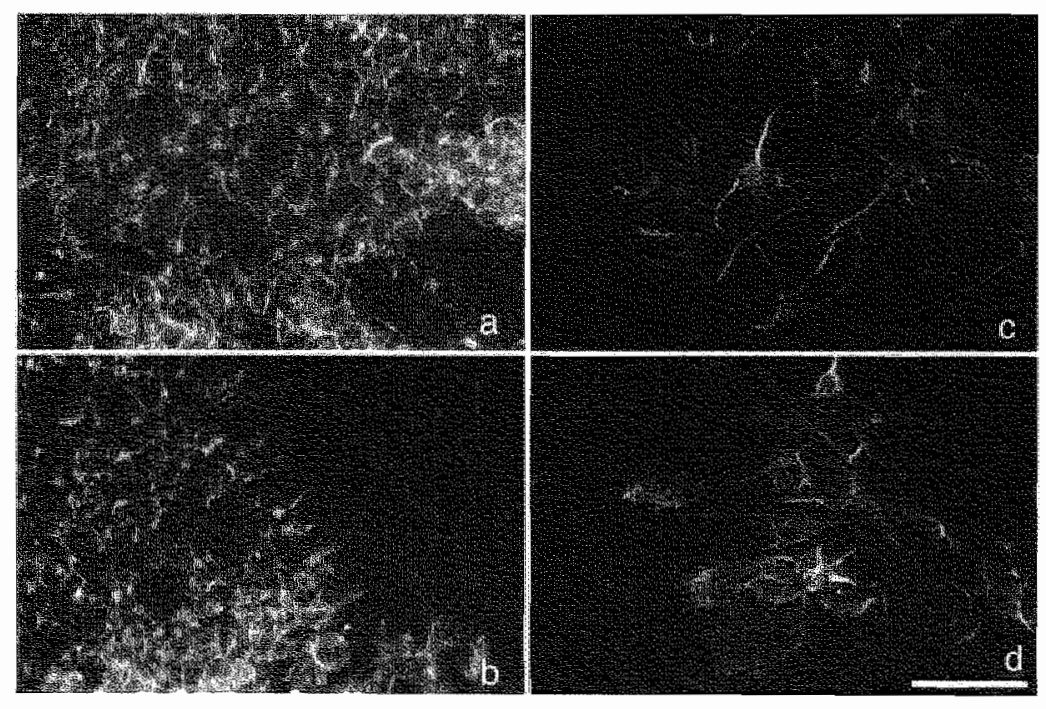

Figure 4: Expression of vimentin in F9 monolayer cell cultures in vehicle treated cells (a), in $10^{-6} \mathrm{M}$ liarozole-fumarate treated cells (b), in $10^{-6}$ $M$ ATRA treated cells (c), in $10^{-7}$ MATRA + $10^{-6}$ M liarozole-fumarate treated cells (d). - Bar $20 \mu \mathrm{m}$. 

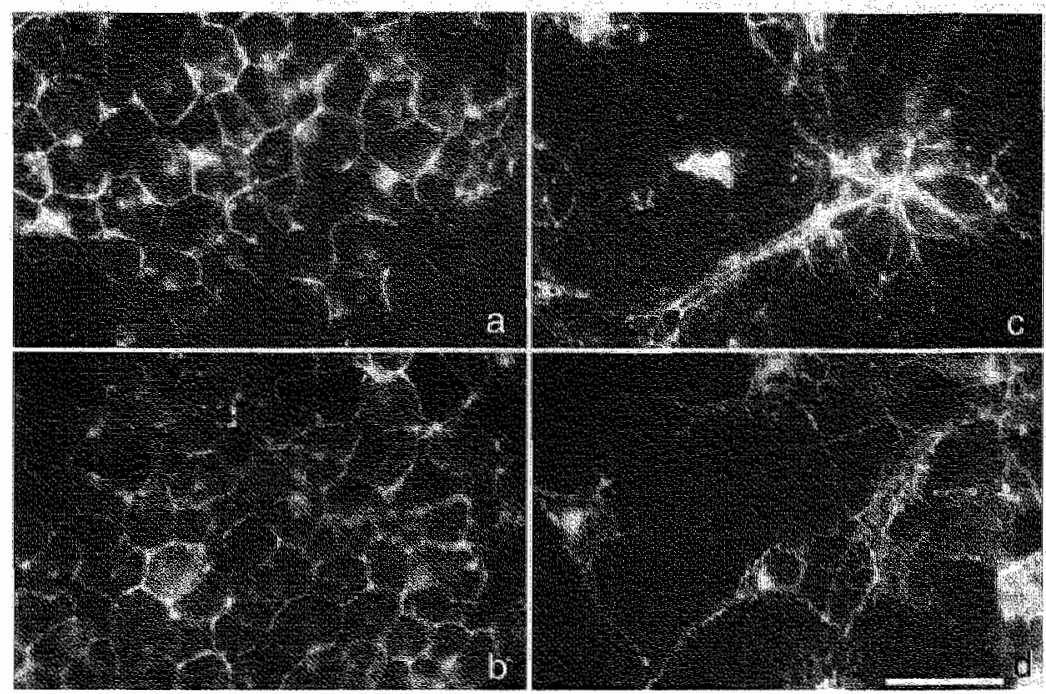

Figure 5: Expression of E-cadherin in F9 monalayer cell cultures in vehicle treated cells (a), in $10^{-6} \mathrm{M}$ liarozole-fumarate treated cells (b). in $10^{-6} \mathrm{M}$ ATRA treated cells $(\mathrm{c})$, in $10^{-7} \mathrm{MATRA}+10^{-6} \mathrm{M}$ liarozolefumarate treated cells (d). - Bar $10 \mu \mathrm{m}$.

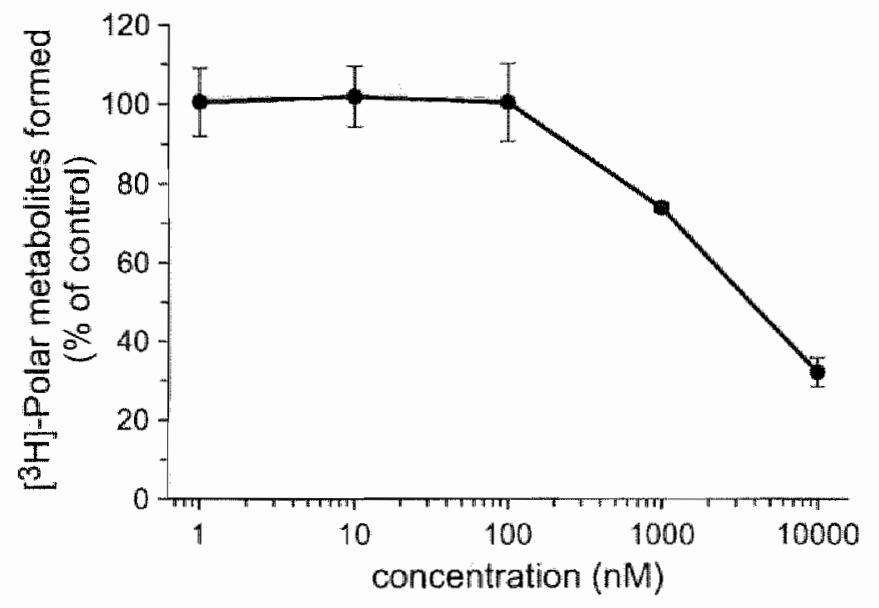

Figure 6: Inhibition of ATRA catabolism by liarozole-fumarate. 


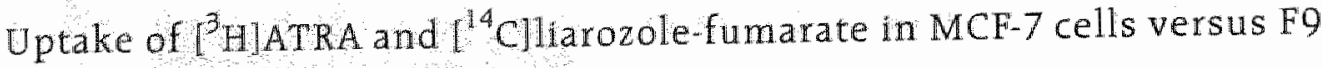
cells

The uptake of both ATRA and liarozole-fumarate was quantified in the two different cell lines and the respective ratio calculated, For $\left[^{3} \mathrm{H}\right] \mathrm{ATRA}$ at $10^{-8} \mathrm{M}$ and $10^{7} \mathrm{M}$, the mean ratio of uptake in MCF 7 versus uptake in F9 was $3.4 \pm 1.6$. For $I^{14} \mathrm{Clliarozole-fumarate}$ at $10^{-6} \mathrm{M}$ and $10^{-5} \mathrm{M}$, the mean ratio of uptake in $\mathrm{MCF}-7$ versus uptake in $\mathrm{F} 9$ was $6.9 \pm 2.1$. The respective ratios at each of the two concentrations of the respective compounds are given in Table II. Considerably lower uptake of both ATRA and liarozole-fumarate was thus seen in F9 cells as compared to MCF-7 cells.

Table II: Ratio for uptake of ATRA and of liarozole-fumarate in MCF-7 versus F9

\begin{tabular}{|c|c|}
\hline$\left.{ }^{3} \mathrm{H}\right]$ ATRA & uptake MCF-7/uptake F9 \\
\hline $10^{-8} \mathrm{M}$ & $5.0 \pm 1.9$ \\
$10^{-7} \mathrm{M}$ & $\begin{array}{c}3.9 \pm 1.5 \\
\text { mean }=3.4 \pm 1.6\end{array}$ \\
\hline$\left[{ }^{14} \mathrm{C}\right]$ liarozole-fumarate & uptake MCF-7/uptake F9 \\
\hline $10^{-6} \mathrm{M}$ & $5.6 \pm 1.5$ \\
$10^{-5} \mathrm{M}$ & $8.1 \pm 1.9$ \\
& mean $=6.9 \pm 2.1$ \\
\hline
\end{tabular}

\section{Discussion}

The present study confirms and extends the knowledge about the differentiation-inducing effects of ATRA in F9 monolayer cell cultures and, in addition, demonstrates the potentiation of this ATRA-induced differentiation process by liarozole-fumarate. ATRA at concentrations of $10^{-7} \mathrm{M}$ and $10^{6} \mathrm{M}$ was mostly effective in inducing differentiation. Moreover, the potentiation by liarozole-fumarate was due to inhibition of the ATRA catabolism (IC $_{50}$ of $3 \mu \mathrm{M})$.

ATRA-induced differentiation in Fo has been extensively described with ATRA at $10^{-6} \mathrm{M}$, but not yet in a concentration-responsive way. The present study demonstrated that only $10^{-7} \mathrm{M}$ 
and $10^{-6} \mathrm{M}$ ATRA-induced differentiation while lower concentrations were not active, except for the induction of laminin and collagen IV expression. These effects were noticed for both general phenotypic cellular appearance and for specific markers such as cytokeratins. E-cadherin and N-CAM. ATRA concentrations ranging from $10^{-7} \mathrm{M}$ to $10^{-6} \mathrm{M}$ induced two phenotypes: although all cells apparently flattened and got larger, about $20 \%$ of the cells differentiated into a neuronal-like cell type with long slender multiple branched outgrowths comparable to axons. Whereas most authors assume that ATRA treatment converts the epithelioid-like colonies of rounded undifferentiated F9 cells into triangular and flattened fibroblasts (for an overview: Burdsal et al. 1994), some authors described such an induction of a neuronal-like phenotype, but appearing in all cells of a F9 monolayer (Linder et al. 1981). Whether or not these discrepancies are related to the passage number of F9 cells cultures remains to be established.

Between $10^{-8} \mathrm{M}$ and $10^{-6} \mathrm{M}$. ATRA enhanced the expression of laminin and collagen IV. These data confirm the previously described upregulation of these extracellular matrix proteins in F9 monolayers upon ATRA treatment (Strickland and Mahdavi. 1978; Vasios et al., 1991; Maillet and Shur. 1994). Potentiation of these ATRA-linked effects was seen after liarozole-fumarate treatment: the combination of $10^{-9} \mathrm{M}$ ATRA with liarozole-fumarate enhanced the expression of both markers to the same extent as treatment with $10^{-8} \mathrm{M}$ ATRA alone. In contrast to the other markers, the expression of laminin and collagen IV was still upregulated by $10^{-8} \mathrm{M}$ ATRA and potentiated at $10^{-9} \mathrm{M}$ ATRA in combination with liarozolefumarate treatment. Apparently, laminin and collagen IV are more sensitive to ATRA differentiation than the other investigated markers, the latter being induced only at $10^{-7} \mathrm{M}$ and at $10^{-6} \mathrm{M}$. The induction of laminin and collagen IV expression appears to be directly regulated through ligated RAR binding on the corresponding RARE of their gene promotors. E.g. laminin B1 gene transcription occurred in F9 cells in function of ATRA treatment (Vasios et al. 1991). Chronologically. first RAR 3 was expressed $3 \mathrm{~h}$ after ATRA addition followed by the transcription of the laminin $B 1$ gene. The induction of laminin $B 1$ appeared to be mediated by direct binding of ligated RAR to three direct repeat TGACC-related motifs (RARE). There are several reports on the induction of cytokeratin expression in F9 cells treated with ATRA at $1 \mu \mathrm{M}$ (Ramaekers et al., 1984: Trevor et al. 1985. 1987. 1992; Kurki et al.. 1989; Pankov et al. 1994). The present study confirms these previous reports and illustrates the 10-fold potentiating effect of liarozole-fumarate on cytokeratin expression. Liarozolefumarate potentiated the differentiation effect of ATRA at $10^{-8} \mathrm{M}$ and induced a $\mathrm{F} 9$ phenotype comparable to that obtained with ATRA alone at $10^{-7} \mathrm{M}$. Strikingly, the cells with the neuronal phenotype were the only ones which showed expression of cytokeratin upon ATRA treatment. 
Their concomitant expression of vimentin is characteristic for an as yet rather low-grade neuronal differentiation.

On the other hand, the differentiation of a small fraction of FO cells towards a phenotype with such neuronal-like characteristics might explain why the expression of E-cadherin declined upon ATRA treatment with a concomitant upregulation of N-CAM. The absence of N-CAM from the neuronal-like cell type appearing after ATRA treatment is an as yet unexplained phenomenon. The cadherins and CAM's are spatiotemporally regulated during development and associated with a variety of morphogenetic events (Takeichi. 1988). E.g., during chicken embryogenesis, the ectoderm of the neural tube originally expresses Ecadherin in the entire region, but the part of the ectoderm that differentiates into the neuronal tube only gradually tums off expression of $\mathrm{E}$-cadherin, to be replaced by $\mathrm{N}$-cadherin. Uptake of both ATRA and liarozole-fumarate was about 5-fold lower in F9 than in MCF-7. These differences in uptake at least partially explain the 10 times higher $\mathrm{IC}_{50}$ value for inhibition of the retinoic acid catabolism by liarozole-fumarate in $\mathrm{F} 9\left(\mathrm{IC}_{50}=3 \mu \mathrm{M}\right)$ as compared to MCF- $7\left(\mathrm{IC}_{50}=0.3 \mu \mathrm{M}\right.$. Krekels et al. 1997). There was no difference in the number of immunopositive cells between the two tested liarozole-fumarate concentrations of $10^{-6} \mathrm{M}$ (close to $\mathbb{I C}_{50}$ ) and $10^{-5} \mathrm{M}\left(>\mathbb{I C}_{50}\right)$. The intensity of immunostaining is not sufficiently analytical, however, to evaluate whether eventually a higher amount of protein within the immunopositive cells was present at $10^{-5} \mathrm{M}$ liarozole-fumarate as compared to $10^{-6} \mathrm{M}$.

Not unexpectedly " the shifts in the expression of the same markers by ATRA and their concomitant potentiation by liarozole-fumarate were not comparable in $\mathrm{F} 9$ and MCF-7. F9 is an embryonic cell line differentiating towards predominant fibroblastoid endoderm. whereas MCF-7 is a typical epithelia] tumor cell line with other phenotypical characteristics.

In conclusion. ATRA concentration dependently modulated expression in F9 of laminin. collagen IV, cytokeratins 8.18, 19, vimentin, actin, E-cadherin and N-CAM. Liarozole-fumarate potentiated the ATRA effects by inhibition of catabolism. 


\section{References}

Atencia, R., Garcia-Sanz, M., Unda, F, and Aréchaga, I. Apoptosis during retinoic acid-induced differentiation of $F 9$ embryonal carcinoma cells. Exp. Cell Res. 21: 663-667, 1994.

Burdsa1, C. A., Lotz, M.M., Miller. J., and Mcclay, D.R. Quantitative switch in integrin expression accompanies differentiation of F9 cells treated with retinoic acid. Developmental Dynamics 201: 344-353, 1994 .

De Coster, R. Wouters, W., Van Ginckel, R., End, D. Krekels, M., Coene, M.-C., and Bowden, C. Experimental studies with liarozole (R T5251): an antitumoral agent which inhibits retinoic acid breakdown. J. Steroid Biochem. Mol. Biol. 43: 197-201. 1992.

Dijkman, G.A., Van Moortselaar, R.J.A., Van Ginckel, R., Van Stratum, P., Wouters, L., Debruyne, E.M.J., Schalken. J.A. and De Coster, R. Antitumoral effects of liarozole in androgendependent and -independent R3327-Dunning prostate adenocarcinomas. J. Urol. 151:217-222, 1994.

Hogan, B.L.M., Barlow, D.P., and Tilly, R. F9 teratocarcinoma cells as a model for the differentiation of parietal and visceral endoderm in the mouse embryo. Cancer Surveys 2: 115-140, 1983.

Hogan, B.L.M. Taylor, A., and Adamson, E. Cell interactions modulate embryonal carcinoma cell differentiation into parietal or visceral endoderm. Nature (London) 291: 235-237, 1981.

Krekels, M.D.W.G., Verhoeven, A., van Dun, J, Cools, W., Van Hove, C., Dillen, L. Coene, M.-C., and Wouters. W. Induction of the oxidative catabolism of retinoic acid in MCF-7 cells. Br. J. Cancer 75: 1098-1104,1997.

Kurki, P., Laasonen, A., Tan, E.M., and Lehtonen, E. Cell proliferation and expression of cytokeratin filaments in F9 embryonal carcinoma cells. Development 106: 635-640, 1989.

Linder, S., Krondahl, U., Sennerstam, R., and Ringertz. N.R. Retinolc acid-induced differentiation of F9 embryonal carcinoma cells. Exp. Cell Res. 132:453-460, 1981.

Mahler, C., Verhelst. J., and Denis, L. Ketoconazole and liarozole in the treatment of advanced prostatic cancer. Cancer 71: 1068-1073. 1993.

Maillet, C. and Shur, B.D. Perturbing cell surface B-(1,4)-galactosyltransferase on fro embryonal carcinoma cells arrests cell growth and induces laminin synthesis. J. Cell Science 107:1713$1724,1994$.

Martin, G.R., and Evans. M.J. Differentiation of donal lines of teratocarcinoma cells: formation of: embryoid bodies in vitro. Proc. Natl. Acad. Sci. U.S.A. 72: 1441-1445, 1975.

Pankov R., Neznanov, N.. Umezawa, A.. and Oshima R.G. AP.1. ETS, and transcriptional silencers regulate retinoic acid-dependent induction of keratin 18 in embryonic cells. Mol. Cell. Biol. 14 : 7744.7757. 1994. 


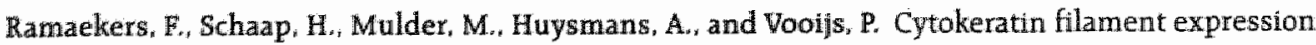
during in virro teratocarcinoma cell differentiation as detected by a monoclonal antibody. Cell Biology International Reports 8: 507-518, 1984.

Smets, G., Van Ginckel, R., Daneels, G., Moeremans, M, Van Wauwe, J., Coene, M.-C., Ramaekers, F.C.S. Schalken, J.A., Borgers, M., and De Coster. R. Liarozole, an antitumor drug. modulates cytokeratin expression in the Dunning AT-6sq prostatic carcinoma through in situ accumulation of all-trans-retinoic acid. Prostate 27: 129-140, 1995.

Strickland, S., Reich, E., and Sherman, M.I. Plasminogen activator in early embryogenesis: enzyme production by trophoblast and parietal endoderm. Cell 9: 231-240, 1976.

Strickland, S., and Mahdavi, V. The induction of differentiation in teratocarcinoma stem cells by retinolc acid. Cell 15:393-403, 1978.

Takeichi。 M. The cadherins: cell-cell adhesion molecules controlling animal morphogenesis. Development 102: 639-655. 1988.

Takeichi, M. Cadherin cell adhesion receptors as a morphogenetic regulator. Science 251: 1451-1455. 1991.

Trevor, K., and Oshima, R.G. Preimplantation mouse embryos and liver express the same type I keratin gene product. I. Biol. Chem. 260: 15885-15891, 1985.

Trevor, K., Linney, E., and Oshima, R.G. Suppression of endo B cytokeratin by its antisense RNA inhibits the normal coexpression of endo A cytokeratin. Proc. Natl. Acad. Sci. U.S.A. 84: 10401044. 1987.

Trevor, K.T. and Steben, L.S. Distribution of desmosomal proteins in F9 embryonal carcinoma cells and epithelial cell derivatives. J. Cell Science 103:69-80, 1992.

Van Ginckel, R., De Coster, R., Wouters, W., Vanherck, W., van der Veer, R., Goeminne, N., Jagers, E. Van Cauteren, H., Wouters, L., Distelmans, $W_{\text {.n }}$ and Janssen. P.A.J. Antitumoral effects of $R 75251$ on the growth of transplantable R3327 prostatic adenocarcinoma in rats. Prostate 16:313-323. 1990 .

Van heusden, J., Borgers, M., Ramaekers, F., Xhonneux, B., Wouters, W., De Coster, R., and Smets, G. Liarozole potentiates the all-trans-retinoic acid-induced structurall remodelling in human breast carcinoma MCF.7 cells in vitro. Eur. J. Cell Biol. 71: 89-98, 1996.

Van Wauwe, J.P., Coene, M.-C., Goosens. J.. Cools, W. and Monbaliu, J. Effects of cytochrome P450 inhibitors on the inv vivo metabolism of all-trans-retinoic acid in rats. J. Pharmacol. Exp. Ther. 252: 365-369, 1990 .

Van Wauwe. J., Van Nyen, G., Coene, M.-C., Stopple, P., Cools, W., Goossens. J., Borghgraef, P., and Janssen, P.A.I. Liarozole. an inhibitor of retinoic acid metabolism exerts retinoid-mimetic effects in vivo. J. Pharmacol. Exp. Ther. 261; 773-779, 1992. 
Van Wauwe, J., Coene, M.-C., Cools, W., Goosens, J., Lauwers, We Jeune, L., Van Hove, C., and Van Nyem, G. Liarozole-fumarate inhibits the metabolism of 4-keto-all-trans-retinolc acid. Biochem. Pharmacol. 47: 737-741, 1994.

Vasios, G., Mader, S., Gold, J.D.. Leid, M. Lutz, Y., Gaub, M.-P., Chambon, P., and Gudas, L. The late retinoic acid induction of laminin BI gene transcription involves RAR binding to the responsive element. EMBO J. 10:1149-1158, 1991.

Wouters, W., van Dun, J., Dillen, A., Coene, M.-C. Cools, W., and De Coster, R. Effects of liarozole, a new antitumor compound, on retinoic acid-induced inhibition of cell growth and on retinoic acid metabolism in MCF-7 human breast cancer cells. Cancer Res. 52, 2841-2846, 1992. 


\section{.}

se 


\section{Fluorescein-labeled tyramide strongly enhances the detection of low bromodeoxyuridine incorporation levels}

J. Histochem. Cytochem. 45: 315-319, 1997.

Jimmy Van heusden ${ }^{1}$, Paul de Jong ${ }^{2}$, Frans C.S. Ramaekers ${ }^{1}$, Hélène Bruwiere ${ }^{3}$. Marcel Borgers ${ }^{1,4}$ and Gerda Smets ${ }^{3}$

"Department of Molecular Cell Biology \& Genetics, University of Maastricht, P.O. Box 616,6200 MD Maastricht. The Netherlands: ${ }^{2}$ DuPont NEN, Life Science Products, Dordrecht, The Netherlands: ${ }^{3}$ Departments of Oncology and ${ }^{4}$ Morphology, Janssen Research Foundation. Tumhoutseweg 30, B-2340 Beerse, Belgium

\section{Abstract}

Immunocytochemical detection of bromodeoxyuridine (BrdU) labeling can be hampered by low BrdU incorporation levels. We describe here an amplification method for weak BrdU immunosignals.

The tyramide signal amplification method, based on catalyzed reporter deposition (CARD) uses fluorescein-labeled tyramide as a substrate for horseradish peroxidase. The enzyme catalyzes the formation of highly reactive tyramide radicals with a very short half-life, resulting in the binding 
of fluorescein-conjugated tyramide only at the site of the enzymatic reaction. MCF-7 cells were grown in vitro in medium containing charcoal-stripped fetal bovine serum supplemented by growth factors. Under these culture conditions, the BrdU immunosignal was hard to detect, but could be enhanced specifically by the tyramide signal amplification system, resulting in clear-cut differences between BrdU-negative and BrdU-positive cells. This enabled a rapid and objective quantification of the BrdU labeling index without the risk of underestimating the number of cells in S-phase. Therefore, this amplification of BrdU immunosignals might also prove valuable for in vivo cancer prognosis, cell kinetics studies, and computerassisted image analyses.

\section{Introduction}

Assessment of cell proliferation is considered a basic parameter in cancer studies. A range of techniques have evolved to quantify this process (Boulton and Hodgson, 1995). Bromodeoxyuridine ( $\mathrm{BrdU}$ ) labeling is an accurate method to measure cell proliferation because it is a direct assay of DNA synthesis (Dolbeare, 1995a, 1995b). BrdU is a halogenated derivative of thymidine that is incorporated into DNA only during S-phase of the cell cycle. It can be detected specifically by monoclonal antibodies with immunocytochemical techniques (Gratzner, 1982). Pulse labeling and a subsequent chase of BrdU allows the determination of dynamic proliferation parameters (Tinnemans et al., 1993).

However, the immunocytochemical detection of Brdu labeling can be hampered by low BrdU incorporation levels. Low incorporation levels of labeled nucleotides can occur as a consequence of altered cell growth rate (Aakvaaget al., 1990), which can be the result of the culture conditions used, such as the use of charcoal-stripped serum instead of untreated serum (Roman et al., 1993). This would result in weakly immunostained nuclei. In such cases. amplification of the $\mathrm{BrdU}$ signal is necessary to eliminate the considerable risk of underestimating the number of cells in S-phase and to ensure an objective quantification of the BrdU labeling index.

Catalyzed reporter deposition (CARD) is a signal amplification method that has been described by Bobrow et al. (1989, 1991). The amplification is achieved by biotin- or fluorescein-labeled tyramides that act as substrates for horseradish peroxidase. The horseradish peroxidase catalyzes the formation of highly reactive tyramide radicals that bind covalently to tyrosine 
residues (Bobrow et al. 1989, 1991). Because of the extremely short half-life of the tyranide radicals, only tyrosine residues in the direct surroundings of the horseradish peroxidase will bind tyramide (Bobrow et al. 1989. 1991). The biotin-labeled tyramide can then be visualized by fluorochrome- or enzyme-labeled streptavidin.

Although originally developed for ELISA, this technique has been adapted for immunohistochemistry on tissue sections (Adams. 1992. Berghorn et al., 1994; Merz et al. 1995) and for in situ hybridization (Kerstens et al. 1995; Raap et al., 1995).

In this study. MCF-7 human breast cancer cells were used. grown in vitro in medium containing charcoal-stripped fetal bovine serum supplemented by growth factors. Under these culture conditions. these cells are known to have an increased cell doubling time (Berthois et al., 1986: Aakvaag et al., 1990; Roman et al., 1993), resulting in low BrdU incorporation levels and thus weak BrdU immunosignals. Fluorescein-labeled tyramide (Bobrow et al., 1991) was used as a substrate for horseradish peroxidase to amplify specifically the weak immunocytochemical signal of BrdU labeling. The tyramide signal amplification method enabled a rapid and objective quantification of the Brdu labeling index without the risk of underestimating the number of cells in S-phase.

\section{Materials and Methods}

\section{Materials}

Dulbecco's modified Eagle"s medium (DMEM) with $4.5 \mathrm{~g} / 1 \mathrm{iter}$ glucose, phenol red-free DMEM with 1 g/iter glucose, and $1 \mathrm{mM}$ sodium pyruvate, fetal bovine serum (FBS), L-glutamine, gentamicin, bovine insulin, basic fibroblast growth factor, sodium selenite, and transferrin were purchased from Life Technologies (Ghent. Belgium).

Dextran T500 was obtained from Pharmacia (Uppsala, Sweden) and activated charcoal from Sigma (St. Louis. MO, U.S.A.). Charcoal-stripped FBS was prepared by treating FBS with dextran-coated charcoal (DCC-FBS), according to the protocol of Horwitz and McGuire (1978).

Monoclonal antibody to BrdU (clone BU-1) containing nuclease activity was purchased from Amersham (Poole. United Kindom). Secondary biotinylated goat anti-mouse IgG was obtained from DAKO A/S (Prosan: Ghent, Belgium) and secondary fluorescein isothiocyanate (FITC)-labeled goat anti-mouse IgG from Southern Biotechnology Associates (Birmingham, AL. U.S.A.). The Tyramide Signal Amplification (TSA)-Direct kit (Green) was obtained from DuPont NEN Products (Brussels. Belgium) and contained blocking reagent, horseradish peroxidase-conjugated streptavidin. $2 \mathrm{X}$ concentrated amplification diluent, and fluorescein-labeled tyramide. 


\section{Cell Culture}

Routinely, MCF-7 human mammary carcinoma cells, purchased from the American Type Culture Collection (Rockville. MD. U.S.A.), were cultured in DMEM with 4.5 g/liter glucose supplemented by $10 \% \mathrm{FBS}, 2 \mathrm{mM} \mathrm{L-glutamine,} 1 \mathrm{mM}$ sodium pyruvate, and $50 \mu \mathrm{g} / \mathrm{ml}$ gentamicin. The MCF-7 subclone used in this study has been described previously (Van heusden of al. 1996). Cells were grown in a humidified incubator ( $5 \% \mathrm{CO}_{2}, 95 \%$ air) at $37^{\circ} \mathrm{C}$ and were Mycoplasma-free.

For the growth experiments. cells were cultured for 6 days in phenol red-free DMEM containing $5 \%$ DCC.FBS, $4.5 \mathrm{~g} /$ liter glucose, $2 \mathrm{mM} \mathrm{L}$ glutamine, $1 \mathrm{mM}$ sodium pyruvate, $50 \mu \mathrm{g} / \mathrm{ml}$ gentamicin. $30 \mathrm{nM}$ sodium selenite, and $10 \mu \mathrm{g} / \mathrm{ml}$ transferrin. Then cells were seeded onto Chamber Slides ${ }^{\mathrm{ru}}$ (Nunc, Naperville, IL, U.S.A.), coated with $50 \mu \mathrm{g} / \mathrm{ml}$ poly-L-lysine (PLL) 1 day before use, at a concentration of 15,000 cells/chamber. Cells were a]lowed to attach for $24 \mathrm{~h}$ and thereafter growth factors were added $(10 \mu \mathrm{g} / \mathrm{ml}$ final concentration insulin and $5 \mathrm{ng} / \mathrm{ml}$ final concentration basic fibroblast growth factor). Cells were grown under these conditions for 7 days, with medium changes 3 and 6 days after seeding. Control cells, growing in medium containing 10\% untreated FBS, were seeded from stock cultures on to PLL-coated Chamber Slides ${ }^{\text {re }}$ at a concentration of 2500 cells/chamber. Cells were grown under these conditions for 7 days, with medium changes 3 and 6 days after seeding.

\section{BrdU labeling and immunodetection}

Cells grown for 7 days under the different culture conditions described above, were incubated for 2.5 $\mathrm{h}$ with an excess $(100 \mu \mathrm{M})$ of BrdU at $37^{\circ} \mathrm{C}$ in an incubator. Thereafter. cells were washed twice with serunt-free culture medium and fixed in methanol $\left(5 \mathrm{~min},-20^{\circ} \mathrm{C}\right)$ and acetone $\left(10 \mathrm{~s}_{4}-20^{\circ} \mathrm{C}\right)$, and airdried. Cells were then ready to use for Brdu detection, according to the following Protocols $A$ or $B$.

\section{Protocol A: Brdu Detection by CONVENTIONAL IMmunofluorescence STAINING}

1. Slides were blocked in $5 \%$ normal goat serum in $10 \mathrm{mM}$ phosphate buffered saline (PBS) (pH 7.4) for $1 \mathrm{~h}$ in a dark, moist chamber at room temperature (RT).

2. Slides were rinsed three times for 10 min with PBS at RT.

3. Slides were incubated with monoclonal antibody against BrdU containing nuclease (diluted $1: 5$ in PBS) for 5 h at RT in a dark, moist chamber. Omission of the primary antibody did not reveal any signal. Different incubation times ( $\mathrm{h}, 3 \mathrm{~h}, 4 \mathrm{~h}, 5 \mathrm{~h}$, and $16 \mathrm{~h}$ ) and antibody dilutions $(1: 2,1,5,1,8,1: 10)$ were tested. The best results were obtained with an incubation time of 5 h and an antibody dilution of $1: 5$.

4. Slicles were rinsed three times for $10 \mathrm{~min}$ with PBS at RT and stoned overnight.

5. Slides were incubated with FITC-labeled goat anti-mouse IgG (diluted 1:60 in PBS) for 1 h at RT in a dark, moist chamber.

6. Slides were rinsed three times for 10 min with PBS at RT.

7. Slides were postfixed for 10 min in methanol at RT.

8. Slides were posttixed for $10 \mathrm{~min}$ in $4 \%$ paraformaldehyde in PBS at RT.

9. Slides were rinsed three times for 10 min with PBS at RT. 
10. Slides were rinsed three times for $10 \mathrm{~min}$ with distilled water at RT.

11. Slides were air-dried and mounted in Mowiol contatning propidium lodide (PI, $2 \mu \mathrm{g} / \mathrm{m}$ l final concentration) and RNAse $(20 \mathrm{\mu g} / \mathrm{ml}$ final concentration $)$ to stain nuclei.

Protocol B: Brou DETECTION BY TYRAMIDE SIGNAL AMPLIFICATION

1. Endogenous peroxidase activity was blocked by incubating slices in $0.03 \% \mathrm{H}_{2} \mathrm{O}_{2}$ diluted in PBS for 30 min at room temperature (RT).

2. Slides were washed twice for 5 min in PBS at RT.

3. Slides were blocked in $5 \%$ normal goat serum in $10 \mathrm{mM}$ PBS (PH 7.4) for 1 hat RT in a dark, moist chamber.

4. Slides were rimsed three times for 10 min with PBS at RT.

5. Slides were incubated with monoclonal antibody against BrdU containing muclease (diluted 1:8 in PBS) for $5 \mathrm{~h}$ at RT in a dark, moist chamber. Omission of the primary antibody did not reveal any signal. Different incubation times $(1 \mathrm{~h}, 3 \mathrm{~h}, 4 \mathrm{~h}$, and $5 \mathrm{~h})$ and antibody dilutions $(1: 2,1: 5,1: 8,1: 10)$ were tested. The best results were obtained with an incubation time of $5 \mathrm{~h}$ and an antibody dilution of $1: 8$.

6. Slides were rinsed three times for 10 min with PBS at RT and stored overnight.

7. Slides were incubated with biotinylated goat anti-mouse IgG (diluted 1:300 in PBS) for 30 min at RT in a dark. moist chamber.

8. Slides were rinsed three times for 5 min with PBS at RT.

9. Slides were blocked with 0.5\% DuPont Blocking Reagent in 0.1 $\mathrm{M}$ Tris-HCl (pH 7.5) containing $0.15 \mathrm{M} \mathrm{NaCl}$ (TBS) for $30 \mathrm{~min}$ at RT in a dark, moist chamber.

10. Slides were incubated for $30 \mathrm{~min}$ with streptavidin-HRP diluted 1.500 in TBS containing $0.5 \%$ DuPont Blocking Reagent at RT in a dark, moist chamber .

11. Slides were rinsed three times for 5 min with TBS containing 0.05\% Tween 20 (TBST) by shaking at $\mathbb{R T}$.

12. Slides were incubated with fluorescein-labeled tyramide diluted $1: 50$ in $1 \mathrm{X}$ amplification buffer for 10 min at RT in a dark, moist chamber. Different incubation times (1 min. $5 \mathrm{~min}$, and 10 min) and dilutions (1:25 and 1:50) were tested. An incubation of 10 min and a dilution of 1:50 gave the best results.

13. Slides were rinsed three times for 5 min with TBST by shaking.

14. Slides were rinsed three times for $5 \mathrm{~min}$ with distilled water at RT.

15. Slides were postfixed in methanol for $5 \mathrm{~min}$ at RT.

16. Slides were air-dried and mounted in Mowiol containing PI ( $2 \mu \mathrm{g} / \mathrm{m}$ l final concentration) and RNAse $(20 \mu \mathrm{g} / \mathrm{ml}$ final concentration) to stain nuclei.

The Brdu labeling index i.e. the percentage of cells in S-phase of the cell cycle, was determined by counting cells under a fluorescence microscope (Axiophot: Zeiss, Oberkocher. Germany) with a dual filter set for simultaneous visualization of both fluorescein and PI. About 800 cells were counted twice for each test condition per experiment. Results are presented as mean $\pm \operatorname{SEM}(n=3)$. 


\section{Statistical analysis}

Data were analyzed with the twotalled Mann-Whitney U-test using Stat View II software (Abacus Concepts: Berkeley. CA. U.S.A.). Significance was defined at the level of $p<0.05$.

\section{Results}

Control MCF 7 cells, grown in medium containing untreated FBS. showed a BrdU labeling index (Table I) of 36.8 1 1.3\%. as described previously (Van heusden et al., 1996). On BrdU immunodetection. normal BrdU incorporation levels were observed, which resulted in strongly immunoreactive nuclei.

In contrast, cells grown in medium containing charcoal-stripped FBS supplemented with growth factors showed low BrdU incorporation levels. This was reflected by weak BrdU immunosignals, which were hard to detect, using the conventional immunofluorescence staining procedure (Eig. la). BrdU-positive nuclei were stained faintly and showed a heterogeneous punctate staining pattern (Fig. 1a. inset). The BrdU labeling index (Table I) was $27.9 \pm 0.6 \%$. which was statistically different $(p<0.05)$ from that of cells grown in medium containing untreated serum.

The tyramide signal amplification method strongly enhanced the BrdU immunosignal (Fig. lb) of cells grown in medium containing charcaal-stripped serum. The nuclei were now stained intensely and the majority of the cells were homogeneously BrdU-positive (Fig. $1 \mathrm{~b}$. inset), whereas some cells partially retained their original punctate staining (Fig. 1b. inset).

Table I: BrdU labeling index for MCF-7 cells

\begin{tabular}{lcc}
\hline & \multicolumn{2}{c}{ BrdU labeling index } \\
\cline { 2 - 3 } culture conditions & $\begin{array}{c}\text { conventional } \\
\text { immunofluorescence }\end{array}$ & TSA \\
\hline $10 \%$ untreated FBS & $36.8 \pm 1.3 \%$ & ND $^{\text {b }}$ \\
$5 \%$ DCC.FBS + growth factors & $27.9 \pm 0.6 \%{ }^{c}$ & $26.9 \pm 0.9 \%$ \\
\hline
\end{tabular}

\footnotetext{
Mean $\pm \operatorname{SEM}(n=3)$

${ }^{\mathrm{b}} \mathbb{N D}=$ not done.

'Hardly detectable.
} 

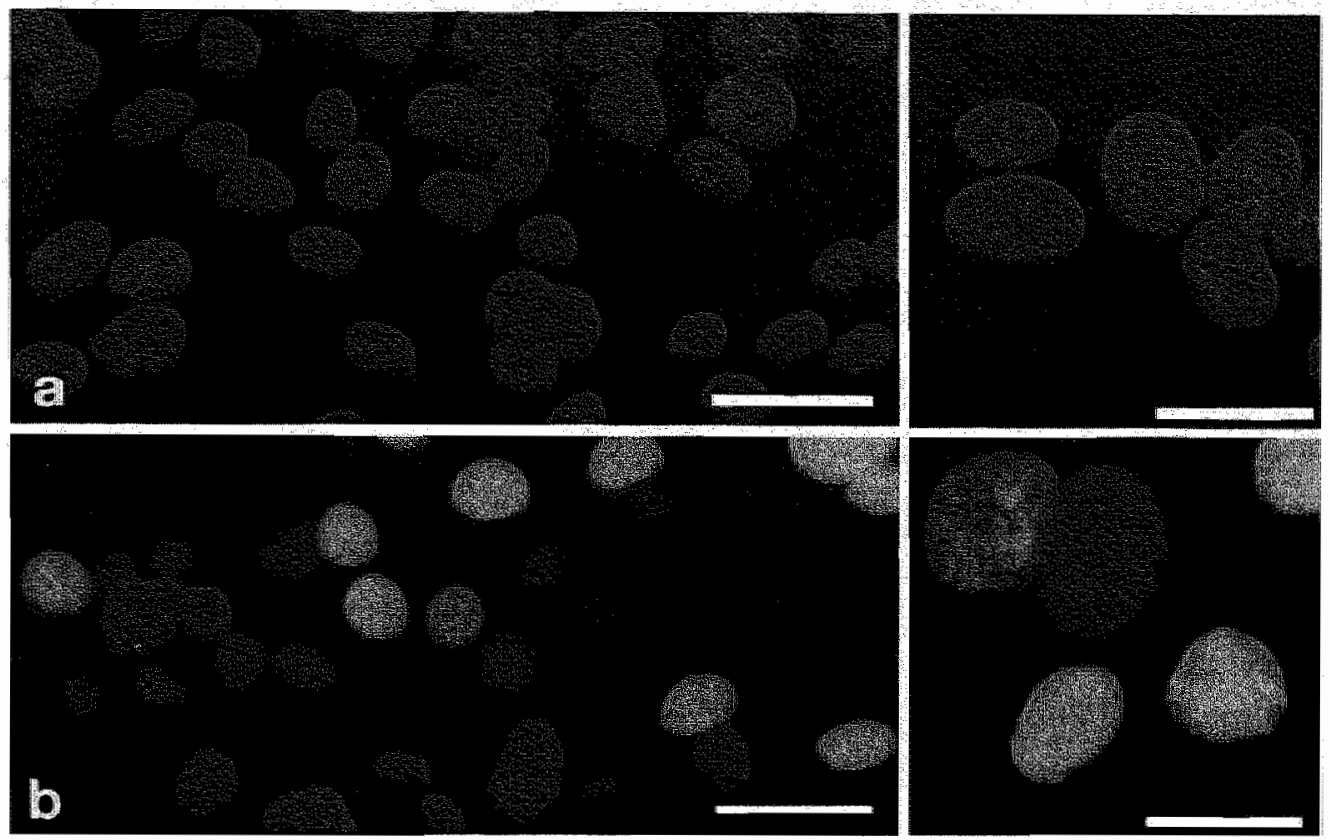

Figure I: BrdU immunodetection in MCF-7 human breast cancer cells grown in medium containing $5 \%$ charcoal-stripped fetal bovine serum supplemented with growth factors. Visualization was achieved by (a) conventional immunofluorescence staining or (b) tyramide signal amplification. - Bars $20 \mu \mathrm{m}$, insets $10 \mu \mathrm{m}$.

On immunofluorescence microscopy, no significant fading of the fluorescein signal was observed in contrast to the conventional immunofluorescence staining preparations, most probably owing to the intense amplification of the immunosignal.

After visualization with the tyramide signal amplification method, a Brdu labeling index (Table I) of $26.9 \pm 0.9 \%$ was obtained which was not statistically different $(p=0.14$ ) from the labeling index (Table I) of $27.9 \pm 0.6 \%$ that was obtained with normal immunofluorescence staining. This means that no additional cells became labeled after the tyramide signal amplification. 


\section{Discussion}

MCF. 7 cells. grown in medium containing charcoal-stripped FBS supplemented by growth factors, showed a decreased Brdu labeling index compared to that of cells grown in medium containing untreated fetal bowine serum. This was not surprising because it is known that MCF-7 cells are estrogen-dependent (Brooks et al. 1973, Aakvaag et al, 1990) and the MCF-7 cells used in this study were cultured essentially in the complete absence of estrogens by the use of phenol red-free medium and charcoal-stripped serum (Horwitz and McGuire. 1978: Berthois et al. 1986), Furthermore. MCE-7 cells grown in medium containing charcoalstripped serum and insulin showed an increased cell doubling time and lowered thymidine incorporation in the absence of 17B-estradiol (Aakvaag et al., 1990).

As a consequence of these culture conditions low BrdU incorporation levels were observed, most probably due to an increased cell doubling time (Berthois et al., 1986; Aakvaag et al.. 1990; Roman et al., 1993). This resulted in weak BrdU immunosignals that made quantification of the BrdU labeling index very labor-intensive and time-consuming and, more importantly, a considerable risk remained for underestimating the number of cells in S-phase.

Therefore, an immunofluorescence amplification procedure using fluorescein-labeled tyramide, based on the principle of CARD, was developed for cell cultures to enhance specifically the BrdU immunosignals. In contrast to the weak. heterogeneous BrdU staining using the conventional immunofluorescence protocol, the tyramide signal amplification method resulted in a much clearer and homogeneous BrdU immunosignal in the majority of the cells. The difference between BrdU-positive and BrdU-negative cells became clearcut. which made quantification rapid "easy, and objective without the risk of underestimating the number of cells in S-phase. Some cells stained intensely but partially retained their punctate staining pattern, which is indicative of the specificity of the tyramide signal amplification in that it is restricted to the immediate surroundings of the HRP deposits. The Brdu labeling index determined after tyramide signal amplification was the same as that determined after conventional immunofluorescence staining. This suggests that the tyramide signal amplification method is specific and that no additional cells became positive. The tyramide signal amplification for low BrdU levels might also lend itself to providing more accurate results for prognosis after in vivo BrdU administration.

Another application of the tyramide signal amplification might be in cell kinetics studies. For that purpose. it would be necessary to adapt the current fluorescent amplification procedure so that cells could be stained in suspension for flow cytometric analysis. 
Furthermore. the tyramide signal amplification method might help in the development of computer-assisted image analysis. For this application. it is necessary to obtain consistently clear and stable immunostaining, resulting in high-contrast images that facilitate the identification of labeled and unlabeled nuclei.

In conclusion, we have described an amplification method using CARD to amplify specifically weak BrdU immunosignalls due to low BrdU incorporation levels. Amplification was achieved by the use of fluorescein-labeled tyramide as a substrate for horseradish peroxidase. The tyramide signal amplification method holds the promise to be of great value for in vivo cancer prognosis, cell kinetics studies, flow cytometry, and computer-assisted image analysis.

\section{Acknowledgements}

We thank Lambert Leijssen and Hans Henderickx for the photographic layout.

\section{References}

Aakvaag. A. Utaaker, E, Thorsen, T., Lea, O,A., and Lahooti, H. Growth control of human mammary cancer cells (MCF-7 cells) in culture: effect of estradiol and growth factors in serum-containing medium. Cancer Res. 50:7806-7810, 1990.

Adams, J.C. Biotin amplification of biotin and horseradish peroxidase signals in histochemical stains. J. Histochem. Cytochem. 40: 1457-1463, 1992.

Berghorn, K.A., Bonnett, J.H., and Hoffman. G.E. CFos immunoreactivity is enhanced with biotin amplification. J. Histochem. Cytochem. 42: 1635-1642, 1994.

Berthois, Y., Katzenellenbogen. J.A., and Katzenellenbogen, B.S. Phenol red in tissue culture media is a weak estrogen: implications concerning the study of estrogen-responsive cells in culture. Proc. Natl. Acad. Sci. U.S.A. 83: 2496-2500, 1986.

Bobrow, M.N., Harris, T.D., Shaughmessy. K.J. and Litt, G.J. Catalyzed reporter deposition, a novel method of signal amplification. Application to immunoassays. J. Immunol. Methods $125: 279-$ 285. 1989 .

Bobrow, M.N., Shaughnessy. K.J., and Litt. G.J. Catalyzed reporter deposition, a novel method of signal amplification. II. Application to membrane immunoassays. J. Immunol. Methods 137; 103-112, 1991. 
Boulton, R.A., and Hodgson, H.J.F. Assessing cell proliferation: a methodological review. Clin. Sci. 88: $119.130,1995$.

Brooks, S.C., Locke, E.R., and Soule. H.D. Estrogen receptor in a human cell line (MCF-7) from breast carcinoma. J. Biol Chem. 248: 6251-6253, 1973.

Dolbeare, F. Bromodeoxyuridine: a diagnostic tool in biology and medicine, part I: Historical perspectives, histochemical methods and cell kinetics. Histochem. J. 27:339-369. 1995a.

Dolbeare, F. Bromodeoxyuridine: a diagmostic tool in biology and medicine, part II: Oncology. chemotherapy and carcinogenesis. Histochem. J. 27:923-964, 19956.

Gratzner, H.G. Monoclonal antibody to 5-bromo- and 5-iododeoxyuridine: a new reagent for detection of DNA replication. Science 218: 474 475, 1982.

Horwitz, K.B., and McGuire, W.L. Estrogen control of progesterone receptor in human breast cancer. J. Biol. Chem. 253: 2223:-2228, 1978.

Kerstens, H.M.J., Poddighe, P.J., and Hanselaar, A.G.J.M. A novel in situ hybridization signal amplification method based on the deposition of blotinylated tyramine. 1. Histochem. Cytochem. 43: 347-352, 1995.

Merz, H.. Malisius, R.. Mannweiler, S., Zhou, R. Hartmann, W., Orscheschek, K, Moubayed, P., and Feller, A.C. Immunomax. A maximized immunohistochemical method for the retrieval and enhancement of hidden antigens. Lab. Invest. 73: 149-156. 1995.

Raap, A.K, van de Corput, M.P.C., Vervenne, R.A.W.. van Gijlswijk, R.P.M., Tanke, H.J., and Wiegant. J. Ultra-sensitive FISH using peroxidase-mediated deposition of biotin- or fluorochrome tyramides. Hum. Mol. Genet. 4: 529-534, 1995.

Roman, S.D., Ormandy, C.J., Manning, D. L., Blamey, R.W." Nicholson, R.I., Sutherland, R.L., and Clarke. C.L. Estradiol induction of retinoic acid receptors in human breast cancer cells. Cancer Res. 53: 5940-5945. 1993.

Tinnemans, M.M.F.J., Schutte, B., Lenders, M.-H.J.H., ten Velde, G.P.M., Ramaekers, F.C.S., and Blijham G.H. Cytokinetic analysis of lung cancer by in vivo bromodeoxyuridine labeling. Br. J. Cancer 67: 1217-1222, 1993.

Van heusden, J., Borgers, M., Ramaekers, F., Xhonneux, B., Wouters, W., De Coster, R., and Smets, G. Liarozole potentiates the all-trans-retinoic acid-induced structural remodelling in human breast carcinoma MCF 7 cells in vitro. Eur. J. Cell Biol. 71: 89-98, 1996. 



\section{All-trans-retinoic acid metabolites significantly inhibit the proliferation of MCF-7 human breast cancer cells in vitro}

Br. J. Cancer, in press.

Jimmy Van heusden ${ }^{1}$. Walter Wouters ${ }^{2}$, Frans C.S. Ramaekers ${ }^{1}$. Marita D.W.G. Krekels $^{2}$, Lieve Dillen ${ }^{3}$, Marcel Borgers ${ }^{1.4}$ and Gerda Smets ${ }^{2}$

${ }^{1}$ Department of Molecular Cell Biology \& Genetics, University of Maastricht, P.O. Box 616, 6200 MD Maastricht, The Netherlands: ${ }^{2}$ Departments of Oncology. ${ }^{3}$ Immunology and "Morphology" Janssen Research Foundation. Turnhoutseweg 30. B-2340 Beerse. Belgium

\section{Abstract}

All-trans-retinoic acid (ATRA) is well known to inhibit the proliferation of human breast cancer cells. Much less is known about the antiproliferative activity of the naturally occurring metabolites of ATRA. In the present study. we investigated the antiproliferative activity of ATRA, its physiological catabolites 4-oxo-ATRA and 5,6-epoxy-ATRA and isomers 9-cis-RA and 13cis-RA in MCF-7 human breast cancer cells by bromodeoxyuridine incorporation.

MCF-7 cells were grown in steroid- and retinoid-free medium supplemented 
with growth factors. Under these culture conditions, ATRA and its naturally occurring catabolites and isomers showed significant antiproliferative activity in MCF-7 cells in a concentration-dependent manner $\left(10^{-11} \mathrm{M}\right.$ to $\left.10^{-6} \mathrm{M}\right)$. The antiproliferative activity of ATRA catabolites and isomers was equal to that of the parent compound ATRA at concentrations of $10^{-8} \mathrm{M}$ and $10^{-7} \mathrm{M}$. Only at $10^{-6} \mathrm{M}$, the catabolites and the stereoisomer 13-cis-RA were less potent. The stereoisomer 9-cis-RA was as potent as ATRA at all concentrations tested $\left(10^{-11} \mathrm{M}\right.$ to $\left.10^{-6} \mathrm{M}\right)$. In addition, we show that the catabolites and isomers were formed from ATRA to only a limited extent.

Together, our findings suggest that in spite of their high antiproliferative activity the catabolites and isomers of ATRA cannot be responsible for the observed growth inhibition induced by ATRA.

\section{Introduction}

Retinoic acid (RA) has been shown to exert antiproliferative and differentiation-inducing effects on cancer cells both in vitro and in vivo (Gudas et al., 1994: Moon et al., 1994). These effects are mediated through binding to nuclear retinoid receptors. namely the RA receptors (RARs) and the retinoid X receptors (RXRs). Both receptors are members of the nuclear receptor superfamily and function as ligand-dependent transcription factors (Chambon, 1996). The RAR family is activated both by ATRA and by 9-cis-RA, whereas the RXR family is activated exclusively by 9-cis-RA (Chambon, 1996). The ability of the natural stereoisomer 13-cis-RA to bind to RARs is controversial.

Diversity in the control of gene expression by RA exists because of the complexity at different levels of the signalling pathway. An important level in this complex retinoid signalling pathway is represented by the existence of natural metabolites of all-trans-RA (ATRA), whose synthesis may be modulated cell-specifically (Napoli, 1996). ATRA metabolism has been studied in a variety of tissues and a number of metabolites have been identified (Fig. 1). One important catabolic pathway for ATRA is initiated by hydroxylation at the 4-position of the B-ionone ring of ATRA to yield 4-hydroxy-ATRA (Frolik et al. 1979; Roberts et al. 1980). This step is catalyzed by a cytochrome P450-dependent ATRA 4-hydroxylase (Roberts et al.. 1980: White et al. 1996). 4-Hydroxy-ATRA is further oxidized via 4-oxo-ATRA to more polar metabolites (Roberts et al., 1980). This latter step involves at least one other, presently unknown, cytochrome P450-dependent enzyme (Roberts et al., 1980; Van Wauwe et al., 1994). Epoxidation of ATRA yields 5,6-epoxy-ATRA (McCormick et al., 1978). ATRA can also 


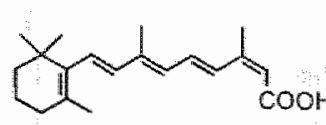

13-cis-retinoic acid

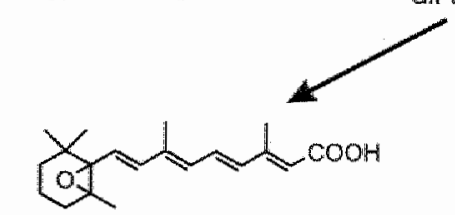

5,6-epoxy-all-trans-retinoic acid

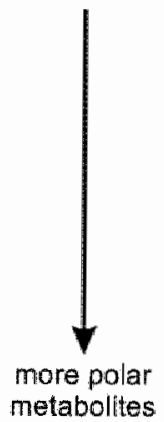

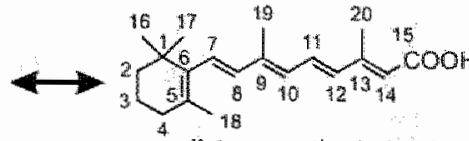

all-trans-retinoic acid

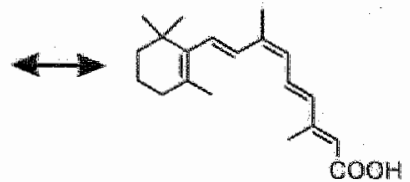

9-cis-retinoic acid
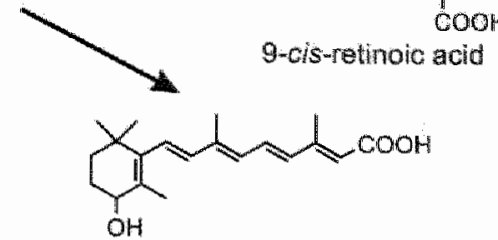

4-hydroxy-all-trans-retinoic acid

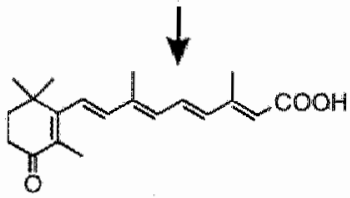

4-oxo-all-trans-retinoic acid

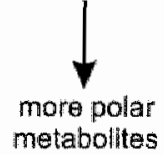

Figure 1: Chemical structures of ATRA, its naturally occurring isomers and catabolites arising from two different catabolic pathways.

isomerize to 9-cis-RA and 13-cis-RA, an obviously non-enzymatic process (Urbach and Rando. 1994).

Cancer cells have been shown to posses RA catabolic activity. Oxidative catabolism of RA to more polar metabolites was observed in $N$-methyl- $N$-nitrosourea-induced mammary tumors in the rat (Bhat and Lacroix, 1989), in rat Dunning $\mathrm{R} 3327 \mathrm{G}$ prostate tumors (Krekels et al. 1996). F9 mouse teratocarcinoma cells (Williams and Napoli, 1985). LLC-PK pig kidney cancer cells (Napoli. 1986). BA-HAN-1C rat rhabdomyosarcoma cells (Biesalski et al., 1990), as well as in the human breast cancer cells MCF-7 (Wouters et al., 1992; Krekels et al., 1997) and T47D (Han and Choi, 1996).

Recently. Takatsuka et al. (1996) showed a positive relationship between metabolism of ATRA in human breast cancer cells and the antiproliferative activity of ATRA, suggesting that an undefined metabolite of ATRA, rather than the parent compound itself, could be responsible for the observed growth inhibition induced by ATRA. Up to now only limited and conflicting results have been published concerning the activity of the naturally occurring 
ATRA metabolites in tumors. To clarify these points, we studied the antiproliferative activity of AIRA, its physiological catabolites 4-oxo-ATRA and 5.6-epoxy-ATRA and isomers 9-cis-RA and 13-cis-RA in MCF-7 cells using a bromodeoxyuridine incorporation assay. Bromodeoxyuridine labeling is considered an accurate method to measure cell proliferation because it is a direct assay of DNA synthesis (Dolbeare, 1995). Furthermore, the antiproliferative activities could only be properly studied in a steroid-and retinoid-free medium, because of the presence of endogenous retinoids in serum. Therefore, MCF-7 cells were grown in a phenol red-free medium supplemented with charcoal-treated fetal bovine serum and growth factors.

\section{Materials and Methods}

\section{Drugs and chemicals}

ATRA was obtained from Serva (Heidelberg. Germany) and 13-cis-RA was purchased from Eastman Kodak (Rochester, New York, U.S.A.). 9-cis-RA, 4-oxo-ATRA and 5,6-epoxy-ATRA were a generous gift from Dr. M. Klaus (Hoffmann-La-Roche, Basel. Switzerland). All retinoids were dissolved in ethanol to an initial concentration of $4 \mathrm{mM}$ and appropriately diluted in culture medium. The final solvent concentration during the proliferation studies was always $<0.5 \%(\mathrm{v} / \mathrm{v})$. The retinoid stock solutions were checked for purity using HPLC analysis. Experiments with retinoids were always performed in a dark room with yellow illumination.

Preparation of dextran-coated charcoal (DCC)-treated fetal bovine serum (FBS)

DCC-treated IMBS was prepared as described by Horwitz and McGuire (1978). Briefly. FBS (Life Technologies, Palsley, United Kingdom) was heat-inactivated by a $30 \mathrm{~min}$ incubation at $56^{\circ} \mathrm{C}$. Activated charcoal $\left(0.25 \%(\mathrm{w} / \mathrm{v})\right.$. Sigma. St. Louls, U.S.A.) was coated overnight at $4^{\circ} \mathrm{C}$ with dextran $(0.025 \%(\mathrm{w} / \mathrm{v})$; Pharmacia. Uppsala. Sweden) in 0.01 M Tris/HCl (pH 8.0). Then, $100 \mathrm{ml}$ of this suspension was pelleted by centrifugation and $50 \mathrm{ml}$ heat-inactivated FBS was incubated with the resulting DCC pellet for 45 min at $45^{\circ} \mathrm{C}$. This procedure was repeated and finally the activated charcoal was removed from the FBS by centrifugation. DCC-treated FBS was sterilized by passage through a $0.22 \mu \mathrm{m}$ Millipore filter (low protein binding) and stored at $-20^{\circ} \mathrm{C}$ until use. The efficiency of this procedure was assessed by the addition of a trace amount of $\left[6,7 .{ }^{3} \mathrm{H}(\mathrm{N})\right]$ estradiol (Dupont NEN, Boston. MA. U.S.A.). [11, 12$\left.{ }^{3} \mathrm{H}(\mathrm{N})\right]$ retinol (Dupont NEN) and $\left[11,12 \cdot{ }^{3} \mathrm{H}(\mathrm{N})\right]$ ATRA (Dupont NEN). 


\section{Cell culture}

Stock cultures of MCF-7 human breast cancer cells, purchased from the American Type Culture Collection (Rockville, MD, U.S.A.), were cultured in Dulbecco's modified Eagle's medium (DMEM) with 4.5g/lter glucose supplemented with $10 \%(\mathrm{v} / \mathrm{v}) \mathrm{FBS} .2 \mathrm{mM}$ L-glutamine. $1 \mathrm{mM}$ sodum pyruvate, and $50 \mu \mathrm{g} / \mathrm{ml}$ gentamicin (all reagents from Life Technologies). The MCF-7 subclone used in this study has been characterized previously (Van heusden et al, 1996). Cells were grown in thumidified incubator (5\% $\mathrm{CO}_{2}, 95 \%$ air) at $37^{\circ} \mathrm{C}$ and were Mycoplasma-free as tested by the Mycoplasma T.C. kit (Gen-Probe Incorporated, CA. U.S.A.).

For the proliferation studies, the MCF-7 cells were cultured for 6 days in phenol red-free DMEM containing $5 \%$ (v/v) DCC-treated FBS. $4.5 \mathrm{~g} /$ liter glucose, 2 mM L-glutamine, $1 \mathrm{mM}$ sodum pyruvate, 50 $\mu \mathrm{g} / \mathrm{ml}$ gentamicin, $30 \mathrm{nM}$ sodium selenite and $10 \mu \mathrm{g} / \mathrm{ml}$ transferrin (all reagents from Life Technologies). Then cells were seeded onto Chamber Slides ${ }^{\mathrm{TM}}$ (Nunc Inc., Naperville, IL, U.S.A.) at a concentration of 15.000 cells/chamber. Chamber Slides ${ }^{\mathrm{TH}}$ had been coated with $50 \mu \mathrm{g} / \mathrm{ml}$ poly-L-lysine one day before use. Cells were allowed to attach for $24 \mathrm{~h}$ and thereafter the medium was supplemented with growth factors ( $10 \mu \mathrm{g} / \mathrm{ml}$ final concentration insulin (Life Technologies) and $5 \mathrm{ng} / \mathrm{ml}$ final concentration basic fibroblast growth factor (Life Technologles)) and retinoids (concentration ranging from $10^{-11} \mathrm{M}$ to $10^{6}$ M). Cells were grown under these conditions for 7 days, with medium changes 3 and 6 days after seeding.

\section{Bromodeoxyuridine ( $\mathrm{BrdU}$ )-detection}

After 7 days of culture with retinolds as described above, MCF-7 cells were labeled with $100 \mu \mathrm{M}$ BrdU for $2.5 \mathrm{~h}$ and fixed. Incorporated BrdU was visualized by immunofluorescence staining using the Tyramide Signal Amplification (TSA)-Direct kit (Green) (DuPont NEN Life Science Products, Boston. MA. U.S.A) as described in detail previously (Van heusden et al., 1997).

The Brdu labeling index was deftned as the proportion of BrdU-positive cells, representing cells in Sphase and was calculated by counting cells under a fluorescence microscope (Axiophot, Zeiss, Gerniany) with a dual filter set for simuitaneous visualization of fluorescein and propidium iodide signals. About 800 cells were counted twice for each test compound per experiment. Average results are presented as mean \pm SD of three or five experiments.

\section{HPLC analysis}

Confluent MCF-7 cells, cultured in medium containing 5\% DCC.treated $\mathbb{F B S}$, were treated for $24 \mathrm{~h}$ with $10^{-6}$ M ATRA to induce ATRA catabolism (Wouters et al., 199.2; Krekels et al., 1997). Cells were then washed twice with $25 \mathrm{ml}$ culture medium, trypsinized and harvested. Cells were resuspended at a concentration of $4 \times 10^{6}$ cells $/ \mathrm{ml}$. This cell suspension ( $450 \mu$ l) was incubated with $10^{7} \mathrm{M} \llbracket 11,12$ ${ }^{3} \mathrm{H}$ (N)]ATRA for different times. After centrifugation for $10 \mathrm{~min}$ at $780 \mathrm{~g}$, the supernatant was analyzed for the presence of ATRA metabolites and isomers. 
Analysis of ATRA metabolites: Reverse phase HPLC analysis was carried out on a Varian HPLC system consisting of a HPLC pump 9010, an autosampler 9095 and a diode array detector (Polyview. 9065). The Star 4.0 data software (Varian. Harbor City, CA. U.S.A.) was used to analyze the chromatograms. Radioactivity in the elluate was monitored on-line by B-counting (Packard Radiomatic radioactivity monitor) using Ultima-flo M (Packard. Meriden, CT, U.S.A.) as the scintillation solvent. The samples

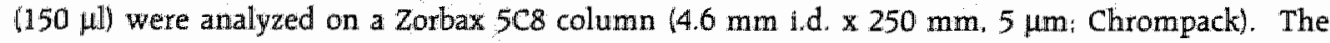
moblle phase was methanol/2\% acetic acid/acetonitrile (1.5:93:5.5) containing $40 \mathrm{mM}$ ammonium acetate (solvent A). Solvent B consisted of methanol/2\% acetic acid/acetonitrile (15:30:55) containing $40 \mathrm{mM}$ ammonium acetate and solvent $\mathrm{C}$ was $100 \%$ methanol. A linear gradient at a flow rate of $1 \mathrm{mV} /$ min was performed in 25 min from $24 \% \mathrm{~A}-76 \% \mathrm{~B}$ to $15 \% \mathrm{~A}-85 \% \mathrm{~B}$. The solvent was then changed to $50 \% \mathrm{~B}-50 \% \mathrm{C}$ in $15 \mathrm{~min}$. To elute unchanged ATRA the solvent was changed to $100 \% \mathrm{C}$ after $40 \mathrm{~min}$.

Anallysis of ATRA isomers: For the separation of the isomers of ATRA the same HPLC equipment was used. Samples ( $150 \mu l)$ were analyzed on a Novapak column $(3.9 \mathrm{~mm} 1 \mathrm{~d}$. $\times 300 \mathrm{~mm}$ ). Solvent D was methanol/2\% acetic acid/acetonitrile $(15: 30.55)$ containing $40 \mathrm{mM}$ ammonium acetate. Solvent $\mathrm{E}$ consisted of methanol/2\% acetic acid/acetonitrile (20:20:60) containing $40 \mathrm{mM}$ ammonium acetate and solvent $\mathrm{F}$ was $100 \%$ methanol. The mobile phase was $50 \% \mathrm{D}-50 \% \mathrm{E}$ for 30 min at a flow rate of 1 $\mathrm{ml} / \mathrm{miln}$. Then a linear gradient was performed to $100 \% \mathrm{~F}$

\section{Statistical analysis}

Data were analyzed using the two-tailed Mann-Whitney $U$-test using the Stat View II software (Abacus Concepts. Inc., Berkeley, CA, U.S.A.). Significance was defined at the level of ${ }^{*} p<.01$ and ${ }^{* *} p<.001$.

\section{Results}

Dextran-coated charcoal treatment of FBS efficiently removed estrogens and retinoids

The efficiency of heat inactivation and subsequent DCC-treatment to remove steroids and retinolds from FBS was assessed by the addition of trace amounts of tritiated

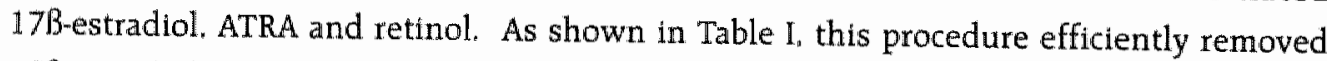
17B-estradiol and ATRA, and retinol to a lesser extent. 17B-Estradiol was removed for more than $99 \%$. ATRA for more than $93 \%$, and retinol for $64 \%$. When the tritiated compounds were preincubated with $\mathrm{FBS}$ for $24 \mathrm{~h}$ prior to DCC-treatment, similar results were obtained (data not shown). 
Table I: Efficiency of estrogen and retinoid extraction from fetal bovine serum by dextrancoated charcoal treatment

amount of tritiated label after DCC-treatment $(\%)$

\begin{tabular}{lr}
\hline 17 B-estradiol & $0.64 \pm 0.17$ \\
ATRA & $6.43 \pm 0.52$ \\
retinol & $35.78 \pm 6.78$
\end{tabular}

mean $\pm \operatorname{SD}(n=3)$

ATRA and its naturally occurring catabolites and isomers significantly inhibit MCF-7 cell proliferation

MCF-7 cells, grown in medium containing 5\% DCC-treated FBS, showed a BrdU labeling index of $8.0 \pm 1.0 \%(n=3)$. Cells were stimulated to proliferate by the addition of $10 \mu \mathrm{g} / \mathrm{ml}$ insulin and $5 \mathrm{ng} / \mathrm{ml}$ basic fibroblast growth factor. resulting in a BrdU labeling index of $25.2 \pm 1.4 \%(n=5)$.

Under these culture conditions. ATRA inhibited the proliferation of MCF-7 cells in a concentration-dependent manner, at concentrations from $10^{-8} \mathrm{M}$ to $10^{-6} \mathrm{M}$ (Fig. $2 \mathrm{~A}$ ), which was reflected by a decrease in the BrdU labeling index. At a concentration of $10^{6} \mathrm{M}$. ATRA inhibited MCF-7 cell proliferation by $61 \pm 4 \%(n=3)$.

Figure $2 \mathrm{~B}$ shows that the ATRA catabolite 4-0xo-ATRA decreased the labeling index at concentrations ranging from $10^{-8} \mathrm{M}$ to $10^{-6} \mathrm{M}$. At a concentration of $10^{-6} \mathrm{M}$. cell proliferation was inhibited by $37 \pm 11 \%(n=5)$.

5.6-epoxy-ATRA, another catabolite of ATRA, decreased the BrdU labeling index at $10^{-8} \mathrm{M}$ to $10^{-6} \mathrm{M}$ to the same extent as 4-oxo-ATRA (Fig. 20).

The stereoisomer 9-cis-RA (Fig. 2D) also inhibited MCF-7 cell proliferation concentrationdependently $\left(10^{-8} \mathrm{M}\right.$ to $\left.10^{6} \mathrm{M}\right)$. Note that 9-cis-RA was equipotent as compared to ATRA at all concentrations tested.

Figure $2 \mathrm{E}$ shows the antiproliferative activity of the stereoisomer 13-cis-RA. At concentrations ranging from $10^{-8} \mathrm{M}$ to $10^{-6} \mathrm{M}, 13$-cis-RA decreased the $\mathrm{BrdU}$ labeling index to the same extent as the ATRA catabolites 4-oxo-ATRA and 5.6-epoxy-ATRA. 

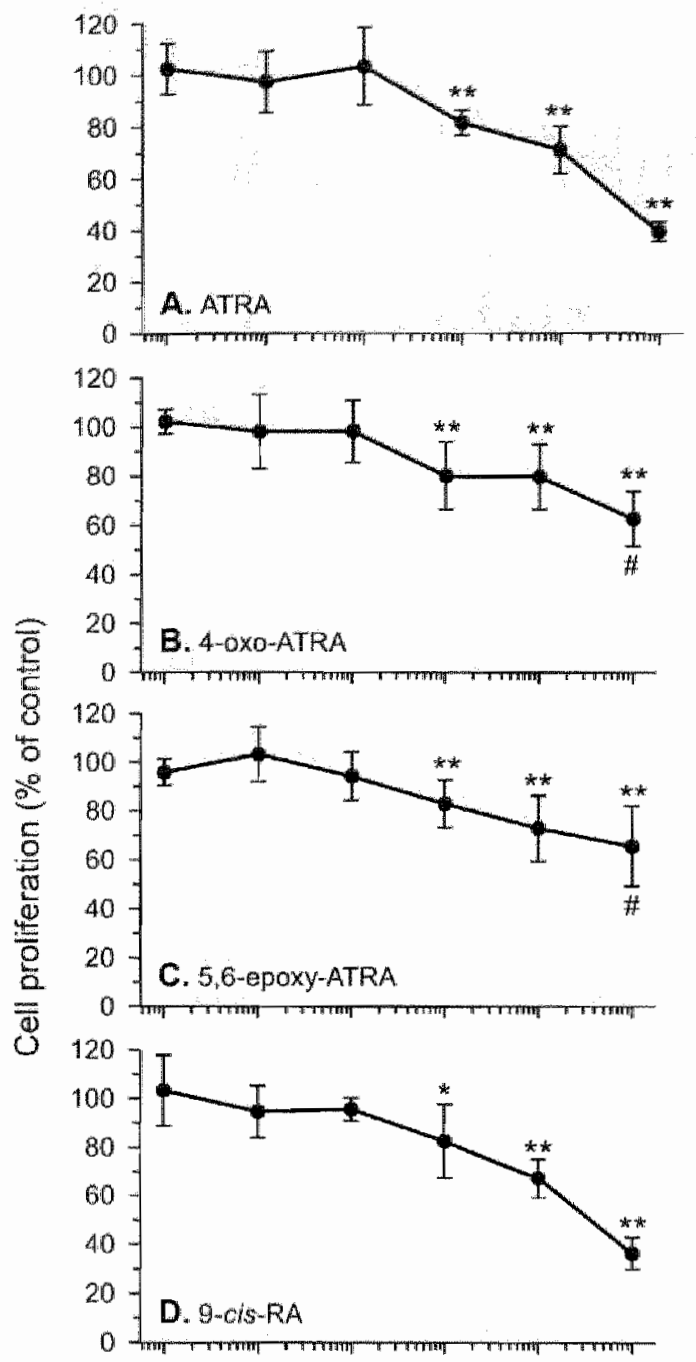

Figure 2: Concentrationresponse curves showing the antiproliferative activity of ATRA (A), its catabolites 4-oxo-ATRA (B) and 5,6-epoxy-ATRA (C) and its isomers 9-cis-RA (D) and 13cis-RA (E) in MCF-7 cells. Cells were cultured for 7 days in the presence of test compounds. Cell proliferation was measured by BrdU incorporation, as described in "Materials and Methads". Results are presented as mean \pm SD of three ( $A$, $D, E)$ or five $(B, C)$ experiments. $p<.01$ and $p<.001$ versus control cells (Mann-Whitney $U$ test). ${ }^{\#} p<.01$ versus ATRAtreated cells (Mann-Whitney $U$ test).

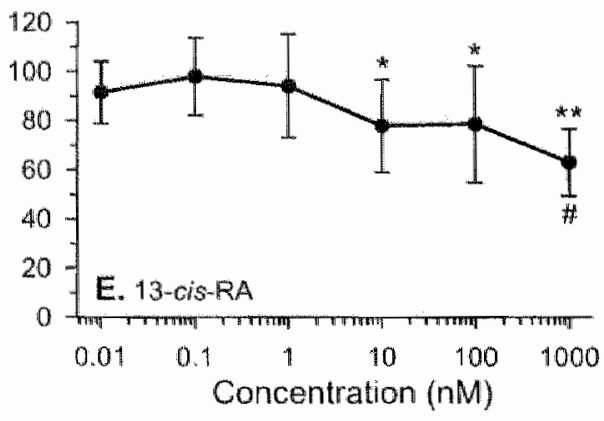




\section{In vitro metabolism and isomerization of ATRA in MCF-7 cells}

MCF-7 cells, grown in medium containing $5 \%$ DCC-treated FBS. were pretreated for $24 \mathrm{~h}$ with $10^{-6} \mathrm{M}$ ATRA to induce ATRA catabolism. Cells were then incubated with $10^{-7} \mathrm{M}{ }^{3}$ HATRA for $4 \mathrm{~h}$ and the supernatant was analyzed for the presence of labeled ATRA catabolites and isomers by HPLC analysis. As shown in Figure 3A. MCF-7 cells converted ATRA into very polar metabolites (retention time: $2-11 \mathrm{~min}$ ) and several metabolites of intermediate polarity (retention time: 16-25 min). In the absence of cells no polar metabolites could be detected (data not shown). Combined, the intermediate and very polar metabolites accounted for about $60 \%$ of total recovered radioactivity. Peaks were detected (Fig. $3 \mathrm{~A}$ ) co-eluting with authentic 4-hydroxy-ATRA (retention time: $19 \mathrm{~min}$ ) and 4-oxo-ATRA (retention time: $20.3 \mathrm{~min})$. Figure 4 shows that the intermediate polar metabolites were formed to only a limited extent (less than 10\%) and their amount did not increase as a function of time.

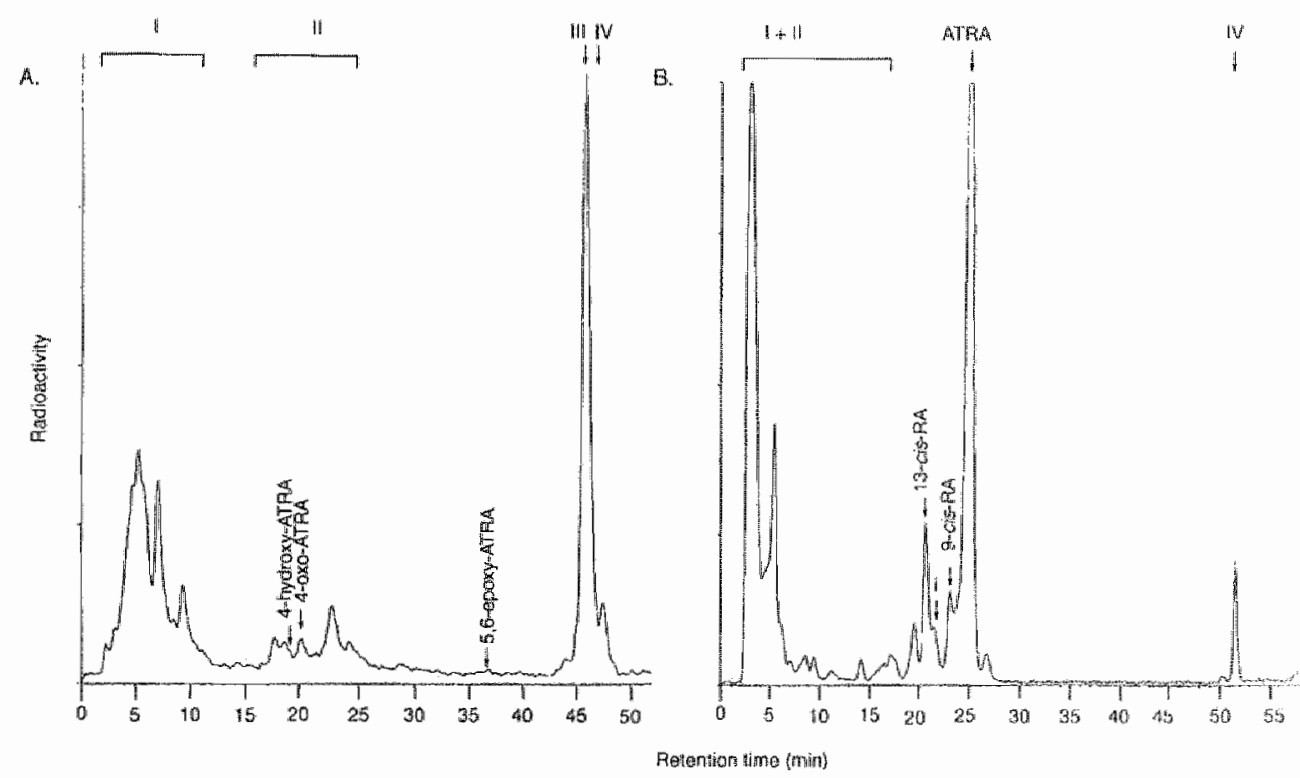

Figure 3: Chromatograms illustrating the metabolism of ATRA in MCF-7 cells grown in medium containing $5 \%$ DCC-treated FBS. Cells were incubated for $24 \mathrm{~h}$ with $10^{-6} \mathrm{M}$ ATRA to induce ATRA catabolism, washed twice and collected. Cells were then incubated for $4 \mathrm{~h}$ with $10^{-7} \mathrm{M}\left[{ }^{3} \mathrm{H}\right] \mathrm{ATRA}$ and the supernatant was analyzed by reverse phase HPLC for the presence of catabolites (A) and isomers (B). I: very polar metabolites. II: intermediate polar metabolites. III: unchanged RA. IV: apolar peak. 


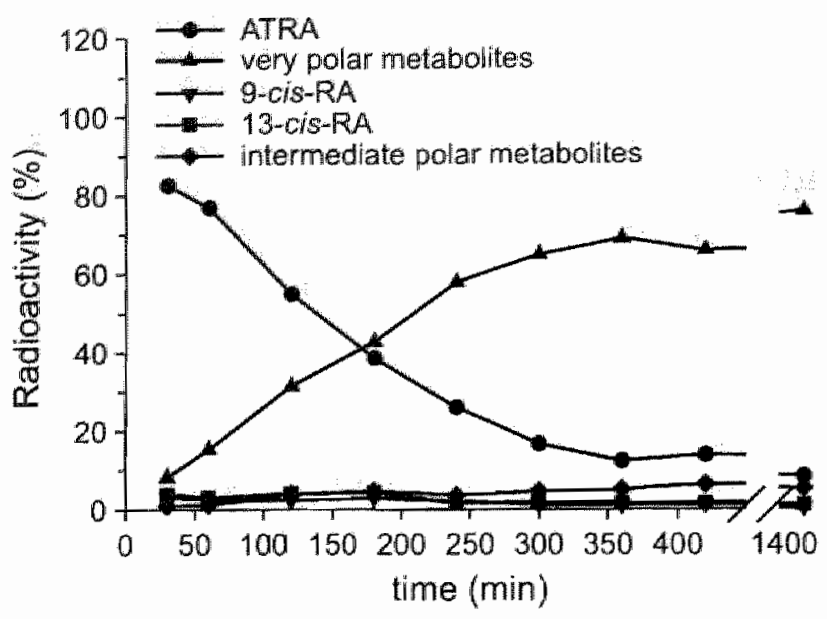

Figure 4: Metabolism and isomerization of ATRA in MCF-7 cells grown in medium containing $5 \%$ DCC-treated FBS. Cells were incubated for $24 \mathrm{~h}$ with $10^{-6} \mathrm{M}$ ATRA to induce ATRA catabolism, washed twice and collected. Cellls were then incubated for various times with $10^{-7} \mathrm{M}$ $\left[{ }^{3} \mathrm{H}\right] \mathrm{ATRA}$ and the supernatant was analyzed by reverse phase HPLC for the presence of catabolites and isomers.

Increasing amounts of very polar metabolites were formed from ATRA as a function of time (Fig. 4). No peak co-eluting with authentic 5.6-epoxy-ATRA (retention time: 37 min) could be detected in the culture medium of cells that were pretreated to induce ATRA catabolism (Fig. 3A). In the culture medium of cells that were not pretreated with ATRA or in the absence of cells, 5.6-epoxy-ATRA could not be detected at time points ranging from 30 min to $24 \mathrm{~h}$ (data not shown). Other polar metabolites were present in the cell culture medium (Fug. 3A) but their nature remains to be identified. MCF-7 cells also converted ATRA into an apolar metabolite, that was not detected in the absence of cells.

Figure $3 \mathrm{~B}$ shows the isomers of ATRA that were formed when MCF-7 cells, pretreated for $24 \mathrm{~h}$ with $10^{-6} \mathrm{M}$ ATRA, were incubated with $10^{-7} \mathrm{M}\left[{ }^{3} \mathrm{H}\right]$ ATRA. After $4 \mathrm{~h}$, only about $30 \%$ of total radioactivity was recovered in the RA peak. 1.e. ATRA and its stereoisomers 9-cis-RA and 13-cis-RA. This RA peak consisted for about 83\% of ATRA, 8\% of 13-cis-RA and 7\% of 9-cis-RA. Similar isomer composition of the RA peak was obtained with cells that were not pretreated with ATRA and in the absence of cells (data not shown). After $24 \mathrm{~h}$, only about $11 \%$ of total radioactivity was recovered in the RA peak of $\mathrm{MCF}-7$ cells that were pretreated with ATRA (Fig, 4). In the absence of cells about $80 \%$ of total radioactivity was recovered in the RA peak (data not shown). Under both culture conditions, the relative isomer compositon was about 71\% ATRA, 12\% 13-cis-RA and 8\% 9-cis-RA. An additional peak (peak i. Fig. 3B) could be detected but its nature remains unknown. 


\section{Discussion}

The present study demonstrates that not only ATRA itself, but also its naturally occurring catabolites 4-oxo-ATRA and 5.6-epoxy-ATRA as well as its isomers 9-cis-RA and 13-cis-RA possess significant antiproliferative activity in MCF-7 human breast cancer cells. grown in a steroid- and retinoid-free medium. A significant antiproliferative activity equal to that of ATRA, was observed with these catabolites and isomers at concentrations of $10^{-8} \mathrm{M}$ and $10^{-7} \mathrm{M}$. At a concentration of $10^{-6} \mathrm{M}$, the ATRA catabolites and the stereoisomer 13-cis-RA were less potent than ATRA. The stereoisomer 9-cis-RA was as potent as ATRA at all concentrations tested $\left(10^{-11} \mathrm{M}\right.$ to $\left.10^{-6} \mathrm{M}\right)$. Since these catabolites and isomers were formed to only a limited extent, our findings suggest that they cannot be responsible for the observed growth inhibition induced by ATRA.

The antiproliferative activity of ATRA and its naturally occurring catabolites and isomers could only be properly studied in a steroid-and retinoid-free culture medium. For this purpose. phenol red-free medium (Berthois et al. 1986) was used supplemented with DCCtreated FBS (Horwitz and McGuire, 1978). DCC-treatment of FBS is well-known to remove endogenous steroids present in the serum (Horwitz and McGuire, 1978). In this study, we showied that also ATRA was efficiently removed by DCC-treatment. This would result in a final concentration of $1.3 \times 10^{-11} \mathrm{M}$ to $4.5 \times 10^{-11} \mathrm{M}$ ATRA in the culture medium, calculated from ATRA levels present in human plasma, i.e. 4-14 nM. Up to now, only indirect evidence suggested that retinoids could be removed from the serum by DCC-treatment (Mummery et al., 1991). Retinol, a possible source of RA, was harder to extract and about 40\% could not be removed. We assumed that the remaining amount of retinol did not interfere with our results since MCF-7 cells are unable to convert retinol into ATRA (Krekels et al., 1997).

The antineoplastic activity of synthetic retinoids, such as for example $N$-(4-hydroxyphenyl)retinamide, has been amply described. In contrast. limited and conflicting results have been reported about the activity of naturally occurring ATRA metabolites in tumor cells. The catabolite 4-oxo-ATRA has been shown to bind to RARs (Pijnappel et al., 1993). Furthermore, both 4-oxo-ATRA and 5,6-epoxy-ATRA can activate RAR-dependent gene transcription in cotransfected CV-1 cells (Duell et al., 1992). However. their activity in our study was higher than would have been expected from previous reports where these catabolites were found to be less potent than ATRA in $i)$ the inhibition of growth and the inhibition of hormone-isobutylmethylxanthine-inducible tyrosinase activity 
of Cloudman S-91 mouse melanoma cells (Lotan et al., 1980: Reynolds et al., 1993). ii) the induction of differentiation of $F 9$ mouse teratocarcinoma cells as measured by an ELISA for laminin (Williams et al. 1987) and iii) the induction of differentiation and inhibition of proliferation of BA-HAN-1C rat rhabdomyosarcoma cells (Ramp et al. 1994). On the other hand both catabolites have been reported to be virtually inactive (Frolik et al., 1979: Silva et al. 1987), In our MCF-7 model system, the catabolites 4-oxo-ATRA and 5,6-epoxy-ATRA were as potent as ATRA at concentrations of $10^{-8} \mathrm{M}$ and $10^{7} \mathrm{M}$, but were twofold less potent at $10^{-6} \mathrm{M}$. It is clear that a complex phenomenon is occurring for which there is no obvious explanation. It is very unlikely that the observed antiproliferative activity of 4-oxo-ATRA and 5,6-epoxy-ATRA was due to conversion back to ATRA, since the reactions involved in their formation are irreversible (Roberts et al., 1980; Napoli et al., 1982). Although conversion to other active retinoids is conceivable. such compounds have yet to be identified (Reynolds et al. 1993). Up to now only in non-tumor models namely in a model of positional specification (Pijnappel et al.. 1993) and in spermatogonia (Gaemers et al.. 1996), 4-oxoATRA has been shown to be as potent as ATRA.

ATRA catabolism, under the present culture conditions, was induced to the same extent as previously described (Wouters et al.. 1992; Krekels et al., 1997). Only the supernatant was analyzed for the presence of ATRA metabolites and isomers. We have previously shown that in the cell extract the same overall metabolite profile can be found (Wouters et al.. 1992). By HPLC analysis peaks were identified that co-eluted with authentic 4-hydroxyATRA and 4-oxo-ATRA. No 5,6-epoxy-ATRA could be detected under basal culture conditions nor after induction of ATRA catabolism, indicating that 5,6-epoxy-ATRA was either not formed in vitro or formed in quantities below the detection limit. Therefore, it is rather unlikely that 5.6-epoxidation is a major catabollic pathway of ATRA in MCF-7 cells. In addition, other polar metabolites could be detected but their nature remains to be elucidated. We cannot exclude the possibility that these metabolites possess antiproliferative activity. In this context it is interesting to remark, however, that we have shown previously that the antiproliferative activity of ATRA can be enhanced by the addition of an inhibitor of ATRA catabolism (Wouters et al. 1992: Van heusden et al., 1996), suggesting that catabolism of ATRA is not necessary to inhibit MCF-7 cell proliferation. The exact nature of the apolar peak. which has been described previously (Wouters et al.. 1992). remains to be determined.

Recently. Takatsuka et al. (1996) showed a positive relationship between ATRA-induced growth inhibition of human breast cancer cells and intracellular ATRA metabolism. suggesting 
that a metabolite of ATRA, rather than the parent compound itself could be responsible for the observed growth inhibition. It is important to note. however, that these experiments were conducted under serum-free conditions, resulting in an altered bioavailability of RA to cells (Hodam and Creek, 1996). Our data showed that 4-oxo-ATRA and 5.6-epoxy-ATRA are strong inhibitors of MCF-7 cell proliferation. However, since 5.6-epoxy-ATRA could not be identified in our cell culture system and 4-oxo-ATRA was formed to only a limited extent. our results do not favour the hypothesis that these catabolites are responsible for the observed growth inhibition when given ATRA.

The ability of ATRA to isomerize in cell culture (Urbach and Rando. 1994) further complicates the interpretation of its antiproliferative activity. In the present study, isomerization of ATRA to 9-cis-RA and 13-cis-RA was also observed, but only to a limited extent. This process was not enzymatic since it also occured in the absence of cells. in agreement with previous results (Urbach and Rando, 1994). The major isomer detected was the all-trans form of RA. The naturally occurring stereoisomer 9-cis-RA acts as a pan agonist that can bind and activate both RARs and RXRs (Chambon. 1996). 9-cis-RA was equipotent to ATRA in inhibiting MCF-7 cell proliferation at all concentrations tested, in agreement with previous reports (Rubin et al., 1994). The ability of the naturally occurring stereoisomer 13-cis-RA to bind and transactivate RARs is controversial. The antiproliferative activity of 13-cis-RA has been described to be less (Redfern et al., 1990) or equal (Frey et al., 1991) to that of ATRA. In our experiments, 13-cis-RA, at concentrations of $10^{-8} \mathrm{M}$ and $10^{-7} \mathrm{M}$, was equipotent to ATRA in inhibiting the growth of MCF-7 cells, in agreement with previous reports (Frey et al.. 1991) and with its therapeutic effect in some forms of cancer.

In conclusion, we can state that the naturally occurring catabolites and isomers of ATRA. show significant antiproliferative activity in MCF 7 human breast cancer cells. However. since these catabolites and isomers were formed from ATRA to only a limited extent. our findings suggest that they cannot be responsible for the observed growth inhibition induced by ATRA.

\section{Acknowledgements}

We are very grateful to Dr. M. Klaus (Hoffmann-La-Roche, Basel, Switzerland) for the generous gift of the retinoids. We thank Hélène Bruwiere. Willy Cools and Anja Verhoeven for technical assistance. The photographic layout by Lambert Leijssen and colleagues is also acknowledged. 


\section{References}

Berthois, $Y_{\text {, }}$ Katzenellenbogen, J.A., and Katzenellenbogen, B.S. Phenol red in tissue culture media is a weak estrogen: implications concerning the study of estrogen-responsive cells in culture. Proc. Nadl Acad. Sci. U.S.A. 83: 2496-2500, 1986.

Bhat, P.V, and Lacroix, A. Metabolism of retinol and retinoic acid in $N$-methyl $N$-nitrosourea-induced manmary carcinomas in rats. Cancer Res. 49: 139-144, 1989.

Biesalski, H.K., Brodda, K., Gabbert, H.E., Gerharz, C.-D., Engers, R., Häussermann, B., Koller, H., Weiser, H, and Bässler, K.H. Uptake and metabolism of retinoic acid induces inhibition of cell growth: a study in a rat thabdomyosarcoma cell line (BA-HAN-1C) using nonlinear theoretical models. Internat. J. Vit. Nutr. Res. 60: 4-18, 1990.

Chambon, P. A decade of molecular biology of retinoic acid receptors. FASEB J. 10:940-954, 1996.

Dolbeare, F. Bromodeoxyuridine: a diagnostic tool in biology and medicine. Part 1: Historical perspectives. histochemical methods and cell kinetics. Histochem. ]. 27: 339-369. 1995.

Duell, E.A., Aström, A., Griffiths, C.E., Chambon, P, and Voorhees, I.). Human skin levels of retinoic acid and cytochrome P450-derived 4-hydroxy-retinoic acid after topical application of retinoic acid in vivo compared to concentrations required to stimulate retinoic acid receptor-mediated transcription in vitro. J. Clin. Invest. 90; 1269-1274, 1992.

Frey, J,R., Peck, $R$, and Bollag, W. Antiproliferative activity of retinoids, interferon and their combination in five human transformed cell lines. Cancer Lett, 57: 223-227. 1991.

Frolik, C.A., Roberts, A.B., Tavela, T.E. Roller, P.P., Newton, D.L., and Sporn, M.B. Isolation and identification of 4-hydroxy-and 4-oxo-retinoic acid. In witro metabolites of all-trans-retinoic acid in hamster trachea and liver. Biochemistry 18: 2092-2097, 1979.

Gaemers, I.C.. van Pelt, A.M.M., van der Saag, P.T., and de Rooij, D.G. All-trans4-oxo-retinolc acid: a potent inducer of in wivo proliferation of growth-arrested A spermatogonia in the vitamin A-deficient mouse testis. Endocrinology 137: 479-485. 1996.

Gudas, L.J., Sporn. M.B., and Roberts. A.B. Cellular biology and biochemistry of the retinolds. In: Sporn, M.E., Roberts. A.B., Goodman, D.S. (eds.). The Retinoids. Biology. Chemistry and Medicine. Ed. 2. pp. 443-520. Rawen Press: New York, 1994.

Han. I.S., and Choi, J.H. Highly specific cytochrome P450-like enzymes for all-trans-retinoic acid in T470 human breast cancer cells. J. Clin. Endocrinol. Metab. 81: 2069-2075, 1996.

Hodam, J.R. and Creek, K.E. Uptake and metabolism of [ $\left.{ }^{3} \mathrm{H}\right]$ retinoic acid delivered to human foreskin keratinocytes either bound to serum albumin or added directly to the culture medium. Biochim. Biophys. Acta 1311: 102-110, 1996.

Horwitz $\mathrm{K}_{\mathrm{B}}$., and MCGuire, W.L. Estrogen control of progesterone receptor in human breast cancer. J. Biol. Chem. 253: 2223-2228, 1978 . 
Krekels, M.D.W.G. Zimmerman. J. Janssens, B., Van Ginckel R. Cools, W. Van Hove; C., Coene, M. C., and Wouters. W. Analysis of the oxidative catabolisn of retinolc acid in rat Dunning $\mathrm{R} 3327 \mathrm{G}$ prostate tumors. Prostate 29: 36-41, 1996.

Krekels, M.D.W.G., Verhoeven, A., wan Dun, J., Cools, W. Van Hove, C., Dillen, L., Coene, M.-C., and Wouters. W. Induction of the oxidative catabolism of retinoic acid in MCF-7 cells. Br. I. Cancer 75: 1098-1104, 1997.

Lotan, R. Neumann, G., and Lotan. D. Relationships among retinoid structure inhibition of growth. and cellular retinoic acid-binding proteins in cultured S91 melanoma cells. Cancer Res. 40:1097$1102,1980$.

McCormick. A.M. Napoli, J.L., Schnoes, H.K. and DeLuca, H.F. Isolation and identification of 5.6epoxy-retinoic acid: A biologically active metabolite of retinoic acid. Biochemistry 17: 4085$4090,1978$.

Moon, R.C., Mehta, R.G., and Rao, K.V.N. Retinoids and cancer in experimental animals. In: Sporn, M.B., Roberts, A.B., Goodman, D.S. (eds.), The Retinotds. Biology, Chemistry and Medicine, Ed. 2. pp. 573-595. Raven Press: New York, 1994.

Mummery . C.L., van Achterberg, T.A.E., van de Eijnden-van Raaij, A.J.M. van Haaster, L., Willemse, A. de Laat, S.W, and Piersma. A.H. Visceral-endoderm-like cell lines induce differentiation of murine P19 embryonal carcinoma cells. Differentiation 46: 51-60, 1991.

Napoli, J.L., Khalil, H, and McCormick. A.M. Metabolism of 5.6-epoxyretinoic acid in vitw: isolation of a major intestinal metabolite. Biochemistry 21: 1942-1949. 1982.

Napoli. J.L. Retinol metabolism in LLC-PK, cells. Characterization of retinoic acid synthesis by an established mammalian cell line. J. Biol. Chem. 261: 13592-13597, 1986.

Napoli. J.L. Regulation of the biosynthesis and catabolism of retinoids. FASEB J. 10: 993-1001, 1996.

Pijnappel. W.W.M., Hendriks, H.F.J., Folkers, G.E., van den Brink, C.E., Dekker, E.J., Edelenbosch, C., van der Saag, P.T., and Durston. A.J. The retinoid ligand 4-oxo-retinoic acid is a highly active modulator of positional specification. Nature (London) 366: 340-344. 1993.

Ramp, U., Gerharz, C.D., Eifler, E., Biesalski, H.K. and Gabbert, H.E. Effects of retinoic acid metabolites on proliferation and differentiation of the clonal thabdomyosarcoma cell line BA-HAN-1C. BIol. Cell 81: 31-37, 1994 .

Redfern. C.P. Daly, A.K., Latham. J.A., and Todd, C. The biological activity of retinoids in melanoma cells. Induction of expression of retinoic acid receptor- $B$ by retinotc acid in $\$ 91$ melanoma cells. FEBS Lett. 273: 19-22. 1990.

Reynolds. N.J.. Fisher, G.J., Griffiths, C.E.M., Tavakkol, A., Talwar, H.S., Rowse, P.E., Hamilton, T.A., and Voorhees. J.J. Retinoic acid metabolites exhibit biological activity in human keratinocytes. mouse melanoma cells and hatrless mouse skin in vivo. J. Pharmacol. Exp. Ther. 266: 1636-1642. 1993. 
Roberts, A.B., Lamb, LC., and Sporn, M.B. Metabolism of all-trans-retinoic acid in hamster liver microisomes: oxidation of 4hydroxy- to 4-keto-retinoic acid. Arch. Biochem. Biophys. 199:374 383.1980.

Rubin, M., Fenig. E., Rosenauer, A., Menendez-Botet, C., Achkar, C. Bentel, J.M., Yahalom. I. Mendelsohn, J, and Miller. W.H.Jr, 9-cis-Retinoic acid inhibits growth of breast cancer cells and down-regulates estrogen receptor RNA and protein. Cancer Res. 54:6549-6556. 1994.

Silva, D.P. Valliere, C.R., and DeLuca, H.E. Lack of biological activity of physiological metabolites of all-trans-retinoic acid on waginal epithelial differentiation. Arch. Biochem. Biophys. 259: 391401. 1987.

Takatsuka, J., Takahashi. N., and De Luca, L.M. Retinoic acid metabolism and inhibition of cell proliferation: an unexpected liarson. Cancer Res. 56: 675-678. 1996.

Urbach, J., and Rando, R.R. Isomerization of all-trans-retinoic acid to 9-cis-retinoic acid. Biochem. J. 299: 459-465, 1994 .

Van heusden, J., Borgers, M., Ramaekers, F, Xhonneux, B., Wouters, W. De Coster, R., and Smets, G. Liarozole potentiates the all-trans-retinoic acid-induced structural remodelling in human breast carcinoma MCF-7 cells in vitro. Eur J. Cell Biol. 71:89-98, 1996.

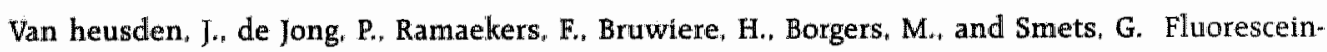
labeled tyramide strongly enhances the detection of low bromodeoxyuridine-incorporation levels. J. Histochem. Cytochem. 45: 315-319, 1997.

Van Wauwe, J., Coene, M. C. Cools, W. Goosens, J., Lauwers, W., Le Jeune, L., Van Hove, C., and Van Nyen. G. Liarozole-fumarate inhibits the metabolism of 4 keto-all-trans-retinoic acid. Biochem. Pharmacol. 47: 737-741, 1994 .

White, J.A., Guo, Y.-D., Baetz. K., Beckett-Jones, B., Bonasoro, J. Hsu, K.E., Dilworth, F.J., Jones, G.. and Petkovich, M. Identification of the retinoic acid-inducible all-trans-retinoic acid 4-hydroxylase. J. Biol Chem 271:29922-29927, 1996.

Williams, J.B., and Napoli, J.L. Metabolism of retinoic acid and retinol during differentiation of F9 and embryonal carcinoma cells. Proc. Natl. Acad. Sci. U.S.A. 82: 4658-4662. 1985.

Williams, J.B., Shields, C.O., Brettel, L.M., and Napoli, J.L. Assessment of retinoidninduced differentiation of $\mathrm{Fg}$ embryonal carcinoma cells with an enzyme-linked immunoadsorbent assay for laminin: statistical comparison of dose-response curves. Anal. Biochem. 160: 267-274, 1987.

Wouters, W., van Dun. J, Dillen, A., Coene, $M_{n}-$ C., Cools, W., and De Coster, R. Effects of liarozole. a new antitumor compound, on retinoic acid-induced inhibition of cell growth and on retinoic acid metabolism in MCF.7 human breast cancer cells. Cancer Res. 52: 2841-2846, 1992. 

\& 


\section{The antiproliferative activity of all-trans-retinoic acid catabolites and isomers is differentially modulated by liarozole-fumarate in MCF-7 human breast cancer cells}

Br. J. Cancer, in press.

Jimmy Van heusden ${ }^{1}$, Walter Wouters ${ }^{2}$, Frans C.S. Ramaekers ${ }^{1}$, Marita D.W.G. Krekels $^{2}$, Lieve Dillen ${ }^{3}$, Marcel Borgers ${ }^{1,4}$ and Gerda Smets ${ }^{2}$

"Department of Molecular Cell Biology \& Genetics, University of Maastricht, P.O. Box 616,6200 MD Maastricht. The Netherlands: ${ }^{2}$ Departments of Oncology, ${ }^{3}$ Immunology and ${ }^{4}$ Morphology. Janssen Research Foundation. Turnhoutseweg 30. B-2340 Beerse. Belgium

\section{Abstract}

The clinical use of all-trans-retinoic acid (ATRA) in the treatment of cancer is significantly hampered by the prompt emergence of resistance, believed to be caused by increased ATRA catabolism. Inhibitors of ATRA catabolism may therefore prove valuable for cancer therapy. Liarozole-fumarate is an antitumor drug that inhibits the cytochrome P450-dependent catabolism of ATRA. ATRA, but also its naturally occurring catabolites, 4-oxo-ATRA and 5.6-epoxy-ATRA, as well as its stereoisomers, 9-cis-RA and 13-cis-RA, show significant antiproliferative activity in MCF-7 human breast cancer cells. In 


\section{Chapter 6}

order to further elucidate its mechanism of action, we investigated whether liarozole-fumarate was able to enhance the antiproliferative activity of ATRA catabolites and isomers. Liarozole-fumarate alone up to a concentration of $10^{-6} \mathrm{M}$ had no effect on MCF-7 cell proliferation. However, in combination with ATRA or the ATRA catabolites, liarozole-fumarate $\left(10^{-6} \mathrm{M}\right)$ significantly enhanced their antiproliferative activity. On the contrary, liarozole-fumarate $\left(10^{-6} \mathrm{M}\right)$ was not able to potentiate the antiproliferative activity of the ATRA stereoisomers, most probably because of the absence of cytochrome P450dependent catabolism. Together, these findings show that liarozole-fumarate acts as a versatile inhibitor of retinoid catabolism in that it not only blocks the breakdown of ATRA, but also inhibits the catabolic pathway of 4-oxoATRA and 5,6-epoxy-ATRA, thereby enhancing their antiproliferative activity.

\section{Introduction}

The therapeutic potential of all-trans-retinoic acid (ATRA) in cancer is obvious from a vast number of publications (for review see Hong and Itri. 1994; Moon et al., 1994). However, a major drawback to the clinical application of ATRA is the prompt emergence of resistance, most probably because of the induction of oxidative catabolism through cytochrome P450dependent enzymes (Muindi et al., 1992; Smith et al., 1992; Warrell et al., 1993. Warrell. 1993; Kizaki et al. 1996).

Liarozole-fumarate, an imidazole-containing antitumor drug, was recently identified as an inhibitor of cytochrome P450-dependent RA catabolism (Van Wauwe et al., 1990, 1994; Wouters et al. 1992; Krekels et al.. 1996). In vivo. liarozole-fumarate showed retinoidmimetic effects (Van Wauwe et al., 1991: Smets et al., 1995: Mahler et al., 1993). In animals. the drug reduced the growth of both androgen-dependent and androgen-independent Dunning R3327 rat prostate adenocarcinoma cells (Van Ginckel et al., 1990; Dijkman et al. 1994: Smets er al. 1995), and of androgen-independent PC-3ML-B2 human prostate carcinoma xenografts (Stearns et al. 1993). In the Dunning AT-6sq an androgen-independent rat prostate carcinoma, liarozole-fumarate reduced tumor weight, and concomitantly increased ATRA levels both in plasma and tumors, resulting in a shift of their differentiation status (Smets et al. 1995). In patients, the drug is currently being tested in phase III clinical trials for the treatment of relapsed prostate cancer (Mahler et al.. 1993; Wouters, 1994). In vitro. liarozole-fumarate has no intrinsic retinoid-like activity, but enhances the beneficial 
effects of ATRA, most probably by inhibiting catabolism. The drug has been shown to potentiate the antiproliferative activity of ATRA in MCF-7 human breast cancer cells (Wouters et al., 1992; Van heusden et al., 1996) and to enhance the differentiation-inducing capacity of ATRA in F9 mouse teratocarcinoma cells (De Coster et al. 1992) and MCF-7 cells (Van heusden et al. 1996). The cancer chemopreventive activity of ATRA and B-carotene was potentiated in 10T1/2 mouse embryonal fibroblasts (Acevedo and Bertram. 1995) and retinoidinduced apoptosis was enhanced in DU145 human prostate cancer cells (Hall. 1996).

ATRA is well known to inhibit proliferation and to induce differentiation of malignant cells (Lotan, 1980). ATRA is rapidly metabolized in a catabolic pathway that includes the 4hydroxylation of the B-ionone ring to yield 4-hydroxy-ATRA (Frolik et al., 1979; Roberts $e$. al., 1980). This step is catalyzed by a cytochrome P450-dependent ATRA 4-hydroxylase (Roberts et al. 1980; White et al., 1996). 4-Hydroxy-ATRA is then converted to more polar metabolites via 4-oxo-ATRA (Roberts et al.. 1980), involving at least one, presently unknown, cytochrome P450-dependent enzyme (Roberts et al. 1980; Van Wauwe et al., 1994). Other catabolic pathways of ATRA have been described including epoxidation to yield 5,6-epoxyATRA (McCormick et al., 1978: Barua et al., 1991). Also, ATRA can isomerize in cell culture to 9-cis-RA and 13-cis-RA, an obviously non-enzymatic process (Urbach and Rando, 1994). ATRA and its naturally occurring catabolites and isomers possess significant antiproliferative activity in MCF-7 cells (Van heusden et al., 1997b). To further explore the mechanism of action, we studied whether liarozole-fumarate was able to enhance the antiproliferative activity of these naturally occurring ATRA catabolites and isomers.

\section{Materials and Methods}

\section{Drugs and chemicals}

The fumarate salt of liarozole. $\{ \pm-5$-[(3-chlorophenyl) $(1 \mathrm{H}$-imidazole-1-yl) methyl]-1H-benzimidazole (E)-2-butenedioate (2:3)\} (R085246), was synthesized at the Janssen Research Foundation (Beerse, Belgium). ATRA was obtained from Serva (Heidelberg, Germany) and 13-cis-RA was purchased from Eastman Kodak (Rochester. NY. U.S.A.). 9-cis-RA, 4-oxo-ATRA and 5,6-epoxy-ATRA were generous gifts from Dr. M. Klaus (Hoffmann-La-Roche, Basel, Switzerland). Stock solutlons of liarozole-fumarate (10 $\mathrm{mM})$ and retinoids ( $4 \mathrm{mM}$ ) were prepared in ethanol and appropriately diluted in culture medium. The final ethanol concentration did not exceed $0.5 \%(\mathrm{v} / \mathrm{v})$. The retinoid stock solutions were checked for purity using HPLC analysis. Experimental studies with retinoids were always performed in a dark room with yellow illumination. 


\section{Preparation of dextran-coated charcoal (DCC)-treated fetal bovine serum} (EBS)

DCC-treated FBS was prepared as described by Howwtz and MCGuire (1978). Briefly. FBS (Life Technologies, Paisley, United Kingdom was heat-inactivated by a 30 min incubation at $56^{\circ} \mathrm{C}$. Activated charcoal $10.25 \%$ (w/v); Sigma Chemical Co. St. Louis, MO. U.S.A.) was coated overnight at $4^{\circ} \mathrm{C}$ with dextran 60.025\% (w/w): Pharmacia. Uppsala. Sweden) in $0.01 \mathrm{M}$ Tris/HCl (pH 8.0). Then. $100 \mathrm{ml}$ of this suspension was pelleted by centrifugation and $50 \mathrm{ml}$ heat-inactivated FBS was incubated for $45 \mathrm{~min}$ at $45^{\circ} \mathrm{C}$ with the resulting DCC pellet. This procedure was repeated and finally the activated charcoal was removed from the FBS by centrifugation. DCC-treated FBS was sterilized by passage through a $0.22 \mu \mathrm{m}$ Millipore filter (low protein binding) and stored at $-20^{\circ} \mathrm{C}$ until use. The efficiency of this procedure was assessed by the addition of a trace a mount of $\left[6,7^{3} \mathrm{H}(\mathrm{N})\right]$ estradiol (DuPont NEN, Boston. MA, U.S.A.). [11, $12^{3}$ F(N)]retinol (DuPont NEN) and $\left[1,1,2^{3}\right.$ H(N)]ATRA (DuPont NEN). The DCCtreatment efficiently removed estradiol and ATRA, and retinol to a lesser extent (Van heusden $a t$ al. $19976 \%$.

\section{Cell culture}

Stock cultures of $\mathrm{MCF}-7$ human breast cancer cells, purchased from the American Type Culture Collection (Rockville, MD, U.S.A.), were cultured in Dulbecco"s modified Eagle's medium (DMEM) with $4.5 \mathrm{~g} / \mathrm{liter}$ glucose supplemented with $10 \%(\mathrm{v} / \mathrm{v})$ FBS, $2 \mathrm{mM}$ L-glutamine. $1 \mathrm{mM}$ sodium pyruvate and $50 \mu \mathrm{g} / \mathrm{ml}$ gentamicin (all reagents from Life Technologies). The MCF-7 subclone used in this study has been characterized previously (Van heusden et al. 1996). Cells were grown in a humidified incubator (5\% $\mathrm{CO}_{2}, 95 \%$ air) at $37^{\circ} \mathrm{C}$ and were Mycoplasma-free as tested by the Mycoplasma T.C. kit (Gen-Probe Incorporated, CA, U.S.A.).

For the proliferation studies. MCF-7 cells were cultured for 6 days in phenol red-free DMEM containing 5\% (v/v) DCC-treated FBS, $4.5 \mathrm{~g} / \mathrm{liter}$ glucose, $2 \mathrm{mM}$ L-glutamine, $1 \mathrm{mM}$ sodium pyruvate, $50 \mu \mathrm{m} / \mathrm{ml}$ gentamicin, $30 \mathrm{nM}$ sodium selenite and $10 \mu \mathrm{g} / \mathrm{m}$ transferrin (all reagents from Life Technologies). Cells were seeded onto Chamber Slides ${ }^{\text {T3t }}$ (Nunc Inc. Naperville, IL, U.S.A.) at a concentration of 15.000 cells/chamber. Chamber $\$ 1$ des ${ }^{\text {ia }}$ had been coated with $50 \mu \mathrm{g} / \mathrm{ml}$ poly L-lysine one day before use. Cells were allowed to attach for $24 \mathrm{~h}$ and thereafter the medium was supplemented with growth factors, i.e. $10 \mathrm{\mu g} / \mathrm{m}$ l final concentration insulin (Life Technologies) and $5 \mathrm{ng} / \mathrm{m} /$ final concentration basic fibroblast growth factor (Life Technologies), retinoids (concentration ranging from $10^{11} \mathrm{M}$ to $10^{6} \mathrm{M}$ ) and liarozole-fumarate (concentration ranging from $10^{-7} \mathrm{M}$ to $10^{-5} \mathrm{M}$ ). Cells were grown under these conditions for 7 days with medium changes 3 and 6 days after seeding.

\section{Bromodeoxyuridine (BrdU) detection}

Cell proliferation was measured using BrdU incorporation, which is considered an accurate method because it is a direct assay of DNA synthesis (Dolbeare. 1995 .

After 7 days of culture with retinoids as described above, MCF-7 cells were labeled with $100 \mu \mathrm{M}$ Brd0 for $2.5 \mathrm{~h}$ and fixed. Incorporated BrdU was visualized by immunofluorescence staining using the 
Tyramide Signal Amplification (TSA)-Direct kit (Green) (DuPont NEN) as described in detall previously (Van heusden et al. 1997a).

The Brdu labeling index was defined as the proportion of BrdU-positive cells; representing cells in $S$. phase, and was estimated by counting cells under a huorescence microscope (Axiophot. Zeise. Germany) with a dual filter set for simultaneous visualization of fuorescein and propidium iodide signals. About 800 cells were counted twice for each test compound per experiment. Average results are presented as mean $\pm S D$ of three to five experiments.

\section{Microcolumn assay for ATRA catabolism}

ATRA catabolism was quantitatively determined using the microcolumn assay as described previously (Krekels et al. 1997). Brielly, cells cultured in medium containing 5\% DCC-treated FBS, were pretreated for $24 \mathrm{~h}$ with $10^{\circ} \mathrm{M}$ ATRA to induce the ATRA catabolic pathway (Wouters et al. 1992: Krekels et al. 1997). Cells were then washed with culture medium. harvested and resuspended at $4 \times 10^{6} \mathrm{cells} / \mathrm{ml}$. This cell suspension $(450 \mu l)$ was incubated for $90 \mathrm{~min}$ in the presence of $10^{-7} \mathrm{M}\left[11.12^{3} \mathrm{H}(\mathrm{N})\right]$ ATRA or $10^{-7} \mathrm{M}$ l $\left.^{3} \mathrm{G}\right] 9-\mathrm{cis}$-RA (Amersham Life Science. Buckinghamshire, United Kingdoml, and thereafter $2 \mathrm{ml} 100 \%$ acetonitrile was added. After centrifugation for $10 \mathrm{~min}$ at $780 \mathrm{~g}$ the resulting deproteinized supernatant was acidified with $2.5 \mathrm{ml} 40 \mathrm{mM}$ acetic acid and applied to a $3 \mathrm{ml} \mathrm{C18}$ Bond Elut LRC column (Varian, Harbor City. CA. U.S.A.; pretreated with $4 \mathrm{ml}$ distilled water) under a vacuum of $127 \mathrm{~mm}$ Hg using VAC ELUT SPS-24 and the effluent was collected. The column was eluted with $1 \mathrm{ml} 40 \%$ acetonitrile and the effluent was collected in the same vial. The collected effluent, containing the polar metabolites, was counted for radioactivity in a Packard Tri-carb 4530 liquid scintillation analyzer. Optiphase "Hi Safe II" (Wallac. Milton Keynes. United Kingdom) was used as a scintillator.

\section{HPLC analysis}

The MCF-7 cell suspension was prepared as described above and $450 \mu$, was incubated with $10^{\circ} \mathrm{M}[11$. 12. ${ }^{3}$ H(N)]ATRA or $10^{-7} \mathrm{M}\left[{ }^{3} \mathrm{H}\right] 9$-cis-RA for $4 \mathrm{~h}$. After centrifugation for $10 \mathrm{~min}$ at $780 \mathrm{~g}$. the supernatant was analyzed for the presence of ATRA metabolites and isomers.

Analysis of AIRA metabolites; Reverse-phase HPLC analysis was carried out on a Varian HPLC system consisting of a HPLC pump 9010, an autosampler 9095 and a diode array detector (Polyview 9065). The Star 4.0 data software (Varian) was used to analyze the chromatograms. Radioactivity in the eluate was monitored on-line by B-counting (Packard Radiomatic radioactivity monitor) using Utumaflo M (Packard. Meriden, CT, U.S.A.) as the scintillation solvent. The samples (150 $\mu$ ) were analyzed on a Zorbax $5 \mathrm{C} 8$ column $4.6 \mathrm{~mm}$ id. $x 250 \mathrm{~mm}, 5 \mu \mathrm{m}$; Chrompack. The mobile phase was methanol/ $2 \%$ acetic acid/acetonitrile (1.5:93:5.5) containing $40 \mathrm{mM}$ ammonium acetate (solwent $\mathrm{A}$ ). Solvent $\mathrm{B}$ consisted of methanol/2\% acetic acid/acetonitrile (1530:55) containing $40 \mathrm{mM}$ ammonium acetate and solvent $C$ was $100 \%$ methanol. A linear gradient at a flow rate of $1 \mathrm{ml} / \mathrm{min}$ was performed in 25 min from $24 \% \mathrm{~A}-76 \% \mathrm{~B}$ to $15 \% \mathrm{~A}-85 \% \mathrm{~B}$. The solvent was then changed to $50 \% \mathrm{~B}-50 \% \mathrm{C}$ in $15 \mathrm{~min}$. To elute unchanged ATRA the solvent was changed to $100 \% \mathrm{C}$ after $40 \mathrm{~min}$. 
Andysis of ATRA Isomers: For the separation of the isomers of ATRA the same HPLC equipment was used. Samples $(150 \mu \mathrm{ll})$ were analyzed on a Novapak column $39 \mathrm{~mm}$ i.d. $x 300 \mathrm{~mm}$ ). Solvent D was methanol/2\% acetic acid/acetonitrile (15:3055) containing $40 \mathrm{mM}$ ammonium acetate. Solvent $\mathrm{E}$ consisted of methanol/2\% acetic acid/acetonitrile (20:20:60) containing $40 \mathrm{mM}$ ammonium acetate and solvent $\mathrm{f}$ was $100 \%$ methanol. The mobile phase was $50 \% \mathrm{D}-50 \% \mathrm{E}$ for $30 \mathrm{~min}$ at a flow rate of 1 ml/min. Then a linear gradient was performed to $100 \% \mathrm{E}$.

\section{Statistical analysis}

Data were andyzed using the two-talled Mann-Whitney U-test using the Stat View II software (Abacus Concepts. Inc. Berkeley. CA. U.S.A.). Significance was defined at the level of ${ }^{*} p<.01$ and ${ }^{* *} p<.001$.

\section{Results}

Liarozole-fumarate potentiates the antiproliferative activity of ATRA and its catabolites, but not of its stereoisomers

MCF- 7 cells were cultured in steroid-and retinoid-free medium supplemented with growth factors. Under these culture conditions. MCF-7 cells showed a BrdU labeling index of $25.2 \pm 1.4 \%(n=5)$. Liarozole-fumarate alone had no effect on MCF-7 cell proliferation up to a concentration of $10^{-6} \mathrm{M}$ (Fig. 1a). At $10^{-5} \mathrm{M}$, liarozole-fumarate decreased the BrdU labeling index to $21.5 \pm 2.8 \%(n=4)$. In all following experiments liarozole-fumarate was therefore used at a concentration of $10^{6} \mathrm{M}$.

Liarozole-fumarate $\left(10^{-6} \mathrm{M}\right)$ significantly enhanced the antiproliferative activity of ATRA (Fig. 1b) and its naturally occurring catabolites 4-oxo-ATRA (Fig. IC) and 5.6-epoxy-ATRA (Fig. 1d) as reflected by a further decrease in the BrdU labeling index. This potentiation was more pronounced at lower retinoid concentrations. Note that liarozolefumarate was not able to enhance the antiproliferative activity at retinoid concentrations of $10^{6} \mathrm{M}$ (Figs, 1b, c, d). In the case of 5,6-epoxy-ATRA Iliarozole-fumarate was not able to enhance the antiproliferative activity at concentrations of $10^{-7} \mathrm{M}$ and $10^{-6} \mathrm{M}$ (Fig. $\mathbb{I d}$ ). Liarozole-fumarate $\left(10^{-6} \mathrm{M}\right)$ did not enhance the antiproliferative activity of the stereoisomers 9-cis-RA (Fig. 1e) and 13-cis-RA (Fig. 1f).

\section{6-Epoxy-ATRA competes with ATRA for ATRA catabolism}

MCF-7 cells, cultured in medium containing 5\% DCC-treated FBS, were pretreated for $24 \mathrm{~h}$ with $10^{6}$ M ATRA to induce ATRA catabolism (Wouters et al., 1992; Krekels et al., 1997). ATRA catabolism was measured using $10^{-7} \mathrm{M}\left[{ }^{3} \mathrm{H}\right]$ ATRA as substrate. As shown in Figure 2 . 

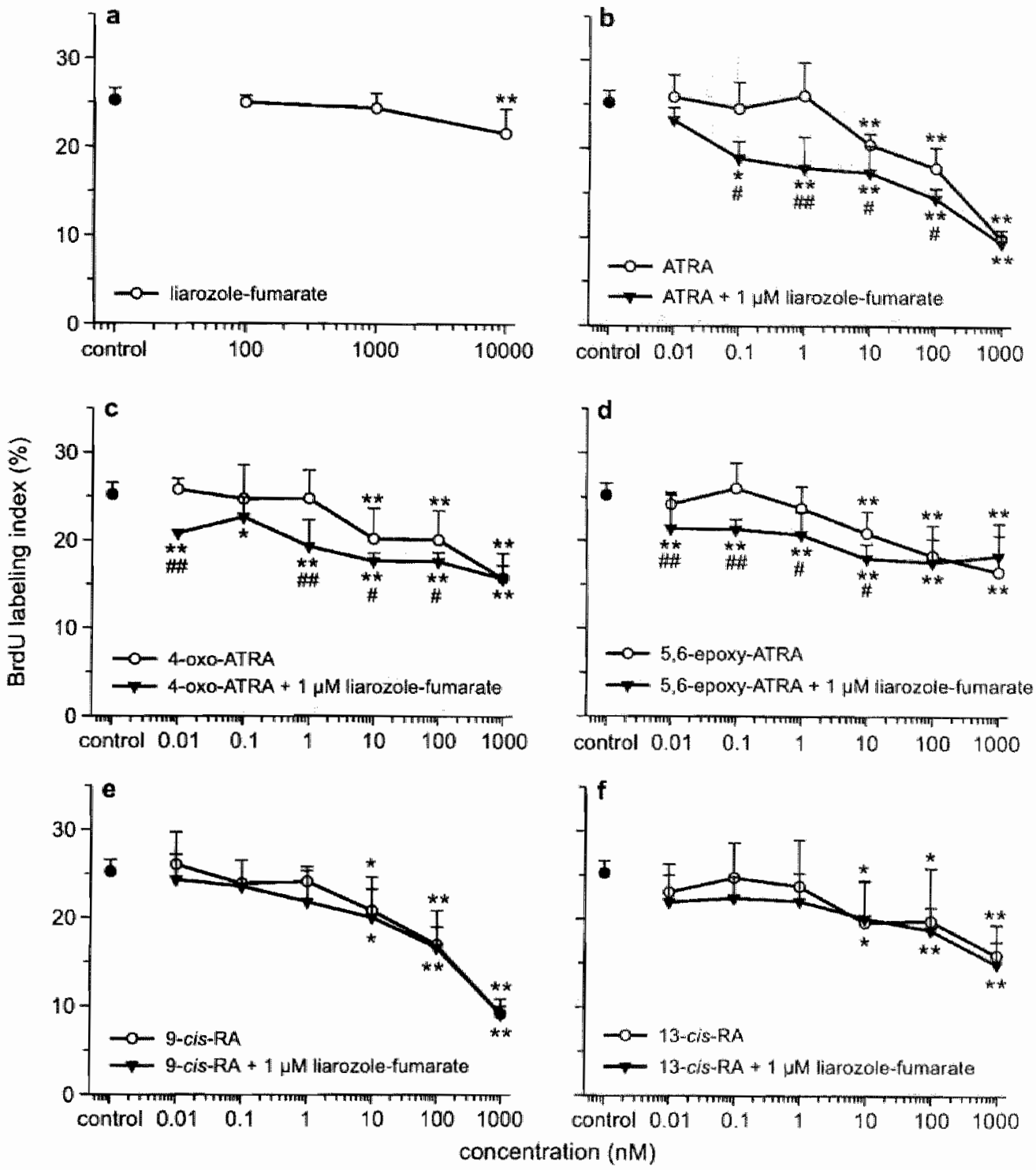

Figure I: Concentration-response curves showing the effect of liarozole-fumarate alone (a) or in combination with ATRA (b), 4-oxo-ATRA (c), 5,6-epoxy-ATRA (d), 9-cis-RA (e) and 13-cis-RA (II) in MCF-7 cells. Cells were cultured for 7 days in the presence of test compounds. Cell proliferation was measured by BrdU incorporation, as described in "Materials and Methods". Results are presented as mean \pm SD of three (b, e, f), four (a) or five $(c, d)$ experiments. " $p<.01$ and $p<.001$ wersus control cells (Mann-Whitney $U$ test). ${ }^{\#} p<.05$ and ${ }^{\# \#} p<.0 \|$ versus retinoid-treated cells (Mann-Whitney $U$-test). 


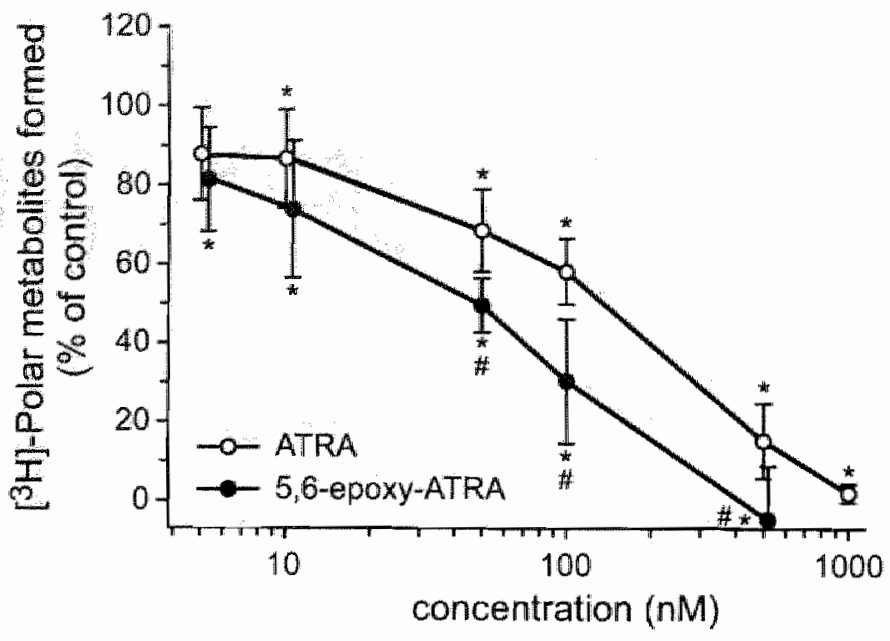

Figure 2: Competition between radioactive [ $\left.{ }^{3} \mathrm{H}\right] \mathrm{ATRA}$ and nonradioactive ATRA $\left(1 C_{50}=129 \pm 40 \mathrm{nM}\right)$ and 5,6 -epoxyATRA $\left(I C_{50}=50 \pm 28 \mathrm{nM}\right)$. MCF-7 cells were preincubated for $24 \mathrm{~h}$ with $10^{-6} \mathrm{M}$ ATRA to induce ATRA catabolism. Concentration-response curves for ATRA catabolism were determined using $10^{-7} \mathrm{M}\left[{ }^{3} \mathrm{H}\right]$ ATRA as substrate Results are presented as mean $\pm S D$ of five experiments. $p<.01$ versus control (Mann-Whitney $U$-test). ${ }^{*} p<.05$ versus ATRA treatment (Manm-Whitney $U$-test).

nonradioactive ATRA competed with [ $\left.{ }^{3} \mathrm{H}\right] \mathrm{ATRA}$ with an $\mathrm{IC}_{50}$ value of $129 \pm 40 \mathrm{nM}(n=5)$. 5.6-epoxy-ATRA was a better competitor than ATRA and decreased the amount of polar $\left[{ }^{3} \mathrm{H}\right]$ ATRA metabolites with an $\mathrm{IC}_{50}$ value of $50 \pm 28 \mathrm{nM}(n=5)$.

\section{Liarozole-fumarate inhibits the catabolism of ATRA}

Liarozole-fumarate concentration-dependently increased the level of unmetabolized [ $\left.{ }^{3} \mathrm{H}\right] \mathrm{ATRA}$ and concomitantly inhibited the formation of polar [ $\left.{ }^{3} \mathrm{H}\right]$ ATRA metabolites (Fig. 3. Table I). The unidentified apolar peak was concentration-dependently increased by liarozole-fumarate. The isomerization process of ATRA to 9-cis-RA and 13-cis-RA was not affected by liarozolefumarate (Table I). A peak co-eluting with 4-oxo-ATRA was formed to only a limited extent (data not shown). No peak co-eluting with authentic 5,6-epoxy-ATRA could be detected with or without treatment with liarozole.fumarate at concentrations from $10^{-6} \mathrm{M}$ to $10^{-5} \mathrm{M}$. 

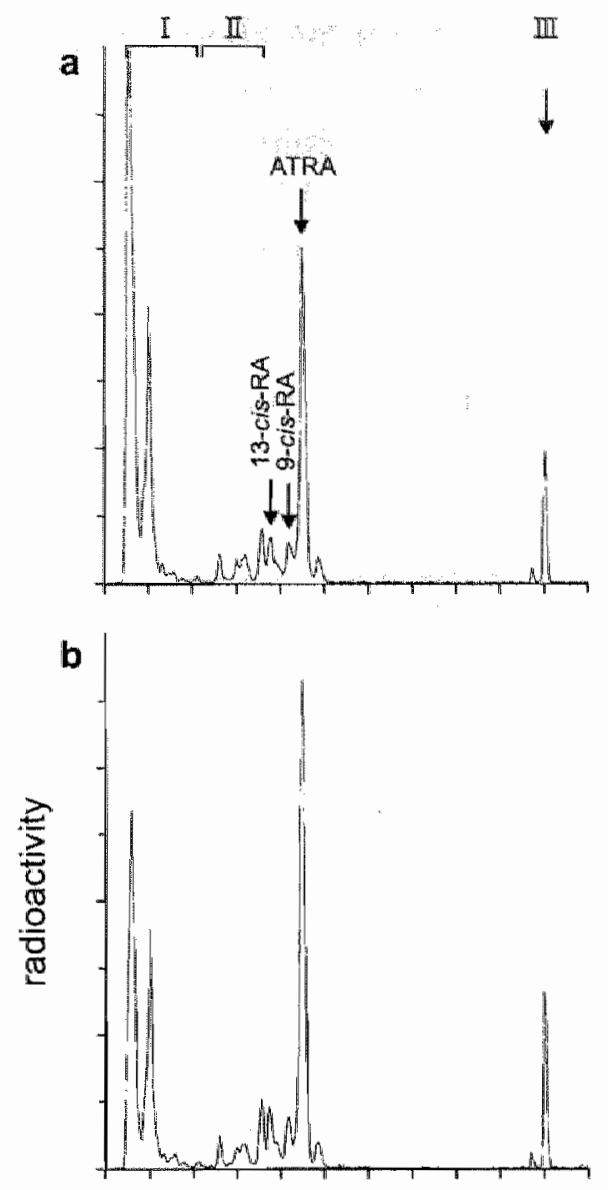

Figure 3: Chromatograms illustrating the metabolism of $\left.{ }^{3} \mathrm{H}\right]$ ATRA in the absence $(\mathrm{a})$ or presence of liarozole-fumarate at a concentration of $10^{-6} \mathrm{M}$ (b) or $10^{-5} \mathrm{M}$ (c). Cells were incubated for $24 \mathrm{~h}$ with $10^{-6} \mathrm{M}$ ATRA to induce ATRA catabolism, washed twice and collected. Cells were then incubated for $4 \mathrm{~h}$ with $\| 0^{-7} M\left[{ }^{3} \mathrm{H}\right]$ ATRA and the supernatant was analyzed by reverse phase HPLC. I: very pollar metabalites. II: intermediate polar metabolites. III: apolar metabolite.

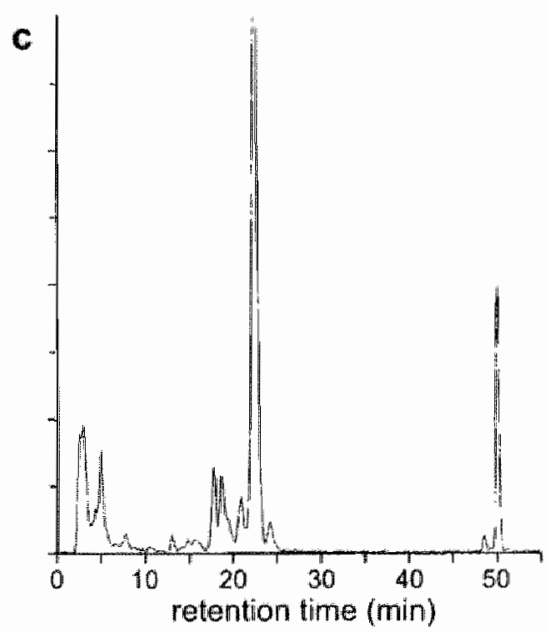


9-Cis-RA is not metabolized in MCF-7 cells

[ $\left.{ }^{3} \mathrm{H}\right]$-cis-RA was not converted to polar metabolites in MCF-7 cells as measured by HPLC analysis. Similar results were obtained by the microcolumn assay (data not shown). The metabolism of 13-cis-RA, 4-oxo-ATRA and 5.6-epoxy-ATRA could not be studied because these retinoids are not available as tritiated compounds and unlabeled retinoids could not be used for these purposes (data not shown: Gubler and Sherman, 1990)

Table I: Quantitative analysis of [ $\left.{ }^{3} H\right] A T R A$ metabolism in MCF-7 cells

\begin{tabular}{lccc}
\hline & \multicolumn{4}{c}{ Radioactivity $(\%)$} \\
\cline { 2 - 4 } HPLC peaks & control & $+10^{-6} \mathrm{M}$ liarozole & $+10^{-5}$ M liarozole \\
\hline RA(\%ATRA,9-cis-RA & 43 & 52 & 73 \\
and 13-cis-RA) & $(78,13,10)$ & $(78,13,10)$ & $(82,10,9)$ \\
Metabolites & 36 & & 10 \\
very polar & 15 & 28 & 5 \\
intermediately polar & 6 & 8 & 12 \\
apolar & & 12 & 12 \\
\hline
\end{tabular}

\section{Discussion}

The present study further elucidates the mechanism of action of liarozole-fumarate by showing its enhancing effect on the antiproliferative activity of naturally occurring ATRA catabolites. These effects could only be properly studied in a steroid- and retinoid-free culture medium supplemented with growth factors. We have previously demonstrated that not only ATRA itself, but also its naturally occurring catabolites, 4-oxo-ATRA and 5,6-epoxyATRA, as well as its stereoisomers, 9-cis-RA and 13-cis-RA. significantly inhibit the proliferation of MCF-7 human breast cancer cells (Van heusden et al.. 1997b). Liarozolefumarate, at a concentration of $10^{-6} \mathrm{M}$, enhanced the antiproliferative activity of ATRA and its catabolites, but not that of the stereoisomers of ATRA. As such liarozole-fumarate acts as a versatile inhibitor of the cytochrome P450-dependent ATRA catabolic pathway (Fig. 4). Liarozolle-fumarate $\left(10^{-6} \mathrm{M}\right)$ significantly enhanced the antiproliferative activity of ATRA in MCF-7 cells. This potentiating effect was more than 100-fold at low retinoid-concentrations $\left(10^{10} \mathrm{M}\right.$ to $\left.10^{9} \mathrm{M}\right)$ in contrast to the 10 -fold enhancement as previously demonstrated under growth conditions with culture medium containing untreated FBS (Wouters et al.. 1992; Van heusden et al., 1996). The effect of liarozole-fumarate on ATRA metabolism was analyzed 
by HLPC. Only the supernatant was studied. We have previously shown that in the cell extract the same overall metabolite profile can be found (Wouters et al, 1992). Liarozolefumarate increased the level of RA and concomitantly inhibited the formation of more polar metabolites in a concentration-dependent manner. Together, these findings suggest that liarozole-fumarate enhances the antiproliferative activity of ATRA by inhibiting its catabolism. in agreement with our previous findings (Wouters et al., 1992).

Liarozole-fumarate $\left(10^{-6} \mathrm{M}\right)$ enhanced the antiproliferative activity of the naturally occurring catabolite 4-oxo-ATRA, confirming that its catabolism is inhibited by liarozole-fumarate.<smiles>CC1=C(/C=C/C(C)=C/C=C/C(C)=C/C(=O)O)C(C)(C)CCC1</smiles>

13-cis-retinoic acid

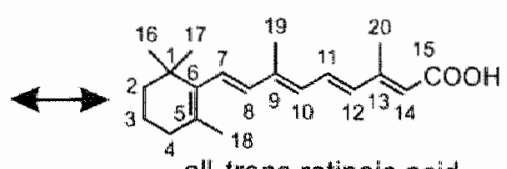
all-trans-retinoic acid

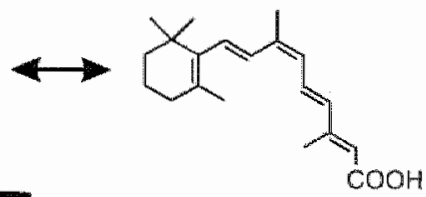

9-cis-retinoic acid<smiles>CC(/C=C/C12OC(C)(CCC1C)C2(C)C)=C\C=C\C(C)=C\C(=O)O</smiles>

5,6-epoxy-all-trans-retinoic acid

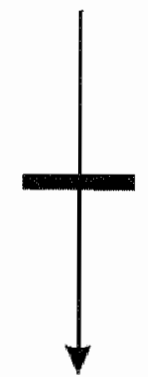

more polar metabolites

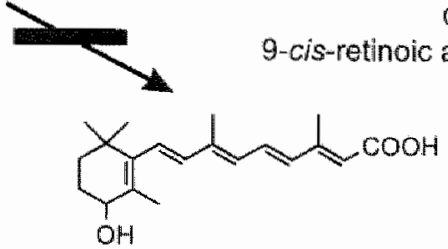

4-hydroxy-all-trans-retinoic acid<smiles>CC(C=CC=C(C)C=CC(C)=C1C(=O)CCC(C)=C1C)=CC=CC(=O)O</smiles>

4-oxo-all-transmretinoic acid

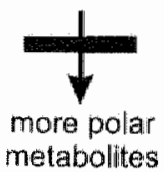

inhibition by liarozole-fumarate

Figure 4: Proposed mechanism of action of liarozole-fumarate. The drug acts as a versatile inhibitor at different steps of the ATRA catabolic pathway. Liarozole-fumarate not only inhibits the catabolism of ATRA, but also of its catabolites 4-oxo-ATRA and 5,6-epoxy-ATRA, thereby enhancing their antiproliferative activity. 
Indeed. Van Wawe et al: (1994) have shown that liarozole-fumarate inhibited the formation of more polar metabolites from 4-oxo-ATRA in hamster liver microsomes. In addition. liarozole-fumarate enhanced the plasma half-life of 4-oxo-ATRA in rats (Van Wauwe et al. 1994). Talken together, these findings suggest that catabolism of 4-oxo-ATRA involves at least one cytochrome P450-dependent enzyme (Roberts et al., 1980; Van Wauwe et al., 1994) that is inhibited by liarozole-fumarate.

The antiprolferative activity of 5.6-poxy-ATRA was also potentiated by liarozole-fumarate $\left(10^{-6} \mathrm{M}\right)$. One possible explanation for this synergism is that liarozole-fumarate inhibits the cytochrome P450-dependent catabolism of 5:6-epoxy-ATRA. Although such enzyme(s) are unknown, it is not unlikely that 5.6-epoxy-ATRA is metabolized by the same enzyme(s) as ATRA. since 5,6-epoxy-ATRA was a better competitor than ATRA itself in our assay for measuring ATRA catabolism. Although liarozole-fumarate was present at a tenfold higher concentration, i.e. $10^{-6} \mathrm{M}$, the drug was not able to enhance the antiproliferative activity of a higher concentration $\left(10^{-7} \mathrm{M}\right)$ of 5,6-epoxy-ATRA when tested at a concentration of $10^{7} \mathrm{M}$. These data support the hypothesis that both liarozole-fumarate and 5,6-epoxy-ATRA compete for the same enzyme(s) and that the higher affinity of 5.6-epoxy-ATRA for these enzyme(s) does not allow enhancement.

The ability of ATRA to isomerize in cell culture has been described before (Urbach and Rando, 1994). Liarozole-fumarate $\left(10^{-6} \mathrm{M}\right)$ had no effect on isomerization of ATRA. The antiproliferative activity of 9 -cis-RA and 13-cis-RA could not be enhanced by liarozole-fumarate $\left(10^{\circ} \mathrm{M}\right)$. In contrast, in tivo liarozole-fumarate has been shown to enhance plasma levels of 9-cis-RA (Achkar et al., 1994) and 13-cis-RA (Westarp et al, 1994). Since RA catabolism may be cell-specifically regulated. the most likely explanation for this discrepancy is the absence of cytochrome P450-dependent enzymes that catabolize 9-cis-RA and 13-cis-RA in MCF-7 cells. In favour of this hypothesis is our finding that 9-cis-RA was not converted to polar metabolites in these cultures. Although, we have previously shown that 9-cis-RA and 13-cisRA can isomerize to ATRA in MCF-7 cells (Krekels et al. 1997), the fact that their antiproliferative activity was not potentiated by liarozole-fumarate, indicates that their effect on MCF 7 cell proliferation was not due to conversion to ATRA.

We have shown that both 9-cis-RA and 13-cis-RA compete with ATRA in our assay for measuring ATRA catabolism in MCF-7 cells (Krekels et al. 1997). In this study, we show that liarozole-fumarate was not able to enhance the antiproliferative activity of these stereoisomers. Taken together, these findings suggest that although both stereoisomers are able to bind to ATRA catabolizing enzyme(s), they are not used as subtrates by these enzyme(s) 
because then an enhancing effect by liarozole-fumarate would be expected. These latter data are in agreement with the observations of Duell et al. (1996) in mouse skin.

In conclusion, we can state that liarozole-fumarate is not only able to inhibit the catabolism of ATRA, but also that of 4-oxo-ATRA and 5.6-epoxy-ATRA, thereby enhancing their antiproliferative activity. Liarozole-fumarate does not enhance the antiproliferative activity of the stereoisomers 9-cis-RA and 13-cis-RA in MCF-7 human breast cancer cells, most probably due to the absence of their oxidative catabolism in these cells. Together, these findings extend and confirm the hypothesis that liarozole-fumarate acts as a versatile inhibitor in the ATRA catabolic pathway (Fig. 4). and may show potential in circumvention of RA resistance in cancer.

\section{Acknowledgements}

We sincerely thank Dr. J. Van Wauwe for his critical review of the manuscript. We are very grateful to Dr. M. Klaus (Hoffmann-La-Roche, Basel. Switzerland) for the generous gift of the retinoids. The technical assistance of Hélène Bruwiere and Willy Cools is highly appreciated. The photographic layout by Lambert Leijssen and colleagues is also acknowledged.

\section{References}

Acevedo P., and Bertram, J.S. Liarozolle potentiates the cancer chemopreventive activity of and the up-regulation of gap junctional communication and connexin 43 expression by retinotc acid and B-carotene in 10 T1/2 cells. Carcinogenesis 16:2215-2222, 1995.

Achkar, C.C., Bentel, J.M., Boylan, J.F, Scher, H.I. Gudas, L.J., and Miller, W.H.Jr. Differences in the pharmacokinetic properties of orally adminustered all-rrans-retinoic acid and 9-cis-retinoic acid in the plasma of nude mice. Drug Metab. Dispos. 22: 451-458. 1994.

Barua, A.B., Gunning, D.B., and Olson. I.A. Metabolism in vivo of all-trans- 11 - $\left.^{3} \mathrm{H}\right]$ retinoic actd after an oral dose in rats. Biochem. 1. 277: 527.531, 1991.

De Coster, R., Wouters, W. Van Ginckel R. End, D., Krekels, M., Coene, M.-C., and Bowden, C. Experimental studies with liarozole ( $R$ 75251): an antitumoral agent which inhibits retinoic acid breakdown. J. Steroid Biochem. Mol. Biol. 43; 197-201. 1992. 
Dijkman, G.A., Van Moortselaar, R.J.A. Van Ginckel, R., Van Stratum, P., Wouters, L., Debruyne, E.M.J., Schalken. J.A., and De Coster. $R$. Antitumoral effects of liarozole in androgen-dependent and independent B3327-Dunning prostate adenocarcinomas. J. Urol. 151: 217-222. 1994.

Dolbeare. F. Bromodeoxyuridine: a diagnostic tool in biology and medicine. Part I: Historical perspectives. histochemical methods and cell kinetics. Histochem. I. 27: 339-369, 1995.

Duell, E.A., Kang, S., and Voorhees, J.J. Retinoic acid isomers applied to human skin in vivo each induce a 4hydroxylase that inactivates only trans-retinoic acid. I. Invest. Dermatol. 106: 316320,1996

Frolik, C.A. Roberts, A.B. Tavela, T.E., Roller, P.P., Newton, D.L., and Sporn, M.B. Isolation and identification of 4hydroxy-and 4-oxo-retimoic acid. In vitro metabolites of all-trans-retinoic acid in hamster trachea and liver. Biochemistry 18: 2092-2097, 1979.

Gubler. M.Lu, and Sherman, M.I. Metabolism of retinoic acid and retinol by intact cells and cell extracts. Methods Enzymol. 189: 525-530, 1990.

Hall, A.K. Liarozole amplifies retinoid-induced apoptosis in human prostate cancer cells. Anti-Cancer Drugs 7: 312-320, 1996.

Hong, W.K, and Itri. L.M. Retinoids and human cancer. In: Sporn, M.B., Roberts, A.B., Goodman. D.S. (eds.), The Retinoids. Biology, Chemistry and Medicine. Ed. 2. pp. 597-630. New York: Raven Press, Ltd., 1994.

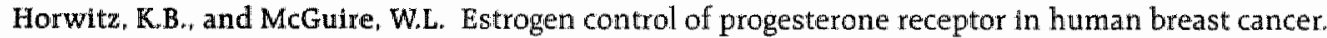
). Biol. Chem. 253: 2223-2228, 1978 .

Kizaki ${ }^{\text {M., Jeno }}$ H., Yamazoe, Y. Shimada, M., Takayama, N., Muto, A., Matsushita, H., Nakajima, H., Morikawa, M., Koefflex, H.P., and Ikeda, X. Mechanisms of retinoid resistance in leukemic cells: possible role of cytachrome P450 and P-glycopratein. Blood 87: 725-733, 1996.

Krekels, M.D.W.G.,Zinmerman, I., Janssens, B., Van Ginckel, R., Cools, W., Van Hove, C., Coene, M.C. and Wouters, W. Analysis of the oxidative catabolism of retinoic acid in rat Dunning R3327G prostate tumors. Prostate 29:36-41, 1996.

Krekels, M.D.W.G. Verhoeven, A., van Dun. J., Cools, W., Van Hove, C., Dillen, L., Coene, M,-C., and Wouters, W. Induction of the oxidative catabolism of retinoic acid in MCF-7 cells. Br. J. Cancer 75: 1098.1104. 1997

Lotan. R. Effects of vitamin A and its analogs (retinoids) on normal and neoplastic cells. Biochim. Biophys. Acta 605: 33-91, 1980.

Mahler, $\mathrm{C}$, Verhelst, J., and Denis. $\mathrm{L}$. Ketoconazole and liarozole in the treatment of advanced prostatic cancer. Cancer 71 (suppl): 1068-1073. 1993. 
McCormick, A.M. Napoli, J.L., Schnoes, H.K. and DeLuca, H.F. Isolation and identilication of 5.6. epaxy-retinoic acid: A biologically active metabolite of retinoic acid. Biochemistry 17:40854090. 1978.

Moon, R.C., Mehta, R.G., and Rao, KV.N. Retinoids and cancer in experimental animals. Im: Sporn. M.B.. Roberts. A.B.. Goodman. D.S. (eds.). The Retinoids. Biology, Chemistry and Medicine, Ed. 2. pp. 573-595. New York: Raven Press, Ltd. 1994.

Muindi, J.R.F., Frankel, S.R. Miller, W.H.Jr. Jakubowski, A., Scheinberg, D.A., Young, C.W. Dmitrovsky, E., and Warrell, R.P.I. Continuous treatment with all-trans-retinoic acid causes a progressive reduction in plasma drug concentrations: implications for relapse and retinoid "resistance" in patients with acute promyelocytic leukemia. Blood 79: 299-303, 1992.

Roberts, A.B., Lamb, L.C., and Sporn, M.B. Metabolism of all-trans-retinoic acid in hamster liver microsomes: oxidation of 4-hydroxy- to 4-keto-retinoic acid. Arch Biochem. Biophys. 199: 374 383.1980.

Smets, G., Van Ginckel, R., Daneels. G., Moeremans. M., Van Wauwe, J, Coene, M.-C., Ramaekers F.C.S., Schalken, J.A. Borgers, M., and De Coster, R. Liarozole, an antitumor drug, modulates cytokeratin expression in the Dunning AT-6sq prostatic carcinoma through in situ accumulation of all-trans-retinoic acid. Prostate 27: 129-140, 1995.

Smith, M.A., Adamson, P.C., Balis, F.M.. Feusner. Jo, Aronson, L., Murphy, R.F., Horowitz, M.En, Reaman, G., Hammond, G.D., Fenton, R.M., Connaghan, G.D. Hittelman, W.N., and Poplack, D.G. Phase I and pharmacokinetic evaluation of all-trans-retinoic acid in pediatric patients with cancer. I. Clin. Oncol. 10: 1666-1673. 1992.

Stearns, M.E., Wang, M., and Fudge, K. Liarozole and 13-cis-retinoic acid anti-prostatic tumor activity. Cancer Res. 53: 3073-3077, 1993.

Urbach, J., and Rando, R.R. Isomerization of all-trans-retinoic acid to 9-cis-retinoic acid. Biochem. J. 299: 459-465. 1994 .

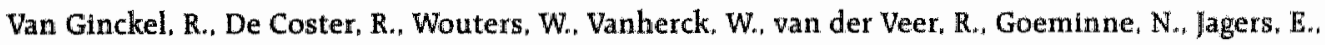
Van Cauteren, H. Wouters. L., Distelmans "W., and Janssen, PA.]. Antitumoral effects of R75251 on the growth of transplantable $\mathrm{R} 3327$ prostatic adenocarcinoma in rats. Prostate $16: 313-323$. 1990.

Van heusden, J., Borgers, M., Ramaekers, F, Xhonneux. B., Wouters, W. De Coster, R., and Smets, G. Liarozole potentiates the all-rrans-retinoic acid-induced structurall remodelling in human breast carcinoma MCF-7 cells in vitro. Eur. J. Cell Biol. 71: 89-98, 1996.

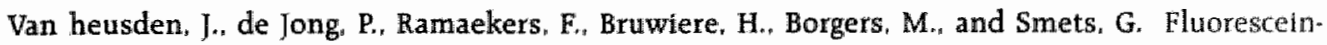
labeled tyramide strongly enhances the detection of low bromodeoxyuridine incorporation levels. J. Histochem. Cytochem, 45: 315-319, 1997a. 


\section{Chapter 6}

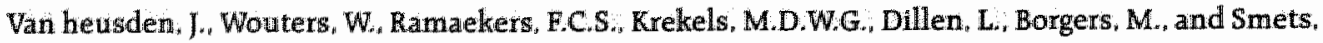
G. All-trans-retinoic acid metabolites significantly inhibit the proliferation of MCF-7 human breast cancer cells in vitro. Br. J. Cancer. in press. 19976 .

Van Wauwe, J.P., Coene; M.-C., Goosens. J., Cools, W., and Monbaliu, J. Effects of cytochrome P450 inhibitors on the in wiwo metabolism of all-trans-retinotc acid in rats. J. Pharmacol. Exp. Ther. 252: $365-369.1990$.

Van Wauwe, J., Van Nyen, G., Coene, M.-C., Stoppie, P., Cools; W., Goossens, J., Borghgraef, P., and Janssen, $\mathrm{P}$. Liarozole, an inhibitor of retinoic acid metabolism. exerts retinold-mimetic effects in vivo. J. Pharmacol. Exp. Ther. 261: 773-779. 1991.

Van Wauwe, J., Coene, M.-C., Cools, W. Goosens, J., Lauwers. W., Le Jeune. L., Van Hove, C., and Van Nyen, G. Liarozole furmarate inhibits the metabolism of 4-keto-all-trans-retinoic acid. Biochem. Pharmacoll, 47: 737-741, 1994.

Warrell, R.P.Jr. Retinoid resistance in acute promyelocytic leukemia: new mechanisms, strategies. and implications. Blood 82: 1949-1953, 1993.

Warrell, R.P.Jr., de The. H., Wang, Z.Y, and Degos, L. Acute promyelocytic leukemia. N. Engl. J. Med. 329: 177-189, 1993.

Westarp, M.E., Westarp, M.P., Bollag, Wo Bruynseels, J., Biesalski, H., Grossmann, N., Kornhuber H.- $^{\circ}$ H. Effect of six retinoids and retinoic acid catabolic inhibitor liarozole on two glioblastoma cell lines, and in vivo experience in malignant brain tumor patients. In: Banzet, P. Holland, J.F., Khayat. D. Weil. M. (eds.), Cancer Treatment - An update, pp. 590-598. Paris: Springer, 1994.

White, J.A., Guo, Y.-D., Baetz, K., Beckett-Jones, B., Bonasoro, J., Hsu, K.E., Dilworth, F.J., Jones, G., and Petkovich, M. Identification of the retinoic acid-inducible all-trans-retinoic acid 4-hydroxylase. J. Biol. Chem. 271: 29922-29927. 1996.

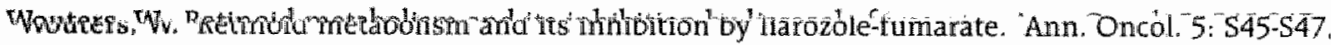
1.994.

Wouters, W. van Dun, J.. Dillen, A. Coene, M.-C."Cools, W., and De Coster, R. Effects of liarozole, a new antitumor compound, on retinoic acid-induced inhibition of cell growth and on retinoic acid metabolism in MCF-7 human breast cancer cells. Cancer Res. 52: 2841-2846, 1992. 



\section{General discussion}

Retinoids are well-known to inhibit cell proliferation and to induce differentiation of cancer cells. The most active naturally occurring retinoid is believed to be all-trans-retinoic acid (ATRA), Cancer therapy with ATRA so far has met with limited success and has been significantly hampered by toxicity and the prompt emergence of ATRA resistance. Inhibitors of ATRA catabolism might therefore prove valuable to circumvent these problems.

\section{Catabolism of ATRA represents an inactivation pathway.}

ATRA catabolism was originally believed to convert ATRA into degradation products without biological activity (Frolik et al., 1979; Sietsema and De Luca. 1982: Silva et al., 1987). More recently it was shown that ATRA catabolites, including 4-oxo-ATRA and 5.6-epoxy-ATRA, have significant biological activity in a number of growth and differentiation assays, but their activity was always less than that of ATRA (Williams et al., 1987; Pijnappel et al., 1993: Reynolds et al. 1993: Ramp et al. 1994). Furthermore, in another system 4-oxo-ATRA was shown to be more potent than ATRA. suggesting that ATRA catabolites can fulfill a specific role in ATRA signalling. Indeed, in early Xenopus laevis embryos 4-oxo-ATRA was shown to be a highly active modulator of positional specification and to be a potent inducer of the expression of Hox genes in these embryos (Pijnappel et al.. 1993). In addition. Takatsuka et al. (1996) suggested that a metabolite of ATRA rather than ATRA itself was responsible for the observed growth inhibition in human breast cancer cells. We investigated the latter hypothesis and our data suggest that ATRA itself, and not one of its metabolites, is responsible for the observed growth inhibition in MCF-7 (Chapter 5). This hypothesis was further 
supported by showing that the antiproliferative activity of ATRA could be enhanced while its catabolism was blocked by an inhibitor (Chapter 6). In agreement with our findings, van der Leede et al. (1997) clearly demonstrated that catabolism of ATRA is not required to inhibit growth of human breast cancer cells.

In the context of this present knowledge, we hypothesize that ATRA catabolism is essentially an inactivation pathway, and that the intermediates formed in this pathway have a significant biological activity, but less than that of ATRA. This hypothesis does not exclude the possibility that in some models ATRA catabolites can contribute to the observed effects of ATRA. depending on the balance between their formation and further breakdown. The apparent contradiction that in some models ATRA catabolites are as active (Chapter 5: Gratas et al. 1993: Nikawa et al., 1995; Gaemers et al., 1996) or even more active (Pijnappel et al.. 1993) than the parent compound ATRA, are most likely to be explained by possible differences in uptake i metabolism and transport to the nucleus.

\section{Liarozole-fumarate: a versatile inhibitor of ATRA catabolism}

Since ATRA is inactivated via catabolism, compounds that are able to inhibit this breakdown would be expected to enhance the biological activity of ATRA. Indeed, liarozole-fumarate has been shown to enhance the antiproliferative activity of ATRA (Wouters et al., 1992: Chapter 2 and 6). Besides, we showed that liarozole-fumarate also enhances the differentiation-inducing activity of ATRA (Chapter 2 and 3). In MCF-7 human breast cancer cells, liarozole-fumarate enhanced the ATRA-induced structural remodelling (Chapter 2). However, since differentiation of MCF-7 cells is not well defined. F9 mouse teratocarcinoma cells, as yet one of the best documented in witro models for biochemical and morphological ATRA-linked differentiation, were used to study the effect of liarozole-fumarate. In Chapter 3 it is shown that liarozole-fumarate potentiates ATRA-induced differentiation in F9 cells. as monitored by well-defined differentiation parameters. Whether these in witro findings can be extrapolated to the in vivo situation remains to be established.

Although liarozole-fumarate has been shown to inhibit ATRA catabolism (Van Wauwe et al. 1990: Wouters et al. 1992: Chapter 3 and 6), its molecular target(s) is/are unknown. Cytochrome P450-dependent enzymes are believed to play a key role in ATRA catabolism (Chapter 1). The finding that imidazole-containing compounds, such as for example liarozolefumarate, inhibit ATRA catabolism (Van Wauwe et al., 1990; Wouters et al. 1992), is consistent with this idea because imidazoles are well-known inhibitors of cytochrome P450-dependent 
enzymes (Halpert, 1995). The recent cloning of a zebrafish cytochrome 4450 -dependent enzyme, that catalyzed the 4 hydroxylation of ATRA, was the first molecular proot that cytochrome P450-dependent enzymes are indeed involved in ATRA catabolism (White et al. 1996). It would be interesting to investigate whether liarozole-fumarate is able to bind and inhibit the human counterpart of this ATRA 4-hydroxylase. Furthermore, the fact that liarozole-fumarate acts as a versatile inhibitor of ATRA catabolism (Chapter 6), suggests that cytochrome P450-dependent enzymes are also involved at other steps in the ATRA catabolic pathway. It remains to be established if these different steps are catalyzed by different enzymes.

\section{Inhibitors of ATRA catabolism as anticancer drugs}

ATRA has been proven to be active in the prevention and therapy of certain preneoplastic and neoplastic lesions (Bollag, 1995). However, clinical success with ATRA treatment has been limited. The main reasons that hamper the successfull clinical use of ATRA are its limited efficacy, toxicity, and the prompt emergence of ATRA resistance. These clinical drawbacks could be circumvented by the use of inhibitors of ATRA catabolism.

\section{Limited efficacy}

Limited efficacy of exogenous administered ATRA in a number of cancers can be explained by an insufficient uptake of ATRA into the tumor. This hypothesis is sustained by the finding that uptake of ATRA from plasma is strongly tissue-dependent. The underlying molecular mechanisms of ATRA uptake are unknown (Pfahl and Chytil, 1996), but some tissues, e.g. testis and kidney, have indeed been shown to take up very little ATRA from plasma (Kurlandsky et al. 1995). On the other hand, insensitivity to ATRA therapy can also be explained by an impairment at the level of nuclear receptors (van der Leede et al. 1995: Li et al. 1995; Seewaldt et al. 1995. Liu et al., 1996) or the presence of a constitutive tumor ATRA catabolism (Krekels et al., 1996). In the latter case, inhibitors of ATRA catabolism might prove valuable by increasing the level of ATRA inside the tumor itself. That this hypothesis is not merely speculative is shown by the finding that liarozole-fumarate enhances the level of ATRA both in plasma and in tissue (Van Wauwe et al. 1992; Smets et al., 1995).

\section{Toxicity}

For therapy, high doses of exogenous administered ATRA are required, that give rise to toxic side effects. The limited success of ATRA therapy might thus in part be explained by the 


\section{Chapter 7}

fact that the toxicity of high doses of ATRA limits the maximal achievable dose in vivo that is needed to exert a therapeutic effect. The use of inhibitors of ATRA catabolism. that are able to enhance endogenous levels of ATRA, cannot totally circumvent this problem as shown by signs of hypervitaminosis A in prostate cancer patients. However, it is possible that by increasing local, ie. tumor. ATRA levels, systemic ATRA levels remain lower as compared to that after exogenous ATRA administration, thereby minimizing the toxic side effects.

\section{ATRA resistance}

Another problem that has hampered the clinical use of ATRA is the prompt emergence of ATRA resistance. This phenomenon has not only been observed in APL patients (Castaigne et al., 1990: Warrell et al., 1993: Lazzarino et al., 1996), but also in patients with solid tumors (Lee et al., 1993; Muindi et al., 1994).

The exact molecular mechanisms behind the emergence of ATRA resistance remain to be elucidated. Proposed explanations include the increased expression of CRABPs, that can sequester ATRA and reduce its concentration in the nucleus (Kósa et al. . 1995: Widschwendter et al. 1995: Warrell, 1993; Boylan and Gudas. 1991; Cornic et al. 1992; Adamson et al., 1993). and the increased expression of multidrug-resistance genes (Kizaki et al., 1996). However, at present the most favoured explanation is that ATRA resistance emerges by the autoinduction of enzymes that increase its catabolism. Numerous findings are consistent with this view and suggest indeed that ATRA induces its own catabolism (McPhillips et al., 1987; Muindi et al. 1992a, 1992b. 1994: Smith et al., 1992; Rigas et al., 1993). If this latter hypothesis is true, inhibitors of ATRA catabolism might circumvent the problem of ATRA resistance.

\section{Conclusions and perspectives}

ATRA catabolism plays an important role in the inactivation of ATRA. However, the enzymes that are involved in this catabolic pathway and the molecular mechanisms that control cellspecific catabolism largely remain to be discovered.

Liarozole-fumarate is a versatile inhibitor of ATRA catabolism and enhances the antiproliferative as well as the differentiation-inducing activity of ATRA.

It remains to be established whether inhibitors of ATRA catabolism, such as liarozolefumarate, will prove valuable for non-palliative treatment, thereby opening a new era in differentiation therapy. 


\section{References}

Adamson, P.C., Boylan, J.F. Ballis, F.M., Murphy, R.F, Godwin K.A., Gudas L.J., and Poplack, D.G. Time course of induction of metabolism of all-trans-retinoic acid and the up-regulation of cellular retinoic acid-binding protein (CRABP). Cancer Res. 53: 472-476, 1993.

Bollag. W. Retinoids and interferon $\alpha$ in the prevention and treatment of preneoplastic and neoplastic diseases: a review. Retínoids Today Tomorrow 40: 26-31, 1995.

Boylan, J.F., and Gudas, L.J. Overexpression of the cellular retinoic acid binding protein-I (CRABP-I) results in a reduction in differentiation-specific gene expression in F9 teratocarcinoma cells. ). Cell. Biol. 112: 965-979, 1991.

Castaigne, S., Chomuienne, C. Daniel, M.T., Balleríni, P., Berger, R., Fenaux, P., and Degos, L. Alltrans-retinoic acid as a differentiation therapy for acute promyelocytic leukemia. I. Clinical results. Blood 76: 1704-1709. 1990.

Cornic, M., Delva, L., Guidez, F., Balitrand, N., Degos, L., and Chomienne, C. Induction of retinoic acid-binding protein in normal and malignant human myeloid cells by retinoic acid in acute promyelocytic leukemia patients. Cancer Res. 52: 3329-3334, 1992.

Frolik, C.A., Roberts, A.B.. Tavela, T.E., Roller, R.P., Newton, D.L." and Sporn, M.B. Isolation and identification of 4-hydroxy- and 4-oxo-retinoic acid. In vitro metabolites of all-trans-retinoic actd in hamster trachea and liver. Biochemistry 18: 2092-2097, 1979.

Gaemers, I.C., van Pelt, A.M.M., van der Saag, P.T., and de Rooij, D.G. All-trans-4-oxo-retinoic acid: a potent inducer of in wiwo proliferation of growth-arrested A spermatogonia in the vitamin A. deficient mouse testis. Endocrinology 137: 479-485, 1996.

Gratas, C., Menot, M.L., Dresch, C., and Chomienne, C. Retinoic acid supports granulocytic but not erythroid differentiation of myeloid progenitors in normal bone marrow cells. Leukemia 7 : 1.1.56-1162, 1993

Halpert, J.R. Structural basis of selective cytochrome P450 inhibition. Annu. Rev. Pharmacol Toxicol. 35: 29-53. 1995.

Kizaki, M., Ueno, H., Yamazoe, Y., Shimada, M. "Takayama, N., Muto, A., Matsushita. H. Nakafima. H., Morikawa, M., Koeffler, H.P., and Ikeda, Y. Mechanisms of retinoid resistance in leukemic cells: possible rolle of cytochrome P450 and P-glycoprotein. Blood 87: 725-733. 1996.

Kösa, K. Jones, C.S., and De Luca, L.M. The H-ras oncogene interferes with retinoic acid signaling and metabolism in NIH3T3 cells. Cancer Res. 55: 4850-4854, 1995.

Rrekels, M.D.W.G., Zimmerman, J., Janssens, B., Van Ginckel, R., Cools, W., Van Hove, C., Coene, M.C., and Wouters. W. Analysis of the oxidative catabolism of retinoic acid in rat Dunning R3327G prostate tumors. Prostate 29: 36-41, 1996. 
Kurlandsky, S.B. Gamble, M.V. Ramakrishnan. R, and Blaner. W.S. Plasma delivery of retinoic acid to tissues in the rat. J. Biol, Chem. 270: 17850-17857. 1995.

Lazzarino, M., Regazzi, M.B., and Corso, A. Clinical relevance of all-trans retinoic acid pharmacokinetics and its modulation in acute promyelocytic leukemia. Leukemia and Lymphoma 23: 539-543. 1996.

Lee. J.S., Newman, R.A. Lippman, S.M., Huber, M.H., Minor, T., Raber, M.N., Krakoff, LH. and Kong, W.K. Phase l evaluation of all-trans-retinoic acid in adults with solid tumors. J. Clin. Oncol. 11 : 959-966. 1993.

Li, X.S., Shao, Z,-M., Sheikh. M.S., Eiseman, J.L., Sentz, D. Jetten. A.M. Chen, J.C., Dawson, M.I., Aisner, S., Rishi, A.K., Gutierrez, P. Schnapper, L., and Fontana, J.A. Retinoic acid nuclear receptor $B$ inhibits breast carcinoma anchorage independent growth. J. Cell. Physiol. 165: 449-458, 1995.

Liu, Y., Lee, M.O. Wang, H.G., Li, Y., Hashimoto, Y. Klaus, M., Reed, I.C., and Zhang, X. Retinoic acid receptor $B$ mediates the growth-inhibitory effect of retinoic acid by promoting apoptosis in human breast cancer cells. Mol. Cell. Biol. 16: 1138-1149. 1996.

MCPhillips, M.D., Kallin, J.R. and Hill, D.L. The pharmacokinetics of all-trans retinoic acid and N-(2hydroxyethyl) retinamide in mice as determined with a sensitive and convenient procedure. Drug Metab. Dispos. 15: 207-211, 1987.

Muindi, J., Frankel, S.R., Huselton, C., DeGrazia, F., Garland, W.A., Young, C.W., and Warrell, R.P. Jr. Clinical pharmacology of oral all-trans-retinoic acid in patients with acute promyelocytic leulemia. Cancer Res. 52: 2138-2142, 1992a.

Muindi, J.. Frankel, S.R., Miller. W.H.Jr., Jakubowski, A. Scheinberg, D.A., Young, C.W., Dmitrovsky. E., and Warrell, R.P. Jr. Continuous treatment with all-trans-retinoic acid causes a progressive reduction in plasma drug concentrations: implications for relapse and retinoid "resistance" in patients with acute promyelocytic leukemia. Blood 79: 299-303, 1992b.

Muindi, J.F., Scher, H.I. Rigas, J.R., Warrell, R.P. Jr., and Young, C.W. Elevated plasma lipid peroxide content correlates with rapid plasma clearance of all-trans-retinoic acid in patients with advanced cancer. Cancer Res. 54: 2125 2128, 1994

Nikawa, T., Shulz, W.A. van den Brink, C.E., Hanusch, M., van der Saag, P., Stahl, W., and Sies, H. Efficacy of all-mars-B-carotene, canthaxanthin, and all-irans-" 9 -cis-, and 4-oxo-retinoic acids in inducing differentiation of an F9 embryonal carcinoma RARB-lacZ reporter cell line. Arch. Biochem. Biophys. 316: 665-672. 1995.

Pfahl, M., and Chytil. F. Regulation of metabolism by retinoic acid and its nuclear receptors. Annu. Rev. Nutr. 16: 257-283, 1996. 
Pijnappel, WW.M. Hendriks, H.F.,. Folkers, G.E., van den Brink, C.E. Dekker, E.J. Edelenbosch, C., van der Saag. P.T., and Durston. A.J. The retinoid ligand 4-oxo-retinolic acid is a highly active modulator of positional specification. Nature (London) 366: 340.344. 1993.

Ramp, U., Gerharz, C.D. Eifler. E., Biesalski, H.K, and Gabbert, H. E. Effects of retinoic acid metabolites on proliferation and differentiation of the clonal rhabdomyosarcoma cell line BA-HAN-IC. Biol. Cell $81: 31-37.1994$

Reynolds, N.J., Fisher, G.J., Griffiths, C.E.M., Tavakkol, A., Talwar, H.S., Rowse, P.E., Hamilton, T.A., and Voorhees. J.]. Retinoic acid metabolites exhibit biological activity in human keratinocytes, mouse melanoma cells and hairless mouse skin in vivo. J. Pharmacol. Exp. Ther. 266: 16361642, 1993 .

Rigas, J.R., Francis, P.A. Muindi, J.F., Kris, M.G. Huselton, C., DeGrazia, F, Orazem, J.P., Young, C.W., and Warrell, R.P.Jr. Constitutive variabillity in the pharmacokinetics of the natural retinoid, alltrans-retinoic acid, and its modulation by ketoconazole. J. Natl. Cancer Inst. 85: 1921-1926. 1993.

Seewaldt, V.L., Johnson, B. S., Parker, M.B., Collins, S.J, and Swisshelm. K. Expression of retinoic acid receptor $B$ mediates retinoic acid-induced growth arrest and apoptosis in breast cancer cells. Cell Growth Differ. 6: 1077-1088, 1995.

Sietsema, W.K., and DeLuca, H.F. Retinoic acid 5.6-epoxidase. J. Biol. Chem. 257: 4265-4270. 1982.

Silva, D.P., Valliere, C.R., and DeLuca, H.F. Lack of biological activity of physiological metabolites of all-trans-retinoic acid on vaginal epithelial differentiation. Arch. Biochem. Biophys. 259: 391$401,1987$.

Smets, G., Van Ginckel, R., Daneels. G., Moeremans, M., Van Wauwe, J., Coene, M.-C., Ramaekers, F.C.S., Schalken, J.A., Borgers, M.n and De Coster, R. Liarozole, an antitumor drug, modulates cytokeratin expression in the Dunning AT-6sq prostatic carcinoma through in situ accumulation of all-trans-retinoic acid. Prostate 27: 129-140, 1995.

Smith, M.A., Adamson, P.C., Balis, F.M., Feusner, J., Aronson, L., Murphy, R.F. Horowitz, M.E., Reaman, G., Hammond, G.D., Fenton. R.M., Connaghan, G.D., Hittelman, W.N., and Poplack, D.G. Phase I and pharmacokinetic evaluation of all-trans-rettnoic acid in pediatric patients with cancer. J. Clin. Oncol. 10: 1666-1673. 1992.

Takatsuka, J., Takahashi. N.n and De Luca, L.M. Retinoic acid metabolism and imhibition of cell proliferation: an unexpected liaison. Cancer Res. 56:675-678. 1996.

van der Leede, B., Folkers, G.E., van den Brink, C.E., van der Saag, P.T, and van der Burg, B. Retinoic acid receptor $\alpha 1$ isoform is induced by estradiol and confers retinoic acid sensitivity in human breast cancer cells. Mol. Cell Endocrinol. 109: 77-86, 1995. 
Wan der Leede, B.-J., van den Brink, C.E. Pijnappel, W.W.M, Sonneveld, E., van der Saag, P.T., and van der Burg. B. Auto-induction of retinoic acid metabolism to polar derivatives with decreased biological activity in retinoic acid-sensitive, but not in -resistant human breast cancer cells. J. Biol. Chem. 272:17921-17928, 1997.

Van Wauwe, J.E, Coene, M.-C., Goossens, J., Cools, W., and Monbaliu, J. Effects of cytochrome P450 inhibitors on the in viwo metabolism of all-trans-retinoic acid in rats. J. Pharmacol. Exp. Ther. 252:365-369, 1990 .

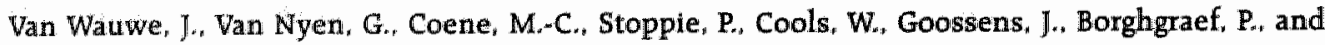
Janssen, P.A.J. Liarozole, an inhibitor of retinoic acid metabolism, exerts retinoid-mimetic effects in vivo. J. Pharmacol. Exp. Ther. 261: 773-779, 1992.

Warrell, R.P.J.. de Thé, H., Wang, Z.Y, and Degos, L. Acute promyelocytic leukemia. N. Eng. J. Med. 329:177-189. 1993.

White, J.A., Guo, Y-D., Baetz, K., Jones, B., Dilworth, F.J., Jones, G., and Petkovich, M. Identification of the retinoic acid-inducible all-trans-retinoic acid 4-hydroxylase. J. Biol Chem. 271: 29922-29927, 1996.

Widschwendter, M. Daxenbichler, G. Dapunt, $O$., and Marth, $C$. Effects of retinoic acid and $\gamma$ interferon on expression of retinoic acid receptor and cellular retinoic acid-binding protein in breast cancer. Cancer Res. 55: 2135-2139, 1995.

Wlliams, J.B., Shoelds, C.O., Brettel, L.M.* and Napoli, J.L. Assessment of retinoid induced differentiation of $F 9$ embryonal carcinoma cells with an enzyme-linked immunoadsorbent assay for laminin: statistical comparison of dose-responce curves. Anal. Biochem. 160: 267-274, 1987.

Wouters, W., van Dun, J., Dillen, A., Coene, M.-C., Cools, W., and De Coster, R. Effects of hiarozole, a new antitumor compound, on retinoic acid-induced inhibition of cell growth and on retinoic acid metabolism in MCF-7 human breast cancer cells. Cancer Res. 52: 2841-2846, 1992. 



\section{Summary}

Retinoids are a group of natural and synthetic compounds that share structural and/or functional similarity to vitamin $\mathrm{A}$. The most active naturally occurring retinotd is probably all-trans-retinoic acid (ATRA). ATRA is known to inhibit proliferation and to induce differentiation of cancer cells. Therefore, the use of ATRA in the treatment of cancer has been explored extensively. Unfortunately, its use as an anticancer drug in differentiation therapy has shown only limited clinical success. One major drawback in the use of ATRA is the prompt emergence of ATRA resistance, believed to be caused by increased ATRA metabolism. One way to tackle this problem is to develop inhibitors of ATRA metabolism that could increase endogenous levels of ATRA. thereby exerting antitumoral responses. Liarozole-fumarate has recently been identified as an inhibitor of ATRA metabolism that might prove valuable in the treatment of cancer (Chapter 1).

To find support for the hypothesis that liarozole-fumarate, besides enhancing the antiproliferative activity of ATRA. can also enhance the differentiation-inducing capacity of ATRA its effect was studied in the breast cancer cell line MCF-7 (Chapter 2). It is shown that liarozole-fumarate enhances the ATRA-induced structural remodelling of cytoskeletal proteins. cytokeratins and actin, as well as of the cell-cell adhesion molecule E-cadherin. Upregulation of E-cadherin expression by ATRA is enhanced by liarozole-fumarate, suggesting that the drug can also enhance the differentiation-inducing capacities of ATRA. 
The effect of liarozole-fumarate was also studied in a well-known and generally accepted model for cellular differentiation. i.e. F9 mouse teratocarcinoma cells (Chapter 3). In these cells, liarozole-fumarate enhances the ATRA-induced expression of well-characterized differentiation markers, such as laminin, collagen IV and cytokeratins. Concomitantly. liarozole-fumarate inhibits ATRA metabolism in these cells, linking its enhancing effects on ATRA-induced differentiation to inhibition of ATRA metabolism. Together, these data show that liarozole-fumarate enhances both the antiproliferative and the differentiation-inducing activity of ATRA by inhibiting ATRA metabolism.

In order to further finetune the mechanism of action of liarozole-fumarate, its effect was studied on the metabolites and isomers of ATRA. These studies could only be properly carried out in a steroid-and retinoid-free cell culture medium. Under these culture conditions cells are growth-arrested and can be restimulated to proliferate by the addition of well defined growth factors. Despite the stimulated cell proliferation, bromodeoxyuridine-immunosignals (a measure for cell proliferation) are barely detectable. Chapter 4 describes an amplification method using fluorescein-labeled tyramide to specifically enhance these weak bromodeoxyuridine-immunosignals.

In Chapter 5 it is shown that not only ATRA itself but also its catabolites, 4-oxo-ATRA and 5.6-epoxy-ATRA, as well as its stereoisomers, 9-cis-RA and 13-cis-RA, show siginificant antiproliferative activity in MCF-7 human breast cancer cells. However, since these catabolites and stereoisomers are formed from ATRA only to a limited extent. these results suggest that the parent compound ATRA itself is mainly responsible for its antiproliferative activity. The antiproliferative activity of the ATRA catabolites, but not of the ATRA stereoisomers. can be enhanced by liarozole-fumarate (Chapter 6). Together, these results suggest that liarozole-fumarate acts as a versatile inhibitor of ATRA metabolism, in that it not only inhibits the breakdown of ATRA but also of the ATRA catabolites.

In Chapter 7 it is discussed that catabolism of ATRA represents an inactivation pathway and that inhibition of this inactivation by liarozole-fumarate might prove valuable as a new alternative in differentiation therapy of cancer. 


\section{Samenvatting}

Retinoïden zijn een groep van natuurlijke en synthetische stoffen die structureel en/of functioneel lijken op vitamine A. Het meest actieve retinoild dat in de natuur voorkomt. is waarschijnlijk all-trans-vitamine A zuur (ATRA). ATRA inhibeert de proliferatie van kankercellen en induceert differentiatie in deze cellen. Daarom is het gebruik van ATRA als een antitumorale stof zeer uitgebreid onderzocht. Helaas vertoont ATRA slechts een beperkte werking als antitumorale stof in differentiatietherapie. Eén probleem bij het klinisch gebruik van ATRA, is het snelle optreden van resistentie tegen ATRA zelf. De meest aanvaarde reden voor het ontstaan van deze resistentie is een versnelde afbraak van ATRA. waardoor het zijn gunstige werking niet meer kan uitoefenen. Eén manier om dit probleem aan te pakken, is de ontwikkelng van inhibitoren om de afbraak van ATRA tegen te gaan. Zulke inhibitoren zouden endogene ATRA-spiegels kunnen verhogen en zo een antitumorale werking uitoefenen. Liarozole-fumaraat werd recent geidentificeerd als een inhibitor van ATRA-metabolisme die beloftevol blijkt voor de behandeling van kanker (Hoofdstuk 1).

Om de hypothese te testen dat liarozole-fumaraat ook de differentiatie-inducerende werking van ATRA kan versterken, werd zijn effect bestudeerd in de humane borstkanker cellijn MCF-7 (Hoofdstuk 2). Liarozole-fumaraat versterkt de structurele veranderingen die veroorzaakt worden door ATRA. Niet alleen eiwitten van het cy toskelet, zoals cytokeratines en actine, ondergaan structurele veranderingen, maar ook de cel-cel adhesiemolecule 
E-cadherine, Deze verhoging van E-cadherine expressie onder invloed van ATRA wordt versterkt door liarozole-fumaraat, hetgeen er op duidt dat liarozole-fumaraat ook de differentiatie-inducerende eigenschappen van ATRA kan versterken. Het effect van liarozolefumaraat werd nagegaan in een goed gekarakteriseerd model voor differentiatie. namelijk F9-teratogene tumorcellen van de muis (Hoofdstuk 3). In deze cellen versterkt liarozolefumaraat de expressie van differentiatiemerkers zoals laminine, collageen type IV en cytokeratines, die door ATRA geïnduceerd worden. Tegelijkertijd inhibeert liarozole-fumaraat het metabolisme van ATRA. Tezamen duiden deze gegevens erop dat liarozole-fumaraat zowel de antiproliferatieve als differentiatie-inducerende werking van ATRA versterkt door inhibitie van het ATRA-metabolisme.

Om het werkingsmechanisme van liarozole-fumaraat verder te ontrafelen, werd het effect bestudeerd op metabolieten en isomeren van ATRA. Deze studies konden enkel uitgevoerd worden in een celkweekmedium dat geen steroïden of retinoïden bevatte. Onder deze kweekcondities stoppen de cellen echter met delen, maar kunnen wel weer tot proliferatie gestimuleerd worden door groeifactoren toe te voegen. Ondanks de gestimuleerde proliferatie, blijven de bromodeoxyuridine immunosignalen (een maat voor celproliferatie) nauwelijks detecteerbaar. Hoofdstuk 4 beschrijft een methode om deze zwakke immunosignalen te versterken, waarbij gebruik gemaakt wordt van tyramide dat gelabeld is met een fluorescerende stof.

In Hoofdstuk 5 wordt aangetoond dat niet alleen ATRA zelf maar ook zijn katabolieten. 4-oxo-ATRA en 5.6-epoxy-ATRA, alsook zijn stereoisomeren, 9-cis-RA en 13-cis-RA, de proliferatie van MCF-7-cellen kunnen inhiberen. Aangezien echter deze katabolieten en stereoisomeren in beperkte mate gevormd worden vanuit ATRA, suggereren deze resultaten dat vooral ATRA zelf verantwoordelijk is voor zijn antiproliferatieve werking. Liarozole-fumaraat kan de antiproliferatieve werking van de katabolieten versterken maar niet van de isomeren (Hoofdstuk 6). Dit wijst erop dat liarozole-fumaraat een veelzijdige inhibitor is, die niet alleen het metabolisme van ATRA inhibeert maar ook de verdere afbraak van de katabolieten van ATRA.

In Hoofdstuk 7 wordt bediscussieerd dat het katabolisme van ATRA leidt tot een inactivatie en dat inhibitie van deze inactivatie door liarozole-fumaraat waardevol kan zijn als een nieuw alternatief voor differentiatietherapie van kanker. 


\section{Dankwoord}

Promoveren is geen solo-aangelegenheid. Ik heb de afgelopen vier jaar het geluk gehad om samen te werken met een aantal zeer bekwame mensen. Dit proefschrift is er dan ook gekomen door jullie hulp. Aan allen bedankt.

In 1993 begon het allemaal met mijn promotor Prof. dr. M. Borgers. Beste Marcel, bedankt dat u me bij de Janssen Research Foundation hebt binnengeloodst en voor het vertrouwen dat $\mathbf{u}$ me schonk om mijn eigen weg te gaan.

Als assistent in opleiding kwam ik terecht bij de vakgroep Moleculaire Celbiologie \& Genetica onder leiding van Prof. dr. E.C.S. Ramaekers, mijn promotor. Beste Frans, onze werkbesprekingen waren steeds grensoverschrijdend en enorm waardevol. Steeds weer keerdle ik terug met een duw in de goede richting en vol goede moed. Ook bij het schrijfwerk was u steeds een grote hulp. U bekeek de dingen soms vanuit een totaal andere invalshoek, de betere, ook al bracht die dan weer veel herschrijfwerk met zich mee. Bedankt Fransl Mijn co-promotor Dr. G. Smets zorgde voor het uitstippelen van de onderzoekslijn. Beste Gerda, het is niet mogelijk om op enkele regeltjes mijn enorme dank neer te schrijven voor de perfecte doctoraatsopleiding die u me hebt gegeven. Onze discussies en uw ontelbare suggesties zorgden ervoor dat ik op het goede spoor bleef. U leerde me naast artikels schrijven nog zoveel meer. Bedankt Gerda!

Voor het praktische werk wil ik Benoit Xhonneux en Hélène Bruwiere bedanken voor hun 


\section{Dankwoord}

inzet en hun enthousiasme. Lieve Dillen en haar medewerkers stonden steeds klaar voor de HPLC-analyses. Lambert Leijssen en zijn medewerkers zorgden voor de figuren van de publicaties en woor de posters. De collega"s van de afdeling oncologie zorgden voor een aangename werksfeer en droegen ertoe bij dat ik steeds met veel plezier kwam werken. Aan hen allen, bedankt?

Ook wil ik iedereen van de afdeling Moleculaire Celbiologie \& Genetica te Maastricht bedanken voor de gasturijheid als $\mathrm{k}$ weer eens even kwam binnenvliegen. In het bijzonder wil ik Jannie. Helma en Gert bedanken voor de experimenten die we samen gedaan hebben en omdat $i k$ steeds welkom was bij jullie thuis als ik wat langer in Maastricht verbleef. Daamaast wil ik in het bijzonder Inge, mijn ouders, mijn broer Danny, mijn schoonouders en de rest van de familie bedanken voor hun steun en interesse die ze steeds toonden voor mijn werk. Mijn vrienden zorgden ervoor dat ik naast het werk genoeg ontspanning kreeg. Bedankt Danny voor de schitterende lay-out en ik hoop dat ik je niet al te veel stress bezorgd heb met de deadlines en het vele verbeterwerk. Jouw stelling: "Ik haat doctoraten!" kan ik echter niet delen. Bedankt mama en papa voor de jarenlange steun en de kansen die jullie me geboden hebben.

En tenslotte Inge, dankjewel voor alles. 


\section{Curriculum vitae}

Jimmy Van heusden werd geboren op 27 april 1971 te Wilrijk. Na het behalen van zijn diploma middelbaar onderwijs aan het Xaveriuscollege te Borgerhout in 1989. begon hij aan het Rijksuniversitair Centrum te Antwerpen zijn universitaire opleiding Scheikunde van 1989 tot 1991 . Van 1991 tot 1993 vervolgde hij zijn opleiding aan de Universitaire Instelling te Antwerpen met de studie Biochemie en behaalde daar het diploma van licentiaat in de Wetenschappen.

In oktober 1993 werd hij aangesteld tot assistent in opleiding bij de vakgroep Moleculaire Celbiologie \& Genetica (promotores: Prof. dr. F.C.S. Ramaekers, Prof. dr. M. Borgers en copromotor: Dr. G. Smets) aan de Universiteit van Maastricht. Het project werd gefinancierd door de Janssen Research Foundation. waar ook het in dit proefschrift beschreven onderzoek werd uitgevoerd.

Vanaf 1 oktober 1997 is hij werkzaam als onderzoeker op de afdeling Oncologie (Dr. W. Wouters) van de Janssen Research Foundation. 